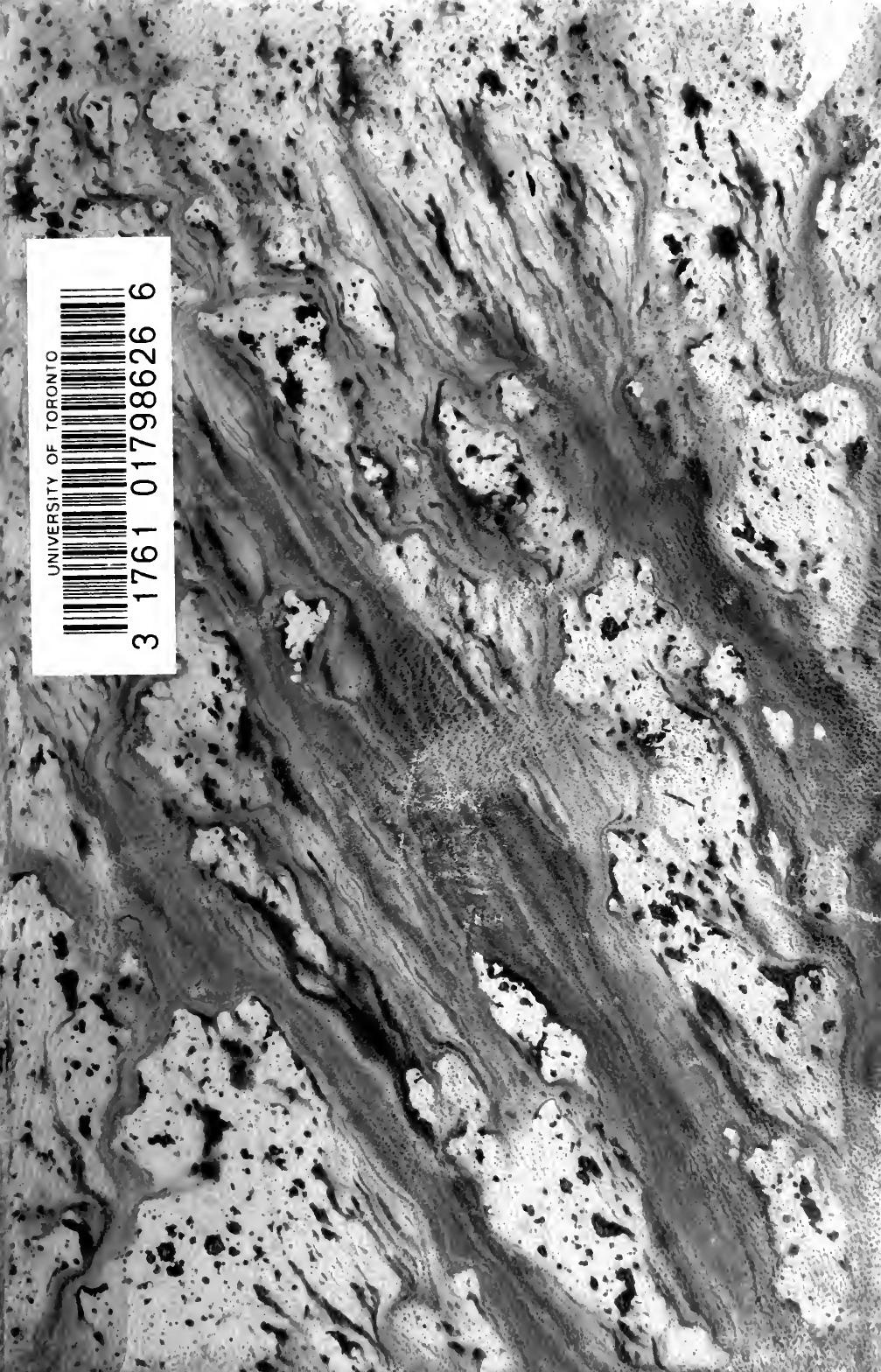






\section{COLECCION DE LIBROS}

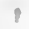

$$
\text { QUE }
$$

XRAXAN DOE AMMÉRXCA RAROS O CURIOSOS

\section{IOMMO SEGTINDO}




\section{TIRADA 500 EJEMPLARES}




\title{
NUEVO DESCUBRIMIENTO
}

\author{
DEL
}

\section{GRAN RIO DE LAS AMAZONAS}

\author{
POR EL
}

\section{P. CHRISTOVAL DE ACUÑA}

Reimpreso según la primera edicion do 1641

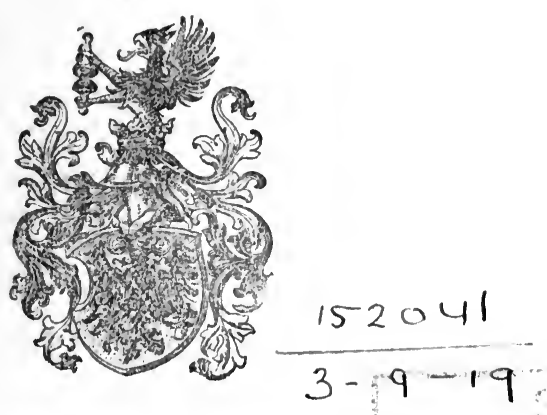

IALIDETIO 1801 


$$
\begin{aligned}
& F \\
& 2546 \\
& A 38 \\
& 1891
\end{aligned}
$$




\section{NOTICIA BIOGRÁFICA}

DE EL PADRE CRISTOBAL DE ACUÑA

$$
+0+
$$

« Nació en Burgos, en $\mathrm{r}_{597}$, de una familia noble é influyente de esta ciudad; llamado por el estado eclesiástico, ingresó en la Compañía de Jesús en r6r2, en el colegio que los padres fundaron allí protegidos por los obispos y después por la familia de los Sanvítores, que adquirió el patronato de la Capilla Mayor.

„Recibidas por Acuña las órdenes sagradas, fué enviado á las misiones de América para Chile y el Perú, siendo después nombrado profesor de Teología moral del colegio de Cuenca (de Quito) en aquel virreinato, y confiándosele más tarde el cargo de rector de aquella casa.

„Designado por la Audiencia de Lima, 
en unión del P. Andrés de Artieda, para que acompañase al general Pedro Texeira en la exploración del rio de las Amazonas, embarcóse en Quito por el mes de Febrero de r639, llegando á Pará en Diciembre del mismo año.

„En esta expedición científica estudió deta. lladamente las costumbres de los pueblos indígenas, haciendo curiosas observaciones que le sugirieron ideas sobre los medios que propuso, de asegurar la dominación sobre aquellos países.

„En otra ocasión practicó otro reconocimiento del curso del rio Napo.»

En el año 1640 regresó á España y presentó al Rey la obra que publicamos, acompañada del Memorial que va al fin, en que da cuenta de las ventajas que pudiera reportar á la monarquía española la conquista y conversión de tanras y tan̊ dilatadas provincias de bárbaros. - " "Pocó tiempo después hizo un viaje á Roma en calidad de procurador de su provincia; á su vuè̀ta se le nombró calificador de la suprema In quisición.

„Permaneció en la corte algún tiempo y yolvió á partir para las Indias Occidentales, como entonces se llamaba el nuevo continente; fijó su residencia en Lima y allí falleció en el año $x 675 . n$ 
Los anteriores datos están tomados de la obra Intento de un diccionario biografico y bibliografico de autores ae la provincia de Burgos, por D. Manuel Martínez Añibarro y Rives; obra premiada por la Biblioteca Nacional. - Madrid, $\mathbf{1} 890$.

\section{$* *$}

Don Marcos Jiménez de la Espada, en los excelentes preliminares con que en $x 880$ ilustró la publicación del manuscrito, de autor anónimo, titulado Viaje del capitán Pedro Texeira, aguas arriba del rio de las Amazonas (I638-39); trae algunas noticias referentes á personajes citados por el Padre Acuña, y copiándola de Antonio de León Pinelo, dice que antes de publicar la relación extensa, dió el mismo Padre Acuña otra á luz, muy breve, la cual califica de rarísima.

Es probable que Pinelo se refiriese al $\mathrm{Me}$ morial que va al fin de este volumen, pues efec. tivamente se debió publicar en Madrid, sin año de impresión, antes de publicarse con el libro.

En el Catalogue Raisonné d'une precieuse collection de livres... sur L'Amerique...-Redigé por Ch.Leclerc. París, MDCCCLXVII.-Pág. 4, se cita dicho Memorial como obra independiente del libro extenso. 
Reimprimimos esta obra porque es rara y porque contiene noticias y descripciones de los indios ribereños del Amazonas, y de las tribus á él circunvecinas, que creemos son del mayor interés.

Con asombro hemos leído en el Diccionario Enciclopédico que publica en Barcelona la casa editorial Montaner y Simón: «El padre Manuel Rodríguez publicó en $\mathrm{r} 684$ un libro titulado $E l$ Marañón y Amazonas y que no es otra cosa que la obra del padre Acuña reproducida puntualmente ó copiada ad peáein litere» (I)

Esta noticia no puede ser más errónea, pues la obra del padre Rodríguez contiene 444 páginas, en folio, y la del padre Acuña la forman solo 46 hojas, por lo que resulta que sería imposible reproducirla literalmente.

En la Biblioteca Nacional existen ejemplares de las dos obras.

Al publicar ahora de nuevo esta obra no hemos suprimido ni una sílaba del texto que contiene la primera edición.

(I) Tomo I. pág. 397, col. I 


\section{NOTICIA BIBLIOGRÁFICA}

DE LAS EDICIONES QUE SE HAN HECHO DE ESTA

OBRA EN DIVERSOS IDIOMAS

$$
\rightarrow 0+
$$

Primera.-Nuevo descubrimiento del gran rio de las Amazonas, por el Padre Cristobal de Acuña, Religioso de la Compañía de Jesús y calificador de la suprema general Inquisición. Al cual fué y se hizo por la provincia de Quito en los reinos del Perú. Al Excmo. Sr. Conde Duque de Olivares. (Cliché con el escudo de la Compañía.) Con licencia en Madrid, en la imprenta del Reino, año I64I. - Un volumen en cuarto, con 6 hojas de preliminares y 46 para las relaciones y el memorial. Rara.

Segunda.-En Madrid I659, citada por Wat. No hay noticia de ningún ejemplar. 
Tercera.-Relation de la riviere des Amazones traduit de 1 espagnol du P. Christophe de Acuna, avec une disertation curiosse sur cette riviere pour servir de preface por M. Feu de Gombervílle. París, Claude Borbin, I682.Cuatro volúmenes en $12^{\circ}$. Tradución muy buscada.

Cuarta.-Relation de la riviere des Amazones. París, chez la veuve Lauis Billaíne, r684.-Cuatro volúmenes en $\mathrm{I} 2^{\circ}$. Esta edición solo se diferencia de la anterior en las portadas.

Quinta.-A relation of the great river of the Amazons in south America; London 1698.-En cuarto. (Brunet.)

Sexta.-... en Wienn. P. Straub, I 729. Traducción hecha al alemán por un padre jesuíta y publicada en unión de la Relación historial de las misiones de los indios que llaman chiquitos, por el P. Juan Patricio Fernández.

Estas son las ediciones de que tenemos noticia que se ha impreso íntegra la obra, ahora nuevamente reimpresa.

En la obra del P. Manuel Rodríguez El Marañón y Amazonas: Madrid, r684, entre las páginas ror á r4I se incluye casi por completo.

El Sr. Martínez Añibarro en su obra citada, dice que de los datos del P. Acuña se sirvió el 
astrónomo M. de la Condomíne para su Rela. tion abnegeé d'un voyage fait dans l'interieur $d^{6}$ L'Amerique Meridionale. París 1745.

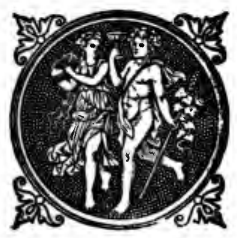





\section{REPRODUCIMOS}

á continuación la portada de la primera edición reducida á la mitad del tamaño del original. 



\section{NVEVO}

\section{DESCVBRI M I EN T O}

DEL GRAN RIO DE LAS

\section{AMAZONAS}

POR EL PADRE CHRSTOVAL

de Acuña, Religiofo de la Compañia de Iesus, y Calificador de la Suprema

General Inquificion

al qual fve, y se hizo por orden

de fu Mageftad, el año de r639

por la provincia de Qvito

en los Reynos del Perú

Al Excelentísimo señor conde

Duque de Oliuares

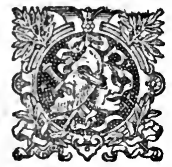

Con licencia; en Madrid, en i a Imprenta del Reino, año de I 64 I 

AL EXCELENTISIMO SEÑOR

CONDE DVQVE DE OLIUARES

$+0+$

A quien (Señor) debemos acudir, con este nueuo mundo descubierto; sino al que en sus hombros, por aliviar los de su dueño, susten. tara gustoso, si pudiera todo lo restante dél? Qué otro Atlante no se rindiera á tamaña car. ga; sino el que con esfuerço más que varonil, há echado el pecho, á mayores, y desmedidos pesos? Quien por celoso que se ostente de los acrecentamientos de su Rey; no se retirara, re. zelando nueuas dificultades; sino el que quanto mayores, más las apetece, para que más luzca su amor, más su fidelidad? Y quién, para decirlo de vna uez, sino el Excelentissimo Se. ñor Conde Duque, podrá patrocinar tan grandiosa empressa, de que depende la conuersion 
de infinitas almas, el acrecentamiento de la Real Coroná, y la defensa, y guarda de todos los tesoros del Perú?

En manos, pues, de V. Excelencia ofrezco este nueuo descubrimiento del gran Rio de las Amazonas, á que por orden de su Magestad fuí, con cuydado, auerigié, y con toda puntualidad recopilé en breues hojas, siendo digno de volúmenes enteros: para que añadida esta preciosa piedra á la Corona de nuestro gran Rey Felipe Quarto que Dios nos guarde, por tan sublime Artífict; mejor assiente, mas luzga, y para siempre permanezca.

Bien puede V. Excelencia aceptar el ofrecimiento, seguro de que es en todo grande, y más de lo que sin duda parece, que á no ser así, ni yo le ofreciera, ni mereciera aceptacion de tales manos. Porque si el dilatado Imperio de Etiopía, se alça con tan glorioso renombre, por ocupar su jurisdiccion espacio de nouecientas leguas: Si la gran China, por encerrar en dos mil de cyrcuito, quince diferentes Reynos, espanta al mundo su grandeza. Y si la longitud que del Perú se publica, se reduze á términos de mil y quinientas leguas, que se miden desde el nuevo Reyno de Granada hasta los vltimos fines del de Chile. Con quanta más razon adquirirá sobre todo lo descubier- 
to, título de grande, el Rio de las Amazonas, pues en el espacio de casi quatro mil leguas de contorno, encierra más de ciento y cinquenta Naciones de lenguas diferentes, suficiente cada vna de ellas á hazer por sí sola vn dilatado Reyno, y todas juntas vn nueno y poderoso Imperio, que fauorecido, y amparado, á la sombrà de V. Excelencia podra parecer grande en los ojos de su Magestad, á cuyos piés, y los de V. Excelencia ofrezco, para esta conquista mi persona, y las de otros muchos de mi Religion, si de nosotros se quiere seruir V. Excelencia, cuya vida prospere el Cielo, con los aumentos, que su persona, celo y fidelidad merecen.

De V. Excelencia criado.

Christoual de Acuña.

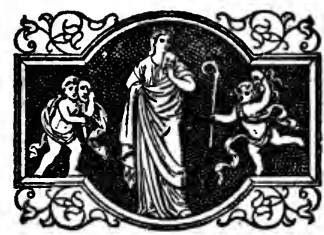





\section{AL LECTOR}

$+000+$

Nacieron (curioso lector) tan hermanadas en las cosas grandes, la nouedad y el descrédito, que no parecen sino gemelos de un parto; $y$ que por el mesmo caso que en lo nueuo, repara con cuydado, la admiracion; peligra el crédito en el ascenso de los más acordados. Y aunque es verdad, que la eficacia de la curiosidad natural, nos inclina á saber nouedades, la incertidumbre de su puntualidad, priua el entendimiento, del mayor deleyte, de que sin duda gozara, si persuadido de lo cierto depusiera toda perplexidad en lo dudoso.

Deseando, pues, sacar á vista de todos, el nueuo descubrimiento del gran Rio de las Amazonas (á que por orden de su Magestad fur, como despues verás) y teménndome, de que aun. 
que por lo nueuo, sería apetecido; con todo no dexaría de padecer rezelos, en lo puntual, quise asegurarte lo vno y lo otro.

Lo primero, con prometerte vn nueuo mundo, Naciones nueuas, Reynos nueuos, ocupaciones nueuas, modo de viuir nueuo, y para dezirlo, en vna palabra, vn Rio de agua dulce nauegado por más de mil y trescientas leguas, todo desde su nacimiento hasta su fin, lleno de nouedades.

Lo segundo, con ponerte delante de los ojos las obligaciones de mi persona, de Religioso de la Compañía de Iesus, de Sacerdote, de Legado de su Magestad, y otras, que ni á tí te importa el saberlas, ni á mí el dezirlas: y si con todo esto te persuadieres, á que la aficion de lo que con algun cuydado trabaje, me adelanta; oye á los que de afuera, con testimonios jurados, acreditan esta Relacion. Vale.

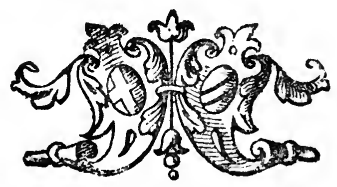




\section{CERT IFICACION}

DEL CAPITAN MAYOR DESTE DESCUBRIMIENTO

Pedro Texeira

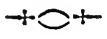

Pedro Texeira, Capitan Mayor al presente en esta Capitanía del gran Pará, y Cauo que fué de la gente de guerra, que fué en el descubrimiento del Rio de las Amazonas, de ida, y buelta, hasta la ciudad de San Francisco del Quito, en los Reynos del Perú.

Certifico, y afirmo con juramento, por los Santos Evangelios, que es verdad, que por orden de su Magestad, y por particular prouision" despachada por Real Audiencia de Quito, vino en mi compañía desde dicha Ciudad, hasta la del Pará, el Reuerendo Padre Christoual de Acuña, Religioso de la Compañía de Iesus, con su compañero el Reuerendo Padre Andrés de 
Artieda, en el qual viage, cumplieron entrambos así en lo tocante al seruicio de su Magestad, á que eran inuiados, como buenos, y fieles vasallos suyos, notando, $\mathrm{y}$ aduirtiendo todo 10 necesario para dar entera y cumplida cuenta del descubrimiento, á que se deue dar entero crédito, mejor que á otro ninguno, de los que fueron en la dicha jornada. $Y$ en lo tocante á las obligaciones de su Abito, y seruicio de Dios, acudieron siempre, como acostumbran los de su Religion; predicando, confesando, y doctrinando á todos los del exército, componiéndoles con sus dudas, amistándoles en sus rencillas, animándoles en sus trabajos, y pacificándoles en sus discusiones, como verdaderos. padres de todos; pasando las mismas incomodidades y trabajos, que qualquiera de los soldados particulares, así en la comida como en todo lo demás.

Y no solo hicieron los dichos padres esta jornada á su costa, sin que su Magestad les diese algun socorro para ella, sino que antes, todo lo que ellos traían, así de sustento, como de medicinas, era comun de todos los necesitados, á quienes acudieron siempre con muy grande caridad, y amor.

$\mathrm{Y}$ por ser verdad todo lo aquí contenido, 
di esta certificacion, firmada de mi mano y sellada con el sello de mis armas.

En esta ciudad de Pará á tres de Março de mil y seiscientos y quarenta años

El Capitan Mayor,

Pedro Texeira.

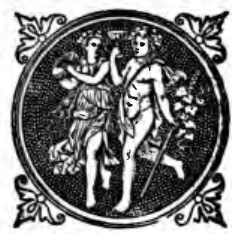





\section{CERTIFICACION}

DEL REUERENDO PADRE COMISARIO DE LAS

MERCEDES

ñon.

Fray Pedro de la Rua, Religioso de nuestra Señora de las Mercedes, Comisario general de mi Orden en los Estados de Marañon, y Pará:

Certifico á todos los que la presente vieren, como los Reuerendos Padres Christoual de Acuña y Andrés de Artieda su compañero, Religiosos de la Compañía de Iesus, uinieron desde laProvincia de Quito, en compañía de la armada Portuguesa, que de buelta del descubrimiento del Rio de las Amazonas, baxó por él hasta la Ciudad del Pará, Costa del Brasil, y Gobierno del Marañon; acudiendo en todo el tiempo que duró el viage, como verdaderos hijos de su religion confesando, predicando, $y$ 
consolando á todos los del ejército, y acudiéndoles en todas sus enfermedades, y necesidades, como verdaderos padres de todos.

Cumpliendo juntamente con lo que por parte de la Real Audiencia de Quito, en nombre de su Magestad, se les auía encomendado en lo tocante á hazer aueriguacion de las cosas principales del dicho Rio de las Amazonas, que hizo el Reuerendo Padre Christoual de Acuña, con el cuydado que se verá por la relacion, á que juzgo se deue dar entero crédito, por ser persona desinteresada, y que solo mouido del seruicio de Dios, y del Rey emprehendió jornada tan trabajosa.

De todo lo qual puedo dar fé, como testigo de vista, que por todo el camino vinimos juntos.

Y por ser verdad dí esta firmada de mi nom bre, y sellada con el sello de mi Religion.

En esta ciudad del Pará, á diez y nueve de Março, de mil y seiscientos y quarenta años.

\section{Comisario}

Fray Pedro de Santa Maria

$y$ de la Rua.

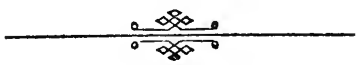




\section{CLAVSVLA}

DE LA PROVISION REAL QUE DIÓ LA AUDIENCIA DE QUITO EN NOMrRE DE SU MAGESTAD, PARA ESTE DESCUBRIMIENTO.

En conformidad de lo qual fué por los dichos mi presidente é Oydores, acordado, que deura mandar dar esta mi carta, y prouision Real, para vos, y cada vno de vos en la dicha razon; é yo he tenido por bien, y os mando, que siendo con ella requeridos, por los dichos Padres Christoual de Acuña y Andrés de Artieda, Religiosos de la dicha Religion de la Compañfa de Iesus, ó por qualquiera dellos, veais los autos suso insertos, y en su cumplimiento, les dareis, $y$ hareis se les de todo el auío breue, y buen pasage que hubieren menester, para el mejor cumplimiento de su mision, viage, buenos efectos que dél espero han de resultar, sin que en ello les sea puesto estorbo, ni impe- 
dimento alguno, por ninguna causa ni razon que sea, pues de lo contrario me tendré por deservido.

Y ruego, y encargo á vos el dicho Padre Christoual de Acuña, que en cumplimiento de $1^{\mathrm{o}}$ proueido por los dichos mi Presidente, y Oydores, y en conformidad del nombramiento en primer lugar en vos fecho por vuestro Prelado y de lo que por su peticion tiene ofrecido. Auiéndoos sido entregada esta mi carta, por parte de dicho mi Fiscal, veáislo en ella contenido, y lo guardeis, cumplais y executeis; y en su cumplimiento, partais desta mi corte con el dicho vuestro compañero, para la dicha Prouincia del Pará, en compañía del Capitan Pedro de Texeira, y demás gente de milicia que con él va, teniendo, como haueis de tener, particular cuydado de describir con la mayor claridad que os fuere posible, la distancia de leguas, Prouincias, poblaciones de lndios, rios y parages particulares, que hay desde la primera embarcacion hasta la dicha Ciudad, y puerto del Pará; informándoos con la mayor certeza que pudiereis dello, para dar bastante noticia, como testigo de vista en mi Real Consejo de las Indias, de todo; y que se tenga la necesaria de las dichas Prouincias, como mando lo hagais, pareciendo personalmente con esta mi carta, 
de parte de la dicha mi Audiencia de Quito, ante los mi Presidente é Oydores del dicho mi Real Consejo: y siendo necesario informar dello á mi Real persona, lo hareis, inuiando relación de todo al Acuerdo de la dicha mi Audiencia de Quito.

Y por vuestra falta el dicho Padre Andrés de Artieda, con el cuydado, y puntualidad, que de vuestras personas, y celo con que los de vuestra Religion acostumbran servirme, confio: y como es negocio tan importante al servicio de Dios nuestro Señor, y nuestro, bien, y conuersion de tantas almas, como se tiene noticia ay en las dichas Prouincias nueuamente descubiertas, Que de lo asi hazer, y cumplir, me tendré de vos, y de la dicha vuestra Religion por bien servido.

Dada en Qnito á veinte y quatro días del mes de Enero de mil y seiscientos y treinta y nueve años.

El Licenciado don Alonso Perez de Salazar. -Doctor don Antonio Rodriguez de San Isidro y Manrique.-El Licenciado don Alfonso de Mesa y Ayala.-El Licenciado don Iuan de Valdés y Llano.-El Licenciado don Gerónimo Ortiz Zapata.-Secretario don Iuan Cornejo.

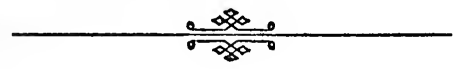





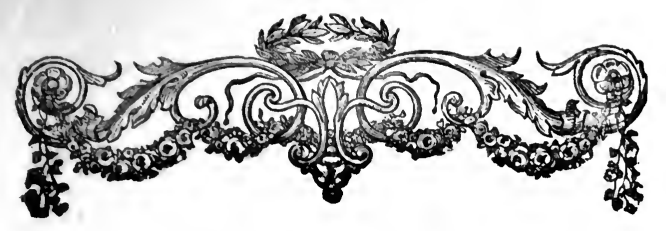

\section{RELACION \\ NVMERO I}

Noticias de este gran Rio

ASI con las primeras vistas de aquella parte de la América, que oy tiene nombre de Perú, Nacieron en nuestra España, aunque por confusas noticias, encendidos deseos de el descubrimiento de el gran Rio de las Amazonas, llamado, por error comun, entre los poco vistos en la Geographia, rio de el Marañon. No solo por las muchas riquezas, de que fué siempre sospechoso; ni por la multitud de gente que mantenian sus orillas, ni por la fertilidad de sus tierras, y temples apacibles de su habitacion, sino principalmente, por entender, con no pequeños fundamentos, que él era la vnica canal, y como calle mayor, que corriendo por el riñon de el Perú, se sustentaua de todas las vertientes que al mar del Norte tributan sus encumbradas cordilleras.

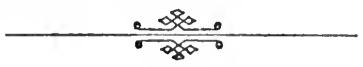




\section{NVMERO II}

Descubre Francisco de Orellana este Rio

STOS deseos solicitaron el coraçon de
Francisco de Orellana, á que el año de mil y quinientos y quarenta, en cierta embarcacion, y con algunos compañeros, se fiase de las corrientes de este gran Rio (que desde entonces, tomó tambien el nombre de Orellana) y pásando á España, por la relacion que de sus grandezas dió, la Cesárea Magestad de el Emperador Carlos Quinto, 1e mandó dar tres Nauios con gente, $y$ todo lo necesario, para que le boluiese á poblar en su Real nombre, á que salió el año de quarenta y nueue, si bien con tan aduersa fortuna, que muriéndose la mitad de los Soldados en las Canarias y Islas de Cabouerde, con los demás que cada dia se le uan disminuyendo, llegó á la boca de este 
gran Rio, tan falto de gente, que le fué fuerça dexar dos Nauios que hasta aquel punto auia conservado, y no se sintiendo con fuerças para más, en dos lanchas de buen porte, que fabricó, con toda su gente, prosiguió sus intentos, entrando el rio arriba, que á pocas leguas reconoció no hauian de tener buen fin; y asi reduciéndose todos á vna sola embarcacion, se retiraron por la Costa de Caracas, hasta dar en la Margarita, adonde acabaron todos, y con ellos las esperanças, de que su Majestad entrase en posesion de lo que tanto se deseaua y en sí prometia.

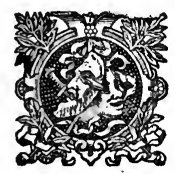




\section{NVMERO III}

Entrapor este rio el tirano Lope de Aguirre

D) OLUIÉRONSE a aviuar estas esperanças veinte años despues, que fué el de quinientos y sesenta, con la entrada que por orden del Virey del Perú hizo á este gran rio el ganeral Pedro de Orsua, arrojándose con buen exercito á sus aguas, para ser testigo de vista de las grandezas, que solo por noticias, se publicauan dél; pero con tan mal suceso, u e ué muerto á trayción por el tyrano Lope de Aguirre, el qual leuantándose no solo por General, sino tamien por Rey, y prosiguiendo el viaje començado, no permitió Dios que acertase á la principal boca, por donde este gran rio desagua en el Occeano, (que desdecia de la fidelidad de Españoles, descubrir vn tirano cosa de tanta importancia á nuestro Rey 
y Señor), sino que dexándose llevar de braços de él, vino á desembocar por la Costa enfrente de la Isla de la Trinidad, en Tierra firme de las Indias de Castilla. Donde por orden de su Majestad le quitaron la vida, y le sembraron las casas de Sal, que oy dia se muestran en aquellas partes.

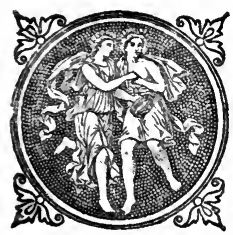




\section{NVMERO IIII}

Intentan otros este descubrimiento

7 STOS mismos deseos de el descubrimiento de este Rio, obligaron al Sargento Mayor Vicente de los Reyes Villalobos, Gouernador y Capitan General de los Quixos, jurixdicion de la Prouincia de Quito, para que se ofreciese con buenos partidos, á principiarle por aquellas partes: en cuya conformidad, despachó la Católica persona de nuestro gran Rey Felipe Quarto, que oy viue, y viua felices años, en el de veinte y vno, vna Cédula á la Real Audiencia, y Chancillería de San Francisco de el Quito, para que se capitulasen las condiciones que para el dicho descubrimiento fuesen convenientes, que por acabar en este interin el dicho Gouernador su oficio, no tuviercn efeto. Como ni tampoco le tuuieron los 
ardientes deseos de Alfonso de Miranda, á quien él sucedió en el cargo, por atajárselos la muerte. Que tambien atajó los luzidos empleos, en que el General Ioseph de Villamayor Maldonado, Gouernador mucho antes que los dos, de el mesmo Gouierno de los Quixos gastó lo mejor de su vida, con ardiente zelo de sugetar á Dios, y al Rey, la multitud de Nacio, nes que confusas noticias, publicauan deste rio: poniendo en execucion por muchas par tes con no pequeños logros sus deseos.

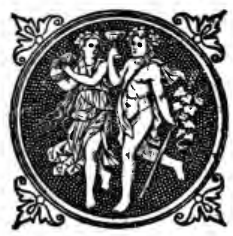




\section{NVMERO V}

Intenta Benito Maciel este descubrimiento

(allitidar Ostos mismos deseos, no solo los ánimos de los castellanos, por las partes de el Perú, sino que estendiéndose á las costas del Brasil, haLitacion de Portugueses, quisieron con el zelo que siempre tienen de aumentar su Corona, començando desde la boca deste rio, buscar su origen, y desentranarle de sus grandezas, á que se ofreció Benito Maciel Pariente, Capitán Mayor que entonces auia sido de el Pará, y al presente Gobernador de el Marañon. En cuya conformidad, se le despachó el año de veinte y seis vna Real Cé. dula, para que lleuase hasta el fin sus intentos, os quales cesaron por querer su Magestad serlvirse de su persona en la guerra de Pernambuco.

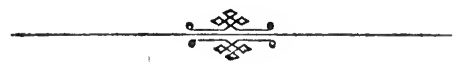




\section{NVMERO VI}

Mandasele a Francisco Coello que haga esta entrada

O parece que se quietaua el coraçon
de nuestro gran Rey hasta ver executada cosa que tanto se deseaua, y ella de sí prometia. $\mathrm{Y}$ aunque se desbaratauan todos los caminos y trazas, que á este fin ordenaua la humana pridencia, no por esto dexaua de insistir en el intento principal, á cuya causa despachó por los años de treinta y tres, ó treinta y quatro, vna Real Cédula, á Francisco Coello de Carauallo, que á la sazon estaua por Gouernador de el Marañon, y Pará, con expreso mandato de que luego se hiciese el dicho des. cubrimiento, y que no auiendo quien imbiar, fuese él en persona á ponerlo en execucion; tanto como esto deseaua su Magestad se efectuase, cosa que por todas partes se intentaua, 
y por ninguna llegaua á deuida execucion, pero tampoco la tuvo en esta ocasion, por no se juzgar el Gouernador con fuerças suficientes para poder diuidirlas, en tiempos que el Olandés infestaua cada dia sus costas. $\mathrm{Y}$ apenas tenia gente para poderle resistir la entrada. Pero no ay que espantarse de que humanas traças, se desbaratasen, quando las diuinas tenian ya dispuesto el modo casi milagroso, con que se auia de hazer este grandioso descubrimiento, que fué como aquí diré:

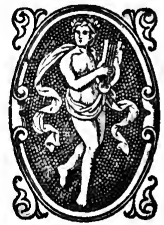




\section{NVMERO VII}

Nauegan este rio dos Religiosos legos de San Francisco

STÁ la ciudad de San Francisco de el Q1) Quito, que es vna de las mas famosas de toda la América, edificada sobre montes, en la más alta Cordillera, que corre por todo aquel nueuo Orbe, aun no medio grado á la vanda del Sur de la línea Equinocial, Cabeça de vna Prouincia, la más fértil, más abundante, más regalada, y de mejores temples que otra ninguna del Perú, y que en multitud de naturales, policía, buena enseñança y Christiandad dellos, á todas se auentaja.

De esta ciudad, pues, por los años de trein. ta $y$ cinco, treinta $y$ seis, y principios del treinta y siete, salieron ciertos Religiosos de San Francisco, por orden de sus superiores en compañia del Capitan Iuan de Palacios, y 
otros Soldados, para proseguir estos en lo temporal, y aquellos en lo espiritual, con el descubrimiento deste rio, que ya más auia de treinta años, principiaron los Padres de la Compañía de Iesus, por los Cofanes, donde los naturales mataron cruelmente al Padre Rafael Ferrer, en pago de la Doctrina que les enseñaua. Llegando, pues, los dichos Religiosos de San Francisco á la Prouincia de los Encabellados, numerosa mucho en gente, pero bien estrecha para el encendido zelo con que estos siervos de Dios, como siempre acostum. bran, la pretendian reducir al gremio de la Iglesia: asistieron entre los naturales algunos meses, y viendo el tiempo que perdian, y que la mies no la tenia aún Dios sazonada, se boluieron vnos á su Conuento de Quito, quedando los otros en compañía de los pocos Soldados que quisieron asistir al lado de su Capitan, que á pocos dias vieron por sus ojos muerto á manos de aquellos à quieřes iuan á hazer tanto bien: con que les fué fuerça desamparar la tierra, y endereçando su viaje á Quito todos los demás, dos Religiosos Legos llamados Fray Domingo de Brieua y Fray Andrés de Toledo, con seis soldados en vna embarcacion pequeña, se dexaron lleuar de la corriente rio abajo, no con otro intento, á lo que se puede 
imaginar, que lleuados del diuino impulso que entre tan flacos instrumentos, tenia librado el primer descubrimiento deste rio.

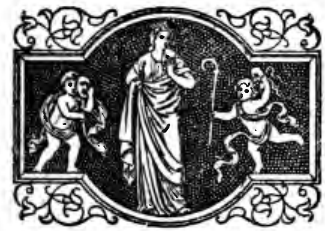




\section{NVMERO VIII}

\section{Llegan los dos Religiosos al Marañon}

\section{AUORECIÓ Dios los intentos de estos dos Religiosos, y despues de muchos}

dias de nauegacion en que experimentaron bien su providencia, llegaron á la Ciudad de el Pará, poblacion de Portugueses, que está situada quarenta lesuas de donde este rio desemboca en el Occeano, jurixdicion de el Gouierno de el Marañon; auiendo pasado sin lesion alguna por inmensas Prouincias de Bárbaros, y muchas dellas Caribes, que comen carne humana, recibiendo de ellos el necesario mantenimiento, para lleuar al fin lo començado. Pasaron luego á la Ciudad de San Luis de el Marañon, donde el Gouernador asistia, que en onces era Iacome Reymundo de Noroña, electo á mi ver, mas por prouidencia diuina, que 
por la voz de el pueblo, pues ningun otro rompiera con tantas dificultades, ni se opusiera á tan contrarios pareceres, que no tuviera el zelo y obligaciones que á él le corrian, de seruir desinteresadamente en este descubrimiento á su Dios, y á su Rey. A este, pues, dieron los dos Religiosos noticia de su viage, que fué como de personas que venian cada dia huyendo de las manos de la muerte, y lo que más pudieron aclarar, fué dezir que venian de el Perú, que auian visto muchos Indios, y que. se atreuerian á boluer por donde auian baxa do, äui endo quien quisiese seguir esta derrota

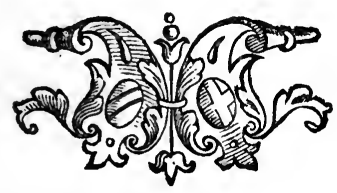




\section{NVMERO IX}

Es nombrado para la conquista Pedro de Texeira

ONFUSO quedaua en este estado nuestro descubrimiento, y mal podia su Magestad tomar resolucion de lo que conuenia á su Real seruicio, si el Gouernador, como ya dixe, no tomara pechos al aclarar estas sombras, y contra el parecer de todos, imbiar gente por el rio arriba, hasta la Ciudad de Quito, que con más atencion y menos rezelos, notasen todo lo que hallasen en él, digno de aten. cion.

Para esta empresa nombró por Cabeça y Caudillo de todos á Pedro Texeira, Capitan por su Masestad de los descubrimientos, persona á quien el Cielo sin duda tenia escogida para esta ocasion, pues sola su prudencia, y sus obligaciones, pudieran acabar lo que él 
trabajó y hizo, en seruicio de su Rey en esta jornada, no sólo con gastos y pérdidas de su hazienda, sino también con mucho dispendio de su salud, si bien nada de esto es cosa nueua, en quien por tantos años que há que sirve á su Magestad, nunca se ha grangeado otros intereses que darhonrada cuenta de todo lo que se le ha encargado, que ha sido mucho, $y$ en ocasiones de no poca importancia.

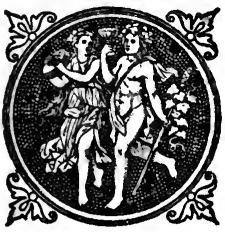




\section{NVMERO X}

\section{Comienfa su viaje Pedro Texeira}

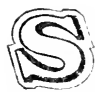

ALIÓ pues este buen Caudillo de los Confines del Pará, á los veinte y ocho de Octubre de mil y seiscientos y treinta y siete años, con cuarenta y siete Canoas de buen porte (embarcaciones de que adelante se dirá) y en ellas setenta Soldados Portugueses, mil y doscientos Indios de boga y guerra, que con las mugeres y muchachos de servicio pasarian todas dẹ dos mil personas. Duró el viage cerca de vn año, así por la fuerça de las corrientes, como tambien por el tiempo, que en hazer mantenimictes para tan numeroso exército, era fuerça se gastase, y principalmente por caminar sin guias ciertas, que les pudiesen endereçar sin rodeos, ni dilaciones, por los rumbos más breues, por los quales deuieran seguir su 
camino por ser este tan cumplido, $y$ por las incomodidades que en él se pasauan, comencaron los Indios amigos á mostrar poco gusto de proseguirle, y de hecho, algunos se boluieron á sus tierras. Rezeloso el Capitan Mayor de que no hiziesen los demás lo mesmo, y le dexasen imposibilitado de proseguir su viage, vsó de industria, ya que rigor, ni fuerça bastaua á conseruar los que estaban titubeando; $y$ aunque se hallaua á la mitad del camino, fingió estar muy propinquo al término, y aprestando ocho canoas bien guarnecidas de bogas, y So!dados, las mandó ir delante, como aposentadoras de lo restante del Exército, y á la verdad, no eran sino descubridoras del mejor camino en que mil vezes dudoso de lo cierto, alucinaban.

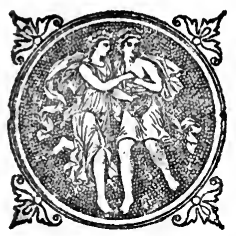




\section{NVMERO XI}

Adelantase el Coronel Benito Rodriguez.

5N OMBRÓ Pedro de Texeira por Cabo 9 desta cuadrilla al Coronel Benito Rodriguez cie Oliuera, hijo del Brasil y persona que como criada toda su vida entre los naturales, les tiene calados los pensamientos y con pequeñas muestras adiuina lo que tienen en el coraçon, con que es conocido, temido y respe. tado de todos los Indios de aquellas Conquistas, y en el presente descubrimiento irrıportó no poco su persona, para llevarle al fin con la felizidad que se hizo. Llegó, pues, el Coronel con su esquadra, despues de vencidas muchas dificultades, al Puerto de Páyamino, dia de San Iuan á los veinte y quatro de Iunio de mil y seiscientos y treinta y ocho, que es la primera habitacion de Castellanos, que por 
aquellas partes, sugeta á la Prouincia de los Quixos, jurixdicion de Quito, se auezinda á las orillas deste gran Rio. Si bien por el de Napo (de que despues se hará mencion) hubiera tenido toda la Armada mejores Puertos, más bastimientos y menos pérdidas, no solo da Indios sino tambien de haziendas.

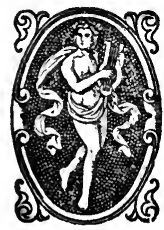




\section{NVMERO XII}

Dexa el Capitan el exercito en los Encabellados

(2) IEMPRE iua siguiendo el Capitan Ma(D) yor los rastros y auisos que su Coronel le dexaua en las dormidas, con que alentados de nueuo, cada dia pensauan, seria el siguiente, el postrero de la jornada. Sustentados con estas esperanças llegaron á vn rio (de que ya diximos arriba) poblado todo de naturales; de paz, en tiempos pasados, pero ya rebeldes por la muerte del Capitan Palacios. Pareció este sitio apacible, para dexar alli situada toda la fuerça de el exército, y nombrando por Capitan y Cabo de todos á Pedro de Acosta Fauela, que con la compañia que llebaua á su cargo, hiciese allí pié fijo hasta tener nuevo orden; quedó tambien con la suya el Capitan Pedro Bayon; personas ambas que bien mostraron en 
esta ocasion, el valor con que tantos años auian exercitado la milicia, y la fidelidad con que obedecian las ordenes de sus mayores, pues á pie quedo esperaron onze meses, sin jamás intentar otra cosa, con ser la tierra enferma, los mantenimientos ningunos, sino los que se buscauan dé2axo de las armas, y esos tan cortos que apenas parece podian ser suficientes á sustentar la vida. Pero bien satisfecho estaua el Capitan Mayor de los que dexaba en semejantes riesgos, que sola la muerte les podria apartar de el cumplimiento de sus órde. nes.

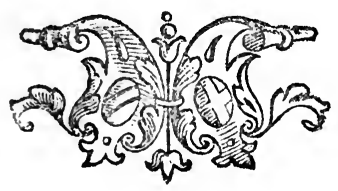




\section{NVMERO XIII}

\section{Llega el Capitan Mayor à Quito}

ON esta confiança, y pocos compañeros, prosiguió Pedro Texeira en seguimiento de su Coronel, que ya halló estaua dias auia en la Ciudad de Quito. Donde fueron bien recibidos y agasajados, asi de lo Secular como de lo Eclesiástico, mostrando todos el gozo que tenian de ver en sus tiempos, y por vasallos de su Majestad, no solo descu. bierto, sino tambien navegado, desde su fin hasta sus primeros principios, el afamado rio de las Amazonas.

No tuvieron la menor parte de estos regocijos, todas las Religiones de aquella Ciudad, que son muchas, y muy autorizadas, ofre ciéndose cada vna por sí, con obreros fieles, que desde luego entrasen trabajando en la 
grande, é inculta viña de inmensos bárbaros, de que por sus nueuos descubrimientos se les daua noticia.

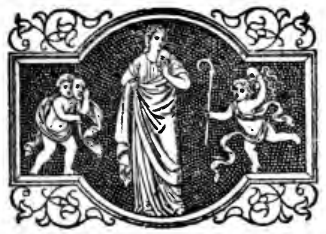




\section{NVMERO XIIII}

\section{Resolucion del Virey del Perí}

\section{ECIBIDA en aquella Real Audiencia}

$\triangle 1$ de Quito la noticia, que bastaua para hazer pleno concepto de lo mucho que á ambas Magestades, Diuina y humana, importaua el acudir luego al buen despacho de negocio tan graue, no se atrauieron los señores Presidente y Oydores de ella à resoluer naḑa, sin primero dar auiso al Virey del Perú, que á la sazon era el Conde de Chinchon. El qual despues de consultado el caso con la gente más práctica de ia Ciudad de Lima, Corte de aquel nuewo mundo, resoluió por carta suya para el Presidente de Quito (que era el Licenciado D. Alonso Perez de Salazar) su fecha á los diez de Nouiembre de seiscientos y treinta y ocho, que el Capitan Mayor Pedro Texeira con toda 
su gente se boluiese luego, por el mesmo camino que auia venido á la Ciudad de Pará, dándoles todo lo necesario para el viaje, por la falta que tan buenos Capitanes y Soldados, $\sin$ duda harian en aquellas fronteras, que tan in. festadas son de ordinario de el Enemigo Olandés, mandando juntamente, que si fuese posible, se dispusiesen las cosas de suerte, que fuesen en su compañía dos personas tales, á quienes se pudiese dar fe por la Corona de Casti. lla, de todo lo descubierto, y de lo demás que á la buelta de viaje se fvese descubriendo.

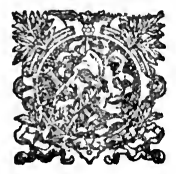




\section{NVMERO XV}

El General D. Iuan de Acuña, se ofrece d la jornada

T $N$ confúsion puso á todos la execucion [1) Jesta vitima orden del Virey, por los muchos inconvenientes, que mirado á prima faz representaua. Si bien no faltaron seculares zelosos del seruicio de su Magestad, que atropellándolo todo deseaua ser cada cval vno de los que se nombrasen para tamaña empresa. Pero el que entre todos se mostró más feruoroso de nueuas ocasiones, en que proseguir en seruicio de su Rey, lo que ya por mas de treinta años él auia hecho, y sus antepasados por toda la vida, fué D. Iuan Vazquez de Acuña, Caballero del Auito de Calatraua, Teniente de Capitan General del Virey del Perú, y Corregidor actual, por su Magestad, de Españoles, y naturales, en la mesma Ciudad de Quito y su 
Comarca, el qual ofrecia, no solo su persona, pero juntamente su hazienda para á su Costa levantar gente, pagar soldados, comprar mantenimientos, disponer pertrechos, y hazer todos los gastos necesarios para tan cumplido viage, solo con el interés que siempre tuvo, de que su Rey y señor fuese seruido. No surtió efeto su buen deseo, por no !e dar licencia quien podía, que atendiendo á la falta que podria hazer, dexando el oficio que exercía actualmente, se le negó. Si bien no quiso Dios que tan honrados deseos quedasen del todo frustrados, disponiendo las cosas de suerte, que ya que él no iua fuese en su lugar el Padre Cristoual de Acuña, Religioso de la Compañáa de Iesus, su hermano; teniendo á gran dicha poder por este modo ofrecer al servicio de su Majestad cosa que tanto estimaba, y le tocaba tan de cerca, lo cual sucedió desta manera:

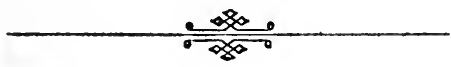




\section{NVMERO XVI}

Nombra la Real Audiencia al Padre Christoual de Acuña para esta jornada.

72 IENDO el Licenciado Suarez de Poa. go, Fiscal de la Real Chancillería de Quito, ya de partida la Portuguesa Armada, y considerando como fiel ministro de su Majestad los muchos vtiles y ningunos inconuenientes que se podian seguir de que doz Religiosos de la Compañía de Iesus, le acompañasen notando con cuydado todo lo digno de aduertencia en este gran rio, con cuya noticia pasasen á España, para dar cierta relacion de todo en el Real Consejo de las Indias, y siendo necesario al Rey nuestro señor en su Real persona. Como lo pensó el Fiscal, así lo propuso en el Real acuerdo, y pareciendo á todos bien la propuesta, se dió noticia dello al Prouincial de la Compañía de Iesus, que á la sa- 
zon era el Padre Francisco de Fuentes, el qual estimando la honra que se hazia á su Religion, en fiar de ella cosa de tanta importancia, y codicioso de que por esta via se le abriese puerta, á que sus hijos entrasen á lleuar la nveva luz del Santo Euangelio, á tanto número de almas, que en este gran Rio, yazen en la sombra de la muerte, nombró en primer lugar, para esta empresa, al padre Christoual de Acuña, Religioso profeso, y actual Rector del Colegio de la Compañia de la Ciudad de Cuenca, jurixdicion de Quito. Y en segundo lugar, y por su compañero, al Padre Andres de Artieda Lector de Teología en el dicho Colegio de la mesma Ciudad de Quito. Aceptado por los señores de aquella Real Audiencia el nombramiento de los dichos dos Religiosos de la Compañía de Iesus, se les mandó dar una Real Provision (cuya cláusula pusimos al principio) en que se les manda, que siendo con ella requeridos, luego al punto partan de la Ciudad de San Francisco del Quito, en compañia del Capitan Mayor Pedro Texeira, y llegando á la del Pará, pasen á España á dar cuenta de todo lo que con cuydado huuieren notado en el dis. curso del viaje al Rey nuestro señor en su Real persona. 


\section{NVMERO XVII}

Salen los Paäres de Quito,

(a) BEDECIENDO luego los dichos Padres lo que se les mandaba, y á los diez y seis dias de Febrero de mil y seiscientos y treinta y nueue, dieron principio á tan luengo viage, que duró por espacio de diez meses, hasta entrar en la Ciudad del Parà donde tomaron puerto á los doce de Diciembre del mesmo año.

Despues de hauer hollado con sus plantas los encumbrados cerros, que con el licor de sus venas, alimentan. y dan el primer sustento á este gran Rio; y caminando sotre sus ondas hasta donde dilatado en ochenta y cuatro leguas de boca, paga caudaloso tributo al mar Occeano; despues de hauer con muy particular cuydado notado todo lo que en él ay digno 
de aduertencia; después de auer marcado sus alturas, señalado por sus nombres los Rios que le tributan, reconocido las naciones que se sustentan en sus orillas. Visto su fertilidad, gozando sus mantenimientos, experimentando sus temples, comunicado con sus naturales, y finalmente despues de no haber dexado cosa de las en él contenidas de que no puedan ser testigos oculares.

Como á tales, pues, como á personas que tantas obligaciones nos corren de ser puntuales en lo que se nos ha encomendado, pido yo á los que esta relacion leyeren, me den el crédito que es justo, pues yo soy el vno dellos, $y$ en nombre y por parecer de entrambos, tomé la pluma para escriuirla.

Digo esto por las que podrá ser saquen otros á luz, quizá no tan ajustadas á la verdad como convenia. Esta lo será, y tanto, que por ningun caso pondré en ella cosa de que no pueda con la cara descubierta atestiguar con más de cinquenta Españoles, Castellanos y Portugueses, que hicieron el mesmo viage, afirmando lo cierto por eierto, y lo dudoso por tal, para que en cosa tan gra ue, y de tanta importancia, nadie se arroje á creer más de lo que en esta relacion se afirma. 


\section{NVMERO XVIII}

El Rio de las Amazonas es el mayor del Orbe

T S el famoso Rio de las Amazonas, que [1] corre y vaña las más ricas, fértiles y pobladas tierras de todo el Imperio del Perú; el que de oy en adelante podemos, sin vsar de hipérboles, calificar por el mayor y más célebre del Orbe. Porque si el Ganges riega toda la India, y por caudaloso oscurece el mar quando desagua en él, haziéndole que pierda el nombre, y se llame Sinu-Gangetico, por otro nombre Golfo de Bengala. Si el Eufrates, por Rio afamado de la Siria, y parte de la Persia, es la delicia de aquellos Reynos. Si el Nilo rieşa lo mejor del Africa, fecundándola con sus corrientes, el Rio de las Amazonas riega más extendidos Reynos, fecunda más Vegas, sustenta más hombres, y aumenta con sus 
aguas mas cauciáiosos úcceanos; sôiô ies fâtî. para vencerlos en felicidad, tener su origen en el Pacifico, como de aquel os lo afirman graues Autores.

Del Ganges dizen las historias, que desaguan en él treinta caudalosos rios y que en sus playas se ven arenas de oro, innumerables rios desaguan en el de las Amazonas, arenas de oro tiene, y tierras riega, que atesoran en sí infinitas riquezas.

El Eufrates se llama así, como notó San Ambrosio, á latificando, porque con sus corrientes alegra los campos, de suerte que los que :iega este año, aseguran äbundante cosecha para el siguiente.

Del rio de las Amazonas se puede afirmar que sus orillas son en la fertilidad Paraisos, y si el arte ayuda á la fecundidad del suelo, será todo él vnos apacibles jardines. La felicidad de la tierra, que riega el Nilo, celebró Eucano en estos versos:

Terra fuis contenta boais, non indiga mercis ant souis; in falo, tanta eft fiducia Nilo.

No necesitan las Prouincias vezinas al Rio de las Amazonas de los extraños bienes; el Rio es abundante de pesca, los montes de ca- 
ça, los aires de aues, los árboles de frutas, los cumpos de mieses, la tierra de minas, y los naturales que le hauitan de grandes hauilidades, y agudos ingenios, para todo lo que les importa, como iremos viendo en el discurso desta historia.

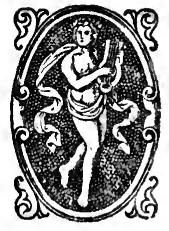




\section{NVMERO XIX}

Nacimiento del Rio de las Amazonas

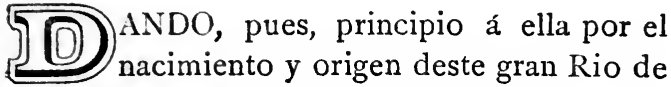
las Amazonas, hasta aora oculto siempre, queriendo cada tierra hazerse madre de tal hijo atribuyendo á sus entrañas los primeros sustentos que le dan ser, nombrándole con nombre de Rio Marañon, error tan asentado en aquellas partes, que la ciudad de los Reyes, Emporio de todas las de América, se gloria dé que las Cordilleras de Guanuco de los Caualleros, á distancia de setenta leguas de su sitio, dan cuna y cortan los primeros pañáles de vna laguna, que allí está, á este afamado Rio $\mathrm{Y}$ á la verdad, no va muy fuera de camino pues ya que no sea este su origen del Rio de las Amazonas, eslo por lo menos de vno de 
los más famosos, que él conuierte en su propia sustancia, y alimentado de sus aguas, co: re más brioso, su carrera.

Quiere taı.ıbien el nuevo Reyno de Granada aumentar su crédito, prohijando á las vertientes del Macóa, el primer nacimiento de este Rio, que en su origen llaman los naturales el gran Caquéta, si bien con ningun fundamento, pues en más de setecientas leguas, no se ves. las caras estos dos Rios, y quando se encuen. tran, como reconociendo á su mayor, torciendo el Caquéta su curso, viene á pagar vasallage al de las Amazonas.

Por otras muchas partes quiere el Perú alçarse con el principio y nacimiento deste gran Rio, celebrándole y festejándole, como á Rey de los demás. Pero de oy en adılante no lo permitirá la ciudad de San Francisco de el Quito, pues á ocho leguas de su asiento tiene encerrado este tesoro, á las faldas de la Cordillera, que diuide la jurixdicion del Gouierno de los Quixos, al pie de dos cerros, llamado el vno Guamaná, y el otro Pulca, distantes entre sí aún no dos leguas, de los quales da este por madre al recien nacido vna grande laguna; y aquel otra, aunque no de tanto box, si bien de mucho fondo, que agujerean . do vn cerro, que inuidioso del tesoro, que de 
sí ofrecia, con la fuerça de un terremoto se le echó encima, pretendiendo ahogar en sus principios tan grandes esperanças, como de aquel pequeño lago se prometian al mundo. Destas dos lag:nas, que caen veinte minutos debaxo de la linea Equinocial á la vanda del Sur, tiene su principio el gran Rio de las Amazonas.

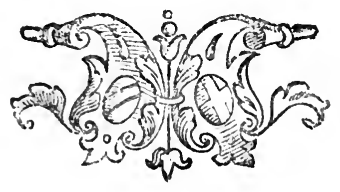




\section{NVMERO XX}

\section{Su curso, latitud y longitud}

20 AZE su curso este Rio, de Oeste, á TLeste, como dize el nauegante, esto es de Poniente á Oriente, vezino siempre á la Equinocial la vanda de el Sur, por dos grados, tres, quatro, cinco, y dos tercios en la mayor altura. Tiene de largo desde su nacimiento hasta que desagua en el mar, mil y trecientas y cinquenta $y^{\prime}$ seis leguas Castellanas, bien medidas, y segun Orellana, mil y ochocientas. $\mathrm{Ca}$. mina siempre culebreando en bueltas muy dilatadas, y como señor absoluto de todos los otros rios que en el entran, tiene repartidos sus braços que son como fieles executores suyos, por medio de los quales sale al encuentro, y cobrando dellos el debido tributo de sus aguas, los buelue á en incorporar en la Canal 
principal. Y es cosa digna de notar, que qual es el guesped que recibe, tales son los A posentadores, que le despacha; de suerte, que con ordinarios braços, recibe los más comunes Rios, acrecentando otros mayores, para los de más quenta; y á algunos que son tales, que casi se lc pueden poner hombro con hombro, él mesmo en persona con toda su corriente les sale á ofrecer el hospedaje. De latitud y anchura es muy vario, porque por vnas partes se esplaya vna legua, por otras dos, y pur otras mucho más, guardando tanta estrechura en tantas leguas, para con más licencia, dilatado en ochenta y quatro de boca, ponerse barba á barba con el mar Occeano.

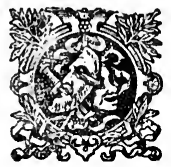




\section{NVMERO XXI}

\section{Estrechura y fondo del Rio}

FT $\mathrm{L}$ mayor estrecho donde este Rio reco[1) ge sus aguas, es de poco más de vn quarto de legua, en altura de dos grados y dos tercios. Lugar sin duda que preuino la diuina Prouidencia, estrechando este dilatado mar dulce, para que en su angostura se pudiese fabricar vna fortaleza que impida el paso á cualquiera Armada Enemiga, por muchas fuerças que trayga, si acaso entrare por la principal boca deste gran Rio; que entrando por el Rio Negro, en el mesmo se aurá de poner la defen. sa. Está esta angostura trecientas y sesenta leguas de la Balsa de donde en ocho dias con embarcaciones ligeras, á vela y remo, se puede Giar auiso mucho antes que el Enemigo les dé vista. 
La profundidad de este Rio es grande, y en partes tal, que no se halla fondo; desde la boca hasta el rio Negro, que es espacio de casi seiscientas leguas, nunca le faltan treinta ó quarenta brazas de altura en la Canal principal; de aí arriba va variando más, ya con veinte, ya con doze, y ya con ocho brazas muy á sis principios, fondos suficientes para cualesquiera embarcacion, que aunque la corriente impida, no faltan de ordinario todos los dias tres, quatro horas de brisas fuertes, y á vezes po: todo el dia con que vencerla.

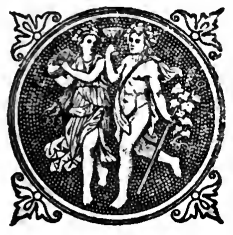




\title{
NVMERO XXII
}

\author{
Islas, y su fertilidad, y frutas
}

voDO este Rio está poblado de Islas,
vnas grandes, pequeñas otras, tantas en número que no se pueden contar, porque se encuentran á cada paso; las ordinarias son de quatro, ó cinco leguas, otras ay de diez, y de veinte; y la que habitan los Tupinambas (de quienes hablaremos despues), tiene rrás de seis leguas de circunferencia; ay tambien otras muchas muy pequeñas que les siruen á los naturales de hazer en ellas sus sementeras, teniendo en las mayores su habitacion. Estas Islas de menor porte, y á vezes las mayores, ó mucha parte dellas, vaña todos los años el Rio, fertilizándolas de suerte con sus lamas, que no pueden jamás alegar titulo de estériles, aunque por muchos años continuados, se les pida el 
ordinario fruto, que es el maiz, y la yuca, ó mandioca, comun sustento de todos, y de que tienen mucha abundancia; y aunque al parecer estaua expuesta á grande disminucion y pérdida, con tan poderosas auenidas, la naturaleza, madre comun de todos, dió á estos Bárbaros medio facil para su conseruacion. Cogen la yuca, que son vnas rayces, de que se haze el cazabe, pan ordinario en todas aquellas Costas del Brasil, y cabando en la tierra vnas cueuas, 6 filos hondos, las sepultan en ellos, de xándolos muy bien tapados todo el tiempo que duren las crecientes, las quales pasadas, las sacan y benef.cian para su sustento, sin que por eso pierdan vn punto de su valor. $Y$ si la naturaleza enseñó á la hormiga á guardar como en trojes en las entrañas de la tierra el grano, que ha de ser alimento suyo todo el año, qué mucho diese traça al Indio, por más bárbaro que sea, para prevenir su daño, y guardar su sustento; pues es cierto que la Diuina Prouidencia más cuida de los hombres que de ios anlmales brutos.

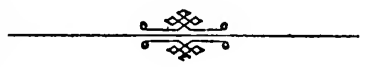




\section{NVMERO XXIII}

Generos de bebidas que usan

\section{TSTE es, como ya dixe, el cotidiano 10 pan, que siempre acompaña las demás} viandas. Y no solo sirue de comida, sino juntamente de bebida, á que son en general muy inclinados todos los naturales, para lo qual hazen vnas grandes tortas delgadas, que cocidas en horno, se auizcochan, de suerte que duran por muchos meses: estas guardan en lo más alto de sus casas para tenerlas libres de las humedades de la tierra, y quando las quieren aprouechar, echándolas en agua las deshazen; y cocidas al fuego, las dan el punto que han menester: reposan este caldo, y frio, es de ordinario vino de que ellos vsan, que á veces es tan fuerte, que como si fuera vino de hu'as, les embriaga, y haze perder el juizio. Con este 
vino celebran sus fiestas, lloran sus mucitos, reciben sus guéspedes, hazen sus sementeras, y las cogen. Y finalmente, no hay ocasion en que se junten, que no sea este el azogue, que los recoge, y la liga que los detiene. Hazen también, aunque no es tan ordinario, otros géneros de vinos, que como tan inclinados a la embriaguez, son como los taures, que nunca les falta de qué echar mano; ellos la echan de qualesquiera fruta silvestre, de que abundan los árboles, que deshechas en agua, la dan con su zumo tal sabor y fuerça, que muchas vezes excede á la cerbeza, bebida tan vsada en todas las Naciones Extranjeras. Guardan estos vinos, vnos en tinajas muy grandes de barro, como las de nuestra España; otros en pipas pequeñas, que labran de vna pieça, de socabados troncos, y otros en vasijas grandes que texen de yeruas dándolas por dentro y fuera tal betun, que no se les pierde gota de !icor que en ellas recogen.

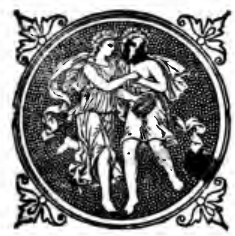




\section{NVMERO XXIIII}

$$
\text { Frutas que tienen }
$$

5 AS viandas que acompañan este pan, y vino, son muchas, no solo de frutas, como Plantanos, Piñas, Guayabas, Auios, Castañas muy sabrosas, que llaman en el Perú Castañas de la Sierıa, y á la verdad más parecen esto, que no aquello, si bien las llaman así por nacer'en vnos cocos que se asemejan al herizo de la Castaña, Tienen Palmas de diuersos géneros, que producen vnas sazonados cocos, y otras sabrosos dátiles, que aunque siluestres, son de muy buen gusto, y otras muchas diferencias de frutas, propias todas de tierras calientes. Tienen tambien rayces de mucho sustento, como son batatas, yuca mansa, que llaman los Portugueses, Macachera, 
Carás, criadillas de tierra, y otras que asadas, ó cocidas, no solo son tan gustosas, sino sustanciales.

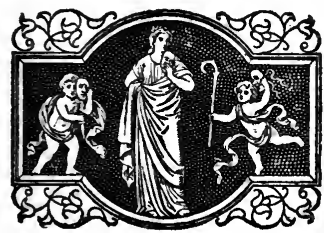




\section{NVMERO XXV}

Pescados de este Rio y del Pegebuey

ON todo, de lo que más se alimentan, y lo que como dizen, les haze plato, es el inmenso pescado, que con increible abundancia cada dia cogen á mános llenas deste Rio. Pero entre todos, el que como Rey se señorea y está poblado en todo el Rio, desde sus primeros principios hasta que desagua en los mares, es el Pegé̂uey, pescado que el gusto solo le queda el nombre de tal, pues no ay persona que quando le come no le tenga por sazonada carne; es tan grande como vn bezerro de año y medio, y en la cabeça, á tener astas, y orejas, no se diferenciara dél; tiene por todo el cuerpo algunos pelos, no muy largos, á modo de cerdas blandas, y muévese en el agua con dos braços cortos, que en forma de palas le siruen de remos, debaxo de los quales mues- 
tra la hembra sus pechos, cou que mantiene con leche los hijos que pare.

Del cuero, que es muy grueso, hazen adargas los guerreros, tan fuertes, que bien curado, no le pasa vna bala de arcabuz.

Susténtase este pescado solo de yerua que pace, como si fuera buey verdadero, de donde cobra su carne tan buen gusto, y es de tanta sustancia, que con pequeña cantidad queda vna persona más satisfecha, y con más fuerças que si comiera doblado de carnero.

Debaxo del agua detiene poco el resuello, y así donde quiera que anda, saca á menudo el ocico para cobrar nuevo aliento, de donde le viene su total destruición, pues él mismo se va mostrando á su enemigo; veenle los Indios, y siguiéndole, en canoas pequeñas, le aguardan á que queriendo respirar saque la cabeça, y clauándole con sus arpones, que hazen de conchas, le quitan la vida: diurdenle en partes medianas, que asadas sobre parrillas de palo, duran sin interrupcion más de un mes.

No hazen dél cezinas para todo el año (que son de mucho precio), por no tener sal en abundancia, que la que vsan para templar sus co* midas, es muy poca, y hecha de cenizas de cierto género de palmas, que más es salitre que sal. 


\section{NVMERO XXVI}

Tortugas del Rio y cómo las guardan

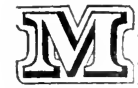

AS ya que no les es dado conseruar les falta industria para tener carne fresca todo el invierno, que aunque no es tan gustosa como aquella, es más sana, y no de menos prouecho.

Hazen para esto unos corrales grandes, cercados de palos, cabados por dentro, de suerte que como lagunas de poco fondo, conseruen siempre en sí el agua llovediza.

Hecho esto, al tiempo que las tortugas salen á desgüeuar á las playas, ellos tambien dexan sus casas, y emboscándose en los puestos conocidos, que ellas más frequentan, esperan á que saliendo á tierra comienze cada vna á ocuparse en componer la cueua donde pretende dexar los guebos; salen en esta sazon los In- 
dios, gánanlas la parte de la playa, por donde han de hacer su retirada al agua, y dando de improuiso sobre ellas en breue tiempo se ven señores de mucha cantidad, con no más trabajo que irlas boluiendo lo de abaxo arriba, con que sin poderse menear, las tienen todo el tiempo que quieren, hasta que ensartadas todas por vnos agujeros que las hazen en el casco, en varios cordeles, y echadas al agua, bogando ellos en sus canoas, las lleuan á remolco sin ningun trabajo hasta meterlas en los corrales que tienen dispuestos, donde sueltas todas, las dan por prision aquella estrecha carcel, y sustentándolas con ramas, y hojas de árboles, las tienen viuas todo el tiempo que las han menester.

Son estas tortugás tan grandes y mayores que rodelas de buen tamaño; es su carne como de baca tierna; tienen las hembras dentro del buche quando las matan, de ordinario, más de doscientos guebos cada vna, algo mayores, y casi tan buenos como los de gallina, aunque más duros de digestion. Estàn á sus tiempos tan gordas, que de dos solas se saca vna botija de manteca, que templada con sal, es tan buena, y más gustosa y dura mucho más que la cocida de bacas; sirue para freir pescado, y para cualesquiera géneros de guisados que por 
acá pueden aprouechar la mejor y más delicada manteca de todas.

Cogen estas tortugas en tanta abundancia, que no ay corral destos que no tenga de cien tortugas para arriba, con que jamás saben estos bárbaros qué cosa sean hambres, pues vna sola basta á satisfacer vna familia por mucha gente que tenga.

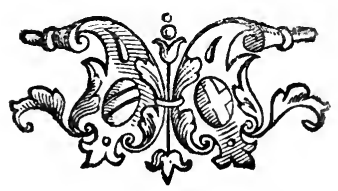




\section{NVMERO XXVII}

Modos de pescar que usan

ON más facilidad gozan los moradores deste Rio de todos los géneros de pescados que en sí encierra, pues nunca rezelando que les ha de faltar para el siguiente dia, se previenen en el antecedente, sino que con lo que oy cogen, sustentados disponen para comer mañana otra cosecha.

El modo de pescar es diuerso, conforme á la variedad del tiempo, y las crecientes ó menguantes de las aguas; y así quando éstas baxan tanto que ya los lagos se secan, sin permitirles comunicacion con el Rio, vsan de vn género de torbisco, que en aquellas costas llaman Timbó, del grosor de vn braço, poco más ó menos, y tan fuerte, que machacados dos ó tres palos distos, y batiendo con ellos el agua, 
que en tanto sustenta en aquellos lagos el pescado, apenas llega este á gustar de su vigor, quando sobre aguado todo se dexa coger con las manos.

Pero el ordinario modo con que en todos tiempos, y ocasiones, son dueños de quantos pescados sustenta este abastecido Rio, es con las flechas que con vna mano disparan de vna paleta que en ella tienen, y clauadas en el pege les haze el oficio de boya, para conocer á dónde despues de herida se retirá la presa, á que con presteza se arrojan, y asiéndola la recogen en las canoas; y este modo de pescado no se estrecha á vno, ó á otro género particular de pescado, sino tan en general, se extiende á todos, que ni los vnos por grandes ni los otros por pequeños, son priuilegiados, mas antes, todos pasan por vn rasero.

Con ser estos pescados de tan diuersos géneros (como ya dixe) son de muy buenos gustos, y muchos dellos de particularísimas propiedades, como lo es la de vn pege, que los Indios le llaman Peraque, que es al modo de vna muy grande anguilla, ó por mejor dezir como un pequeño congrio, el qual tiene tal propiedad, que mientras esté viuo, quantos le tocan tiemblan luego todo e! cuerpo mientras 
el contacto dura, como si tivieran un recio frio de quartanas, cesando todo en el instante que dél se apartan.

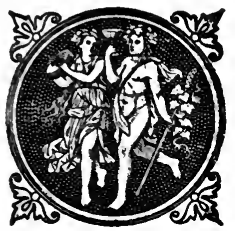




\section{NVMERO XXVIII}

Cafas del monte, $y$ aues de que se sustentan

5 (2) UDIERA ser que hastiados estos natu-rales, siempre con solo pescado, aunque tan bueno, apetecieran, siquiera, de quando en quando, alguna carne, y así les previno la naturaleza sus antojos, poblándoles la Tierra-Firme, con muchos géneros de caças, como son: Dantas, que son del tamaño de vna mula de vn año, y muy parecidas á ella en el color, y disposicion, y el gusto de la carne no se di. ferencia del de la baca, aunque toca algo en dulce.

Ay tambien puercos montarazes, no jaualíes, vno y otro género muy diuerso, que tiene el ombligo en el lomo, de que "están pobladas casi todas las Indias; es muy buena carne $\mathbf{y}$ muy sana, como tambien lo es la de otra espe- 
cie de estos mesmos animales, que se hallan en muchas partes, muy semejantes á los caseros nuestros. Ay Venados, Pacas, Cotias, Iguanas, Yagotis, y otros animales, propios de las Indias, de buenas carnes y de buen gusto, que poco se echan de menos las más regaladas de Europa. Ay perdizes en los campos y crian en sus casas algunas gallinas de las nuestras, cuya semilla baxó del Perú, y de vnos á otros se ha ido extendiendo por todo el Rio; el qual en muchos lagos que haze, les sustenta infinidad de patos y otras aues de agua, para quando ellos quieran aprouecharse dellas. Y lo que más admira es el poco trabajo que cuestan todas estas cosas, como se puede colegir de lo que cada dia experimentáuamos en nuestro Real, de donde, despues de llegar á la dormida, y despues de ocupados los Indios amigos que nos acompañaban, en hazer varracas suficientes pará todo el alojamiento, en que se consumia mucho tiempo, se repartian vnos por tierra, con perros, en busca de caça, y otros por agua, con solo sus arcos y flechas; y en pocas horas velamos venir á éstos cargados de pescado, y á aquellos con caça suficiente para que todos quedásemos satisfechos. Lo qual no era vn dia ó otro, sino todos cuantos duró el viage, que fué tan cumplido como ya dixe. 
60

Marauilla digna de admiracion y que solo se puede atribuir á la Paternal Prouidencia de aquel Señor, que con solos cinco panes y pocos pezes sustentó cinco mil hombres, quedán. dole el braço sano, y las manos llenas, para mayores liberalidades.

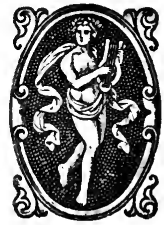




\section{NVMERO XXIX}

Clima y temple del Rio

L clima deste Rio, y todas las Prouin-
cias ál circunvezinas, es templado: de suerte que ni ay calor que enfade, ni frio que fatigue, ni variedad que sea molesta; porque aunque se reconoce algun género de invierno, no es tanto, causado de la variedad de los Planetas, y curso del Sol, que siempre nace y se pone á vna misma hora, como de las inundaciones de las aguas, que con sus humedades impiden por algunos meses las sementeras, $y$ frutos de lá tierra, por los quales nos regimos de ordinario en aquellas partes del Perú, de tan diferentes temples, para conocer y distinguir el verano del invierno; de suerte que todo el tiempo que la tierra nos produce frutos, llamamos verano; y por el contrario, invierno, 
al en que por alguna causa se impiden sus cosechas. Estas son dos al año en este Rio, no solo en los maizes, vno de sus principales sustentos, sino tambien en otras semillas propias de la tierra. Verdad es que las más cercanas á las Cordilleras de Quito, gozan de más calor que lo restante del Rio, por las muchas brisas que de ordinario refrescan lo más propinquo á las costas de la mar, si bien este calor quando mayor, es tanto como lo ordinario de Guayaquil, Panamá ó Cartagena, templándose en gran parte con los continuos aguaceros de casi cada dia, haziéndoles á todas estas tierras gran ventaja en conseruar por mucho tiempo sus mantenimientos incorruptos, como lo experimentamos en las Hostias, con que cada dia dezíamos Misa, que despues de cinco meses y medio que salieron de Quito, estauan tan fres. cas como si fueran de pocos dias hechas y por acabarse á este tiempo, no experimentamos todo lo que en adelante pudieran durar, cosa que espanta á los que tenemos corridos diferentes temples de las Iudias, y sabemos por experiencia la facilidad con que en tierras cálidas se corrompen, aun cosas de más sustancia. No son los Soles deste Rio, con avezindarse tanto á la Equinocial, noziuos, ni se conocen serenos que hagan daño, de que puedo 
ser buen testigo, pues raras veces en todo el tiempo que por él navegué, dexé de pasar las noches de claro en claro, á su inclemencia, sin que jamás me causase un dolor de cabeça, que en otras partes, solo vn pequeño rayo de la Luna los suele causar muy desmedidos, si bien es verdad que en sus primeras entradas, casi todos los que veníamos de tierras frias, tuvimos quatro calenturas, que con otras tantas sangrías nos dexaron libres. Ni tampoco ay en este Rio, ayres corruptos, que con repentinas calidades dexan lisiados á aquellos á quienes más hieren, como á costa de su salud, y á veces de la vida, los sienten muchos, casi en todo lo descubierto del Perú. $\mathrm{Y}$ à no tener la plaga de mosquitos, de que abunda en muchos parajes, se pudiera llamar á boca llena vn dilatado Paraiso.

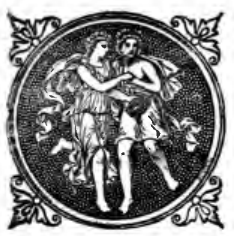




\section{NVMERO XXXI}

Maderas, y aderezos para nauios

OS árboles en este Rio, son sin númetan gruesos, que pone espanto; cedro medí con ris manos de treinta palmos de circuito; son todos por la mayor parte de tan buenas maderas, que no se pueden desear mejores, porquc son cedros, ceibos, palo hierro, palo colorado, y otros muchos, reconocidos ya en aquellas partes y experimentados por los mejores del mundo para fabricar embarcaciones, las quales en este Rio, mejor y con menos costo que en parte ninguna, se podrán, àcabadas y perfectas, echar al agua, sin que se necesite de nuestra Europa sino solo hierro para la clauaçon. Porque aquí, como digo, están las maderas á pedir de boca; aqui la xarcia tan fuer- 
te como la de cáñamo, de ciertas cortezas de árboles, de que se hazen amarras, que solas ellas sajetan las naos en tormentas desechas, aquí la pez y brea tan perfecta romo la Aráviga; aquí el azeyte, asi de árboles como de pescados, para darla punto y templar su dureza. Aqui se saca estopa excelente, que llaman em. bira, que para calefetear las naos, y juntamente para cuerda de arcabuz no se conoce otra mejor. Aquí el algodon para el velambre, es la semilla que mejor produzen los campos, y aquí, finalmente, está la multitud de gente que des- . pues diremos, con que no falta nada para fa. bricar quantos galeones se quisieren poner en astillero.

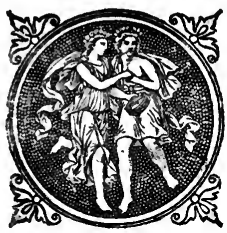




\section{NVMERO XXX}

Disposicion de la tierra y drogas medicinales

(1) ESTA apacibilidad de temples, naze sin que coronadas de varios, y hermosos árboles, parece que á porfía están de continuo dibujando nuevos paises, en que la naturaleza se esmere, y el arte aprenda.

$\mathrm{Y}$ aunque en lo comun es tierra baxa, tiene tambien altos bien proporcionados, campiñas desembaraçadas de arboledas y cubiertas de flores; valles que siempre conseruan la humedad, y en lo más retirado, cerros tales, que pueden con razón pasar con nombre de Corlleras.

En estos incultos bosques, tienen los naturales librada para sus dolencias, la mejor boti: ca de simples, que ay en lo descubierto; por 
que aquí se coge la más gruesa cañasístola que en parte alguna, la çarçaparrilla más perfecta, las gomas y resinas saludakles, mas en abundancia: la miel de auejas siluestres, más á cada paso; y tanto, que apenas se llega á paraje donde no la aya, gastándola, no solo en medizinas, para que es muy saludable, sino tambien sustentándose con ella, por ser de lindo gusto, y aprouechando la cera, que aunque es negra es buena y arde tan bien como cualquitra otra. Aqui el azeyte de Andiroua, que es vn arbol, que no tiene precio para curar heridas. Aquí al de Copaiba, que tambien lo es, no iguala el mejor bálsamo, Aquí se hallan mil géneros de yerbas y árboles de particularísimos efectos; y ay aún por descubrir otras muchas, que pudiera salir segundo Dioscorides y tercero Plinio, y todos tuvieran bien que hazer en aueriguar sus propiedades.

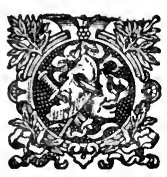




\section{NVMERO XXXII}

Quatro géneros de cosas prouechosas que ay en este Rio.

Y en este gran Rio de las Amazonas 5 quatro géneros que cultiuados, serán sin duda suficientes para enriquecer, no á vno, sino á muchos Reynos, de los quales es el primero maderas, que fuera de auer muchos de tanta curiosidad, y estima como el mejor euano, ay tantas de las comunes para embarcaciones, que juntamente se podrán sacar para otras partes, seguros siempre de que por muchas que se saquen, jamás se podrán agotar. El segundo género es el cacao, de que están sus orillas tan llenas, que algunas vezes las maderas que para el alojamiento de todo el exército, se cortauan; apenas eran otras que las de los árboles que produzen este tan estimado fruto de la Nueua-España, y en donde quiera 
que saben qué cosa es chocolate; el qual beneficiado, es de tanto prouecho, que á cada pie de árbol, corresponde de renta todos los años, horros de todos gastos, ocho reales de plata; $y$ veese bien con quan poco trabajo se cultiuan estos árboles en este Rio, pues sin ningun beneficio de el arte, sola la naturaleza les llena de abundantes frutos. El tercer género, es el Tabaco, de que se halla gran cantidad y muy crecido entre los moradores de sus Riberas; $y$ si se cultiuase con el cuydado que pide esta semilla, seria de los mejores del mundo, porque á juizio de los que lo ertienden, la tierra y temples es todo lo que se puede desear para grandiosa cosecha. Las mayores, que á mi ver, se debiaran entablar en este Rio, son las de Azucar, que es el quarto género, que como más noble, más prouechoso, más seguro, y de mayores acrecentamientos para la Corona Real, y mas en tiempos que tanto ha caido el trato del Brasil, se debiera tomar mas á pechos, y procurar luego á los principios entablar muchos ingenios, que en breue tiempo restaurarasen las pérdidas de aquella costa. Para lo qual no fuera menester, ni mucho tiempo, ni mucho trabajo, ni lo que oy se rezela, mucha costa; pues la tierra para caña dulze, es la más famosa que ay en todo el Brasil, como lo po- 
demos atestiguar los que auemos corrido aquellas partes: porque es toda ella vn mazapé continuado, que es por lo que los labradores destas plantas se desvelan, y con las inundaciones del Rio, que nunca duran sino pocos dias, quedan tan fertilizadas, que antes se puede temer el demasiado vicio.

Y no será nueuo en aquella tierra lleuar caña dulze. pues por todo este dilatado rio, desde sus principios, siempre la fuymos encontrando, que parece daua desde entonces muestra de lo mucho que despues multiplicará quando se quieran hazer ingenios para labrarla. Estos serían de muy poco costo, por tener, como dixe, las maderas á la mano, y el agua en abundancia, y solo se necesitarían cobres, que con mucha facilidad contribuyera nuestra España, codiciosa de el buen retorno que por ellos auia de recibir.

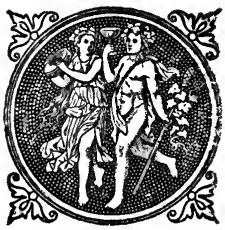




\section{NVMERO XXXIII}

De otros generos de estima que aqui se hallan.

$5 \sqrt{3} \mathrm{O}$ solo estos géneros podian prome. terse en este nueuo mundo descubierto con que enriquecer á todo el Orbe, sino tam. bien otros muchos, que aunque de menor quantía, no dexarian de ayudar con su cornadillo, al aumento de la Corona Real, como son el algodon que se coge en abundancia, el vrucú, que es con lo que tienen perfecto colorado, que los Estrangeros estiman grandemente, la Cañístola, la çarça parrilla, los aceytes que compiten con los mejores bálsamos en el efeto de curar heridas, las gomas y resinas oloro: sas, la pita de que se saca el mas estimado hilo, de que ay grande abundancia, y otros muchos que cada dia ha de ir sacando á luz la nezesidad y la codicia.

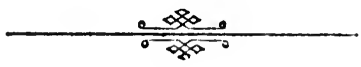




\title{
NVMERO XXXIIII
}

\author{
Riquezas deste Rio
}

O trato de las muchas minas de oro y descubierto, y que se descubrirán forçosamente en adelante, que si mi juizio no me engaña han de ser más y más ricas que todas las del Perú, aunque entren en ellas las de el afamado Cerro de Potosí. Y no digo esto al ayre, y sin fundamento, lleuado solo, como pensará alguno, de la aficion que muestro á engrandecer este Rio, sino estriuando en la razon y en la experiencia; ésta la tengo de el oro que en al. gunos Indios deste Rio encontramos, y de las noticias que dieron de sus minas; aquella me obliga á formar este argumento.

El Rio de las Amazonas, recibe en sí las vertientes todas de las tierras más ricas de la 
América, pues por la vanda del Sür desaguan en el caudaloso Rio, que descienden de cerca del Potosí vnos, otros de Guanuco, Cordillera que se auezinda á la Ciudad de Lima; del Cuzco otros, y otros de Cuenta y Gibaros, que es la tierra más rica de oro, que ay en lo descubierto.

De suerte que por esta parte quantos Rios, quantos manantiales, quantos arroyos, quantas fuentezillas vierten en el Oceano en el espacio de seiscientas leguas zue ay desde Potosí á Quito, todos rinden vasallage y pagan parias á este Rio, como tambien lo hazen todos los que baxan del nueuo Reyno de Granada, no inferior en oro á todos los demás.

Si este Rio, pues, es la calle Mayor, y el principal camino por donde se sube á las mayores riquezas del Perú, bien puedo afirmar que es el principal dueño de todas.

Fuera de que, si el lago dorado tiene el oro quela opinion le atribuye; Si las Amazonas habitan, como atestiguan muchos, entre las mayores riquezas de el Orbe; Si los tocantines en piedras de precio y abundancia de oro, son tan afamados de el Francés; Si los Omaguas con sus aueres alborotaron al Perú, y despa chó luego vn Virey con grueso exército á Pedro de Orsua en busca dellos. En este gran 
Rio está todo encerrado: aquí el lago dorado, aquí las Amazonas, aquí los tocantines, y aquí los ricos Omaguas, como adelante se dirá. Y aquí fiñalmente está depositado el inmenso Tesoro que la Magestad de Dios tiene guarda. do para enriquezer con él la de nuestro gran Rey y señor Philipo Quarto.

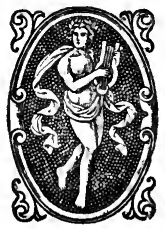




\section{NVMERO XXXV}

Son quatro mil leguas de circuito lo desoubierto

IENE de circuito ests dilatado Impe-
rio, segun buena Cosmographía, al pie de quatro mil leguas; y no pienso que me alargo mucho, porque si solo de longitud, medidas con cuydado, tiene mil y trescientas y cinquenta y seis, y conforme á Orellana, que fue el primero que le nauegó, mil y ochocien. tas; y por cada rio que en él entra de vna $y$ otra vanda, segun buenas informaciones de los naturales, que pueblan sus bocas en más de doscientas leguas por cada vanda, y por muchas partes; ni aun en más de quatrocientas, nunca se sale á la poblacion de Españoles, encontrando siempre Naciones diferentes, fuerça es que le concedamos de anchura, por lo menos, quatrocientas leguas en lo más estre- 
cho, que con las mil y trescientas y cinquenta y seis, ó segun Orellana mil y ochocientas de longitud, le darán de circuito, segun buena Aritmética, muy poco menos de las quatro mil que ya dixe.

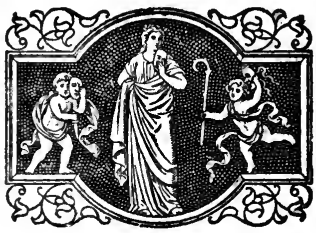




\section{NVMERO XXXVI}

Multitud de gente, $y$ de diferentes Naciones

OSO este nueuo mundo, llamémosle tintas prouincias y Naciones, de las que puedo dar fé, nombrándolas con sus nombres, y señalándolas sus sitios, vnas de vista, y otras por informaciones de los Indios que en ellas auian estado, pasan de ciento y cinquenta, todas de lenguas diferentes, tan dilatadas y pobladas de moradores como las que vimos por todo este camino, de que despues diremos.

Están tan continuadas estas Naciones, que de los vltimos pueblos de las vnas, en muchas de ellas, se oyen labrar los palos en las otras, sin que vezindad tanta les obligue á hazer pazes, conseruando perpetuamente continuas guerras, en que cada dia se matan y cautiuan 
innumernbles almas. Desagüe ordinario de tanta multitad, sin el qual ya no cupieran en aquella tierra. Pero aunque entre sí se muestran belicosos y de brios, ningunos tienen para con el Español, como se notó en todo el viage, en que jamás bárbaro se atreuió á vsar contra los nuestros de otra defensa de la que de ordinario están los cobardes preuenidos, que es la huida que tienen muy á la mano, por nauegar en vnas embarcaciones tan ligeras, que en abordando à tierra las cargan en los hombros, y arrojándose con ellas á vn lago, de los muchos que el Rio tiene, dexan burlado á cualquier enemigo que con su embarcacion no pueda hazer otro tanto.

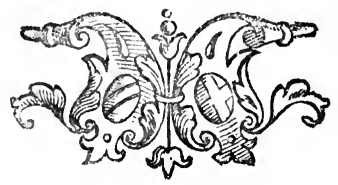




\section{NVMERO XXXVII}

Armas de que vsan los Indios.

VS armas son, en vnos, azagayas media nas, y dardos labrados de maderas fuertes, bien aguzadas, $y$ todas las puntas, que tiradas con destreza, pasan con facilidad al enemigo.

En otros, son estólicas, arma en que los guerreros del Inca, gran Rey del Perú, eran muy diestros; son estas estólicas vnos palos tableados, de vna vara de largo, y tres dedos de ancho, en cuyo remate, á la parte de arriba, fijan un diente de güeso, en que haze presa vna flecha de nueue palmos, cou la punta tambien de gûeso, ó de palo muy fuerte, que labrado en forma de harpon, queđa como garrocha, 
pendiente de aquel á quien hiere; esta cogen con la mano derecha en que tienen la estólica por la parte inferior, y fijándola en el dientesuperior, la disparan con tan gran fuerça $y$ acierto, que á cinquenta pasos no yerran tiro.

Con estas armas pelean, con estas flechan la caça, y con estas son señores de qualquier pescado, por más que se les quiera ocultar entre las ondas: y lo que más admira, con estas clauan las tortugas, quando huyendo de ser reconocidas, solo de quando en quando, y por vn muy breue espacio muestran la cabeça encima de las aguas, atrauesándolas el cuello, que es solo en lo que por estar libre de las conchas se puede hazer el tiro.

Vsan tämbien para su defensa de rodelas, que hazen de cañas brabas, hendidas por medio, y texidas apretadamente vnas con otras, que aunque son más ligeras, no son tan fuertes como las otras que ya dixe, de cuero de Pegebuey.

Algunas destas naciones vsan de arcos y flecha, arma que entre todas las dcmás 'es siempre respetada, por la fuerça y presteza con que hiere.

Abundan de yerbas venenosas, de que hazen en algunas naciones vna ponçoña tan eficaz, 
que enherboladas con ella las flechas, en lle gando á sacar sangre, quitan juntamente la vida.

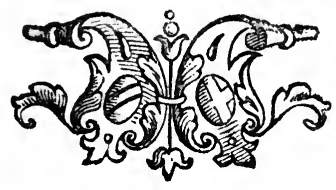


NVMERO XXXVIII

Su comercto es por el agua en canoas.

gran Rio, están poblados en grandes
gran los que viuen á las orillas deste poblaciones, y como Venecianos ó Mexicanos, todo su trato es por agua, en embarcaciones pequeñas, que se llaman canoas; éstas de ordinario son de cedro, de que la Prouidencia de Dios les proueyó abundantemente, sin que les cueste trabajo de cortarlos, ni sacarlos del monte, inuiándoselos con las auenidas del Rio, que para suplir esta necesidad los arranca de las más distantes cordilleras del Perú, y se los pone á las puertas de sus casas, donde cada vno escoge lo que más á quenta le pareze.

$\mathrm{Y}$ es de admirar, ver que entre tanta infinidad de Indios, que cada vno necesita, por lo menos para su familia, de vno ó dos palos, de 
que labra vna ó dos canoas, como de hecho las tienen, à ninguno le questa más trabajo, que saliendo á la orilla, echarle vn lazo quando va pasando, y amarrarle á los mismos vmbrales de sus puertas, donde queda preso, hasta que auiendo ya baxado las aguas, y aplicando cada vno su industria, y trabajo, labra la embarcacion de que tiene necesidad.

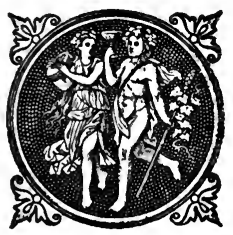




\section{NVMERO XXXIX}

\section{Las herramientas que vsan.}

Grar, no solo sus canoas, sino sus casas y lo demás que han menester, son hachas, y azuelas, no fraguadas por buenos oficiales en las herrerías de Vizcaya, sino forjadas en las fraguas de sus cntendimientos, teniendo por maestra, como en otras cosas, á la necesidad. Esta les enseñó á cortar el casco más fuerte de la tortuga, que es la parte del pecho; vna plancha de vn palmo de largo, y algo menos de ancho, que curada al humo, y sacándola el filo en vna piedra, la fijan en su hastil, y con ella, como con vna buena hacha, aunque no con tanta presteza, cortan lo que se les antoja.

Deste mismo metal hazen las azuelas, siruiéndoles de cabo para ellas, vna quijada de 
Pegebuey, que la naturaleza iormó con su buelta, apropósito para el efecto.

Con estas herramientas labran tan perfectamente, no solo sus canoas, sino tambien sus mesas, tablas, asientos, y otras cosas, como si tuvieran los mejores instrumentos de nuestra España.

En algunas naciones son estas hachas de piedra, que labrada á poder de braços, la adelgazan de suerte, que con menos rezelos de quebrarse, y mas en breue que con las otras de tortuga, cortan qualquier arbol, por grueso que sea.

Sus escoplos, gubias, y cinceles para obras delicadas, que las hazen con gran primor, son dientes, y colmillos de animales, que encauados en sus palos, no hacen menos bien su ofizio, que los de fino azero.

Casi todos tienen en sus Prouincias Algodon vnos mas, otros menos; pero no todos le aprovechan para vestirse dél, mas antes los más andan desnudos, así hombres como rnugeres, sin que la verguiença natural les obligue, á no querer parezer que están en el estado de la inocencia.

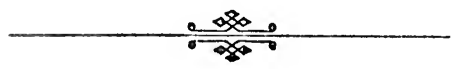




\section{NVMERO XL}

De sus ritos, y Dioses que adoran.

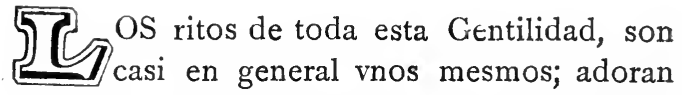
Idolos, que fabrican con sus manos, atribuyendo á vnos el poder sobre las aguas, y así les ponen por diuisa vn pescado en la mano; á otros escogen por dueños de las sementeras, y á otros por ualedores de sus batallas.

Dizen que estos Dioses baxaron del Cielo, para acompañarlos y hazerlos bien: no vsan de alguna ceremonia para adorarlos, mas antes les tienen oluidados en un rincon hasta el tiempo que los han menester, y así quando han de ir á ia guerra, lleuan en la proa de las canoas el Idolo en quien tienen puestas las esperanças de la vitoria; y quando salen á hazer sus pesque- 
rías, echan mano de aquel á quien tienen entregado el dominio de las aguas; pero ni en vnos ni en otros fian tanto, que no reconozcan, pueda auer otro mayor.

Colijo esto de lo que nos sucedió con vno destos Bárbaros, si bien esto no lo mostraua ser en le agudeza de su discurso; el qual hauieudo oydo algunas cosas del poder de nuestro Dios, y visto por sus ojos que subiendo el rio arriba nuestro exército, y pasando por medio de tantas naciones tan belicosas, boluía sin recibir daño de ninguna; lo qual juzgaba, era fuerça y poder del Dios que le regía, llegó con grandes ansias á pedir al Capitan Mayor, y á nosotros, que en pago del hospedaje, y buen agasajo, que nos hazia, no quería otra merced, sino que le dexásemos allí vn Dios de los nuestros, que como tan poderosos en todo, le guardase á el y sus vasallos en paz, y con salud, y justamente les pudiese acudir con el necesario mantenimiento de que necesitauan.

No faltó quien lo quisiese consolar, con dexar en su pueblo enarbolado el Estandarte de la Cruz, cosa que acostumbran hazer los Portugueses entre los Gentiles, no con tan buen zelo como la accion muestra de suyo, siruiéndoles el Santo Palo de la Cruz, leuantado en alto de título, y capa, para colorear sus mayores injus - 
ticias, como son las contínuas esclauitudes de los pobrecitos Indios, que como mansos corderos, !os lleuan en rebaños à sus casas para venderlos los vnos, y servirse con rigor de los otros.

Leuantan pues como digo estos Portugueses la Santa Cruz, y en pago del buen recibimiento de los naturales que en sus pueblos les hazen, la fijan en lo más leuantado del lugar, diziéndoles que la han de conservar siempre intacta; sucede por algun acontecimiento, ó que la Cruz con el tiempo se cayó, y deshizo, ó que maliciosamente ellos por ser Gentiles, y no reconocer estima en ella la derribaron: con que luego les dan los Portugueses la sentencia, y los condenan á todos los cie aquel pueblo por esclavos perpétuos, no solo por su vida, sino para todos sus descendientes.

Por esta causa no corsentí yo que se leuantase la Santa Cruz, y juntamente por no dar al bárbaro que nos pedía vn Dios, ocasion de idolatrar, atribuyendo á aquel madero el poder, y Deidad del que en él nos redimió.

Si bien le consolé con asegurarle que nuestro Dios le haría siempre compañía, que le pidiese lo que auia menester, y fiase dél, que algun dia le traería á su verdadero conocimiento.

Bien persuadido estaua este Indio de que no 

eran sus Dioses los más poderosos de la tierra, pues quería libremente le dexasen otro mayor á quien obedecer.

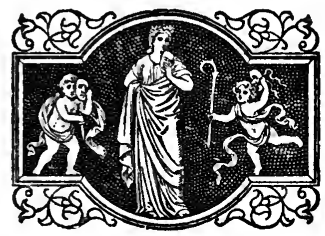




\section{NVMERO XLI}

\section{Vn Indio se hazia Dios.}

(10) EL mismo parecer que el pasado, aunque de mayor malicia, se mostró otro bárbaro: el qual no reconociendo poder, ni Deidad en sus Idolos, él mesmo se hazia Dios de toda aquella tierra.

Deste tuvimos algunas leguas ántes de llegar á su habitacion noticia, y despachándole nueua, de qué se la traimos del verdadero Dios, y más poderoso que no él, le rogamos nos esperase á pié quedo.

Hízolo as1, y apenas llegaron nuestras embarcaciones á tomar puerto en sus Riberas, cuando codicioso de saber del nueuo Dios, salió en persona á preguntar por él.

Pero aunque se le declaró quién era, como no le pudo ver con sus ojos, quedóse en su 
ceguera haziéndose hijo del Sol, adonde con el espiritu afirmaua ir todas las noches para mejor disponer al dia siguiente del vniuersal Gouierno que le incumbía.

Tal era la rnalicia y soberbia deste bárbaro.

Mejor discurso y entendimiento mostró otro que preguntado, por qué causa estando sus compañeros retirados en el monte, rezelosos de la vezindad de los Españoles, él solo con algunos sus parientes salía tan sin temor á meterse en sus manos.

Respondió que consideraua, que gente que hadia subido vna vez por medio de tantos enemigos, y voluía á baxar sin lesion alguna, no era posible menos, sino que como señores de todo este gran Rio, tornasen vna y muchas veces á navegarle y problarle: y que habiendo de ser esto así, no quería andar siempre sobresaltado á sombra de texado, sino salir desde luego á reconocer de grado por amigos á los que los demás haurían de recebir por fuerça.

Discurso bueno, y que permitirá la Magestad de Dios, le ueamos algun dia puesto en execucion.

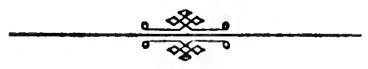




\section{NVMERO XLII}

De los hechizeros que ay

(2) ROSIGUIENDO con el hilo de nuestra
historia, y boluiendo á los ritos destas Naciones. Es para notar la grande estima en que todos tienen á sus hechizeros; no tanto por amor que les muestren, como por el rezelo con que siempre viuen de los daños que les pueden hazer. Tienen para que vsen de sus supersticiones, y hablen con el demonio, que les es muy ordinario, vna casa que solo sirue desto, donde con cierto género de veneracion, como si fueran Reliquias de Santos, van recogiendo todos los güesos de los hechizeros que mueren, los quales tienen colgados en el ayre, en las mesmas amacas en que ellos dormian en vida. Estos son sus Maestros, sus predicadores, sus consejeros y sus guias; á estos acu- 
den en sus dudas para que se las declaren, y destos nezesitan en sus mayores enemistades, para que les den yeruas venenosas con que tomar vengança de sus enemigos. En el enterrar sus difuntos son varios entre sí; porque vnos los tienen dentro de sus mesmas casas, teniendo siempre en todas las ocasiones presente la memoria de la muerte, que si con este fin lo hiziesen, las tendrian sin duda más ajustadas. Otros en hogueras grandes, no solo queman los cadáveres, sino juntamente con ellos quanto poseyeron en vida. $\mathrm{Y}$ así los vnos como los otros, celebran sus exequias por muchos dias con continuos llantos, interrumpidos con grandes borracheras.

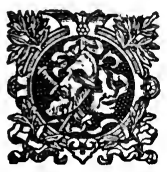




\section{NVMERO XLIII}

Son estos Indios de apacibles natarales

57 S á vna mano toda esta gentilidad, de Duena disposicion, bien agestados, y de color no tar tostado como los del Brasil, tienen buenos entendimientos y raras habilidades para cualquiera cosa de manos.

Son mansos y de apacibles naturales, como se experimentaua con los que vna vez salian al encuentró, que con gran confiança conuersaban, comian y bebian entre los nuestros, sin jamás rezelarse de nada.

Dáuannos sus casas en que viuir, recogiéndose ellos todos juntos en rna, ó dos de las mayores del pueblo; y con recebir infinitos agrauios de nuestros Indios amigos, sin que fuese posible el euitarlos, nunca correspondian con malas obras. 
Todo lo qual junto con la poca aficion $y$ muestras que dan della, de todo lo tocante al culto de sus Dioses: prometen grandes esperanças de que si se les diese noticia del uerdadero Criador de Cielos y tierra, con poc : dificultad abraçarían su Santa Ley.

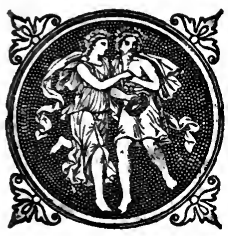




\section{NVMERO XLIIII}

Trátase en especial de las cosas del Rio, y de sus entradas.

ABLADO he hasta aqui en general de
todo lo tocante á este gran Rio de las Amazonas. Razon será ya ir descendiendo en particular á declarar sus entradas á nombrar sus puertos, aueriguar las aguas de que se alimenta, desentrañar sus tierras, s $\in$ ñalar sus alturas, notar las propiedades de sus Naciones, y finalmente no dexar cosa digna de saberse, que como téstigo de vista y persona inbiada de su Magestad, á solo hazer Inquisicion de todo; podré quiza mejor que otros dar con bastantes fundalientos, räzon de lo que tomé á mi cargo.

No trato aquí de la principal entrada deste Rio por el mar Occéano en las costas del gran Pará; que esa, ha ya muchos tiempos, que como 
conocida, y que cae debaxo de la línea Equi. nocial en los vltimos fnes del Brasil: es cursada y sabida de todos los que quieren nauegar á aquellas partes.

$\mathrm{Ni}$ tampoco hago mencion de propósito de la por donde el tirano Lope de Aguirre salió enfrente de la Trinidad, por ser esa transuersal, y que derechamente no se entra por ella á este Rio, sino que teniendo á otras por madre principal, de lance en lance, se viene á dar en braços, que dél deribán su orígen.

Solo es mi intento sacar en limpio, y señalar con el dedo todas las puertas por donde de las partes del Perú, pueden los moradores de aquellas Conquistas tener entrada cierta á este gran Rio: al qual, como ya dixe por la vna $y$ otra vanda de sus riberas, le comunican á otro número de otros muy caudalosos, por cuyas corrientes, es fuerça quien las siguiere que venga á dar en este principal: pero como de cierto no se sabe de qué Ciudades ó Prouincias traigan sus primeros principios, no se puede tratar cosa fija de sus entradas.

Pero podrélo hazer de algunas ocho, en que ningun versado en aquellas tierras, podrá dificultar: tres de estas ázia la vanda del nueuo Reyno de Granada, que está en este Rio á la 
parte del Norte: á la del Sur veremos otras quatro, y vna debaxo de la mesma línea Equinocial.

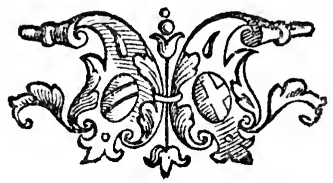




\section{NVMERO XLV}

De tres entradas que ay por el nueuo Reyno.

5 A prinera entrada que por la parte que cae al nueuo Reyno de Granada, está descubierta para este inmenso piélago de aguas dulces, es por la Prouincia de Micóa, que pertenece al Gouernador de Popayan; siguiendo las corrientes del gran Rio Caquéta, que es el dueño, y señor de todas las vertientes, que de parte de Santa Fe de Bogotá, Timaná, y el Caguan, se le allegan; muy afamado entre los naturales, por las grandes Prouincias de Gentiles que sustentan sus orillas.

Este Rio tiene muchos braços por dilatadas Naciones, y boluiéndolos á incorporar en el principal, haze gran multitud de Islas, habita das todas de infinitos bárbaros.

Corre siempre por el rumbo del de las Ama- 
zonas, acompañándole, aunque á lo largo, y echando en él de quando en quando algunos braços, que pudiera bien ser cada vno, cuerpo de qualquiera otro caudaloso Rio; hasta que recogiendo todas sus fuerças, en altura de quatro grados, pecho por tierra se le rinde. Por vno de estos braços que más se auezinda á la Prouincia de los Aguas, de Cabeça chata, es por donde se ha de salir á gozar de las grandezas de nuestro gran Rio de las Amazonas, porque al que se dexare lleuar de los que mas se inclinan á la vanda del Norte, sucederle ha, lo que los años pasados al Capitan Fernan Perez de Quesada, que auiendo entrado por este Rio con trescientos hombres, y dexándose lleuar á la parte de Santa Fé, dió en la Prouincia del Aigodonal, y con ir tan reforçado de gente, le fué fuerça retirarse con más priesa de la que auia lleuado en la entrada.

La segunda puerta, que por la parte del Norte podemos señalar á este Rio es por la Ciudad de Pasto, jurisdicion tambien del Go. uierno de Papayan, de donde atravesando la Cordillera con algunos inconuenientes de mal camino de á pie, que de á cauallo es imposible llegando al Putumayo, y nauegando de Rio abaxo, se vendrán á salir al de las Amazonas, en altura de dos grados y medio, á las tres. 
cientas, y treinta leguas del Puerto de Napo.

Por este mesmo camino, saliendo como dixe de la Ciudad del Pasto, y pasada la Cordillera, acercándose á los Lucumbios, que están no muy lejos del Rio, llamado Aguarico, por otro nombre Rio del oro, se puede salir por él á este principal, casi debaxo de la línea, en el principio de la Prouincia de los Encauellados, que es á las nouenta leguas del dicho puerto de Napo.

- Y esta es la tercera entrada que por la parte del Norte se puede intentar. 


\title{
NVMERO XLVI
}

\author{
Otras entradas
}

S A puerta que para este gran Rio está vierno de los Quixos, más cercana á Quito, en la Ciudad de los Cofanes, de donde por el Rio de la Coca, se coge dasde luego la canal principal del nuestro de las Amazonas, si bien por muchas corrientes que trae, hasta encontrarse con el de Napo, no es tan buena la nauega. cion como será por las demás partes que participan la vanda del Sur.

De las quales, la primera de todas, aunqne no la mejor, es por la Ciudud de Auila en el mismo Gouierno de los Quixos, de donde tres jornadas por tierra se viene á dar en el Rio Payamino, por donde la Armada Portuguesa salió á tomar puerto en la jurisdicion del Quito. 
Desemboca este Rio entre el de Napo, y la Coca, en aquel paraje que llaman las Iuntas de los Rios, á las veinte y cinco leguas del puerto de Napo.

Mejor puerta abrimos á esta mesma Armada, para la vuelta de su viaje, que no la que á la subida, con mucho trabajo y pérdidas, auía descubierto, que es por la Ciudad de Archidona, en la Gouernacion tambien de los Quixos, y jurisdicion de Quito, en donde á solo vn dia de camino, á pie por ser inuierno, que en tiempo de verano, á cauallo se pudiera andar, dimos en el puerto de Napo, Rio caudaloso y en quien los vezinos de todo aquel Gouierno, tienen librado su tesoro, sacando todos los años de sus orillas el oro que necesitan para sus gastos.

Es muy abastecido de pescado, y sus riberas, de caça, de buenas tierras, que agradecidas á poco trabajo de los labradores, rinden colmados frutos.

$\mathbf{Y}$ este es el principal camino por donde con màs comodidades y menos trabajos podrán baxar al Rio de las Amazonas todos los que por la Prouincia de Quito, le quisieren nauegar.

Porque aunque por allá se dize que cerca del Pueblo de Ambato, que está á diez y ocho 
IO4

CHRISTOUAL DE ACUÑA

leguas de la Ciudad de Quito, camino de Rio Bamba, ay entrada á vn Rio que sale á este principal, si no la impide algun salto que hagau las corrientes; es muy apropósito esta baxada por venir á salir al dicho Rio, setenta y siete leguas más abaxo del puerto de Napo, con que se ahorrará todo el camino de los Quixos.

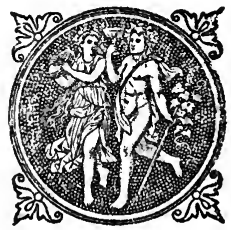




\section{NVMERO XLVII}

Otras entradas á este Rio.

50) OR la parte de la Prouincia de Macas, que cae debaxo de la mesma jurisdicion y Gouierno, de cuyas sierras baxa el Rio Curaray, siguiendo su raudal, se puede tambien salir al de las Amazonas, en altura de dos grados, ciento y cinquenta leguas de Napo, distancia que está bien poblada de diferentes Naciones.

Y esta esta es la séptima entrada de este Rio.

La octaua y última, es por Santiago de las Montañas, y Prouincia de los Maynas, tierras que vaña vno de los mas caudalosos Rios, que al de las Amazonas tributan, en ellas con nombre de Marañon; y en su boca, y muchas leguas antes, de Tumburagua. 
Es este Rio tal, que mas de trescientas leguas, de donde en quatro grados desagua en el principal, se rezela su nauegación, así por su profundidad como por sus precipitadas corrientes: mas con las grandes noticias de los muchos bárbaros que sustenta, mayores dificultades allanan los zelosos de la honra de Dios, y del bien de las almas, en busca de las quales entraron á él á los principios del año de mil y seis cientos y treinta y ocho, dos Religiosos de mi Religion, por los Maynas, de quienes tuve muchas cartas en que no acababan de encarecer su grandeza, y las innumerables Prouincias de que cada dia iban teniendo mayores noticias.

Iúntase este Rio con el principal de las Amazonas, á las doscientas y treinta leguas del puerto de. Napo.

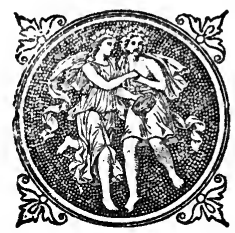




\section{NVMERO XLVIII}

Rio de Napo.

(5) IENE su origen este, tantas veces por mí nombrado Rio de Napo, á las faldas de vn Páramo que llaman de Antezana, que cae diez y ocho leguas de la Ciudad de Quito; y aunque tan vezino á la línea, es de marauillar, que así él, como otros muchos que en varias Cordilleras, coronan aquellas poblaciones, siempre cubiertas de nieue, siruen de templar el calor con que forçosamente, segun afirma San Agustin, la Tórrida zona auia de hazer aquellas tierras inhabitables, quedando con este refrigerio, de las más apacibles y templadas de todo lo descubierto.

Corre este Rio de Napo desde su nacimiento entre grandes peñascos, con que no es nauegable hasta que en el puerto donde los vezi- 
nos de Archidona tienen las rancherías de sus: Indios, más humano y menos bullicioso, consiente sobre sus hombros ordinarias canoas. con que se tragina, y aunque desde este sitio, por quatro ó cinco leguas no oluida sus humos humilde luego hasta incorporárse con el Rio de la Coca, que es á espacio de veinte y cinco leguas con mucho fondo, y gran serenidad, ofrece buen pasage á mejores embarcaciones. Y está la junta de los rios donde Francisco de Orellana con los suyos fabricó el barco con que nauegó por este Rio de las Amazonas.

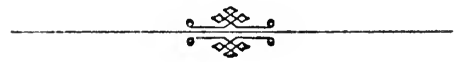




\section{NVMERO XLIX}

Aqui mataron al Capitan Palacios.

(2) VARENTA y siete leguas destas juntas á la vanda de el Sur está Anéte, poblacion que fué del Capitan Iuan de Palacios, muerto á manos de los naturales, como ya diximos.

$\mathrm{Y}$ á las diez y ocho deste sitio desemboca á la vanda del Norte el Rio Aguarico bien co. nocido, así por su temple menos sano, como por el oro que dél se saca, de que tomó tambien nombre de Rio de Oro.

$\mathrm{Y}$ en su boca de la vna y la otra vanda, da principio la gran Prouincia de los Encabellados, que corriendo por la del Norte por más de ciento y ochenta leguas, y gozando siempre de las aguas que el gran Rio da las Amazonas, explaya por caudalosos lagos, des- 
de sus primeras noticias influyó ardientes deseos de sujetarla á toda la jurisdicion de Quito, por la multitud grande de Gentiles de que está poblada, y de hecho en varias ocasiones, se començó á poner por oüra, si bien la vltima en que el Capitan Iuan de Palacios lo intentaua, le salió tan mal como ya vimos.

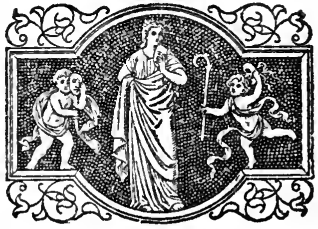




\section{NVMERO L}

Aquí quedó la Armada Portuguesa, Prouincia de los Encabellados.

Ios Encabellados, que cae veinte leguas más abaxo del de Aguarico, donde alló tiene su principio, quedaron á pie quedo por espacio de once meses quarenta soldados de la Portuguesa Armada, con más de trescientos Indios amigos, de los que lleuauan en su compañía.

$\mathrm{Y}$ aunque á los principios hallaron buena acogida en los naturales de la tierra, y por la paga, recebian dellos los mantenimientos necesarios, no duró por mucho tiempo tanta confiança en pechos en que aun todauia heruia la saña con que auían derramado la sangre del Capitan Español, y como ésta por su parte. 
tambien pedia vengança contra sus agresores, rezelosos de que se les auia de castigar su atreuimiento, con pequeña ocasion se alborotaron, y matando tres de nuestros Indios se pusieron en armas para defender sus personas y tierras.

No se descuydaron los Portugueses, que como mal sufridos y peor acostumbrados á semejantes libertades de los Indios, quisieron luego poner por obra el castigo de esta. Toman las armas, y coñ sus ordinarios bríos, dan en ellos de tal suerte, que con pocas muertes cogieron uiuas mas de setenta personas, las quales tuvieron presas hasta que muertas vnas y huydas otras, no quedó ninguna.

Puesto en este estado el Portugués esqua. dron, y que si quería comer lo habia forçosamente de buscar de las manos de el enemigo, ó si no perecer. Determinaror. hazer correrías la tierra adentro, y por fuerça ó de grado redimir su vexacion.

Entrauan vnos y otros quedauan en el Real, y así estos como aquellos, no dexauan de ser molestados por el enemigo, que uiendo la suya acudía á hacer todo el daño que le era posible, como lo hizo en muchas embarcaciones, destroçando vnas y haziendo pedaços las mas flacas. 
Y no fué este el mayor daño que de él se recibió, sino el que sus emboscadas causauan contra nuestros Indios, degollando los que pudieron auer á las manos; si bien pagaron con tres dobladas vidas de los suyos las que quitaron á los nuestros.

Castigo pequeño para los rigurosos que suelen executar los Portugueses en semejantes casos.

Llamaron á estos Indios con nombre de Encabellados, los prirreros Españoles que los descubrieron, por los largos cabellos, que así hombres como mugeres vsan, que á algunas les pasan de las rodillas.

Sus armas son dardos, su habitacion, casas pagizas hechas con curiosidad, y sus mantenimientos los ordinarios de todo el Rio.

Tiene contínuas guerras con las naciones circunuezinas, que son los Seños, Becabas, Tamas, Chufias, y Rumos.

Corren enfrente de esta Prouincia de los Encabellados por la vanda de el Sur, las de los Auixiras, Iurufunes, Zaparas, y Iquitos, que encerrados entre las aguas de este Rio, y el de Curaray fenecen.

Donde tambien entrambos se convierten en vno, que es á las quarenta leguas de los Encabellados en casi dos grados de altura. 


\section{Rio I umguragua.}

Ochenta leguas de Curaray á la misma vanda, desemboca el famoso Rio Tumguragua, que ya dixe arriba, baxaua por los Maynas con nombre de Marañón; házese respetar del de las Amazonas de tal suerte, que con tener este todo su caudal junto, detiene algunas leguas antes su ordinario curso, dando lugar á que aquel explayado por màs de vna legua de boca, le entre á besar la mano, pagándole no solo el ordinario tributo que de todos cobra, sino otro muy abundante de muchos géneros de pescados que hasta la boca deste Rio, no se conocen en el Amazonas.

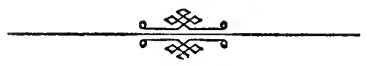




\section{NVMERO LI}

Prouincia de los Aguas.

ESENTA leguas más abaxo de Tunguragua comiença la mejor y más dilatada Provincia de quantas en todo este gran Rio encontramos, que es la de los Aguas, llamados comunmente Omaguas, impropio nombre que les pusieron quitándoles el natiuo, y ajustado à su habitacion, que es á la parte de afuera, que esto quiere dezir Aguas.

Tiene esta prouincia de longitud más de doscientas leguas, continuándose sus poblaciones tan á menudo, que apenas se pierde vna de vista, cuando ya se descubre otra.

$\mathrm{Su}$ anchura es al parecer poca, pues no pasa de la que tiene el Rio, en cuyas Islas, que son muchas, y algunas muy grandes, tienen su habitacion: pero considerando, que todas, ó 
están pobladas, ó cultiuadas, por lo menos: para el sustento destos naturales, se podrá hazer concepto de los muchos Indios que en tan cumplida distancia se alimentan.

Es esta gente la de más razon y mejor gouierno que ay en todo el Rio, ganancia que les grangearon los que dellos estuvieron de paz, no ha muchos años, en el Gouierno de los. Quixos, de donde obligados del el mal tratamiento que se les hazia, se dexaron venir el Rio abaxo, hasta encontrar con la fuerça de los de su Nacion; y introduciendo en ellos algo de lo que hauian aprendido de los Españoles, les pusieron en alguna policía.

Andan todos con decencia vestidos, así hombres como mugeres, las quales del mucho algodon que cultiuan texen no solo la ropa que han.menester, sino otra mucha que les. sirve de trato para las Naciones vezinas, que con razon codician el trabaxo de tan sutiles texedoras; hazen paños muy vistosos, no solo texidos de diuersos colores, sino pintados con estos mismos tan sutilmente, que apenas se distingue lo uno de lo otro.

Son tan sugetos y obedientes á sus principales Caziques, que no han menester más de vna palabra para ver luego executado lo que ordenan. 
Son todos de cabeça chata, que causa fealdad en los varones, si bien las mugeres mejor lo encubren con el mucho cauello; y está en ellos tan entablado el vso de tener las cabeças aplastadas, que desde que nacen las criaturas, se las meten en prensa, cogiéndoles por la frente con vna tabla pequeña, y por la parte del cerebro con otra tan grande, que siruiendo de cuna, recibe todo el cuerpo del recien nacido; el qual puesto de espaldas sobre esta, y apretado fuertemente con la otra, queda con el cerebro y la frente tan llanos como la palma de la mano; y como estas apreturas no dan lugar á que la cabeça crezca más que por los lados, viene á desproporcionarse. De manera que más parece Mitra de Obispo mal formada que cabeça de persona.

Tiene por la vna y la otra vanda del Rio contínuas guerras con las Prouincias extrañas, que por la del Sur entre otros, son los Curinas, tantos en número, que no sólo se defienden por la parte del Rio, de la infinita multitud de los Aguas, sino que juntamente sustentan las armas contra las demás naciones, que por la parte de tierra les dan continuada batería.

Por la vanda del Norte, tienen estos Aguas por contrarios á los Teamas, que segun bue. nas informaciones, noson menos, ni de menos 
brios que los Curinas, pues tambien sustentan guerras á los contrarios que tienen por la tierra adentro.

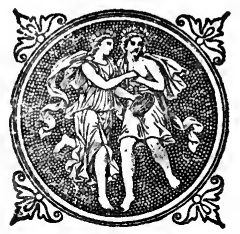




\section{NVMERO LII}

Vso de los esclauos que cautiuan.

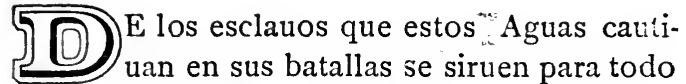
lo que han menester, cobrándoles tanto amor, que comen con ellos en vn plato, y tratarles de que los vendan es cosa que lo sienten mucho, como por experiencia lo vimos en muchas ocasiones.

Llegáuamos à vn pueblo destos Indios, recibíannos, no solo de paz, sino con danças y muestras de grande regocijo, ofrecian quanto tenian para nuestro sustento con gran liberalidad.

Compráuanseles paños, texidos y labrados, que con voluntad dauan, tratáuaesles de venta de las canoas, que son sus cauallos ligeros en que andan, al punto salían á concierto. 
Pero en nombrándoles esclauos, y apretándoles á que los vendiesen, boc opus, bis labor ést, aquí era el descompadrar, aquí el entristecerse, aquí las trazas de encubrirlos, y aquí el procurarse zafar de nuestras manos; muestras ciertas de que más los estiman á solos ellos, y más sienten el venderlos que deshazerse de todo lo demás que poseen.

$Y$ no diga nadie, que el no querer vender los Indios sus esclauos, nace de tenerlos para comer en sus borracheras; que es dicho comun con muy poco fundamento, de los Portugueses, que andan metidos en este trato, y con esto quieren colorear su injusticia.

Porque á lo menos en esta nacion, ya auerigüé con dos Indios de los que hauran subido con los mismos Portugueses, y eran naturales del Pará, los quales huidos desde Quito, vinieron á ser cautiuos destos Aguas, con quienes estuvieron ocho meses, y fueron á algunas guerras en su compaña (tiempo bastante para conocer sus costumbres).

Estos aseguraron que jamás les auian visto comer los esclavos que traian, sino que lo que vsaban con los más principales y valientes, era matarlos en sus fiestas y juntas generales, rezelando mayores daños si les conseruaban la vida; y arrojando los cuerpos en el Rio, guar- 
daban por trofeo las cabeças en sus casas, que eran las que por todo el camino veníamos encontrando.

No quiero con esto negar que hay en este Rio gente Caribe, que en ocasiones, no tiene horror de comer carne humana.

Lo que quiero persuadir, es no ay en todo él carnicerías públicas en que todo el año se pesa carne de Indios como publican los que á título de euitar semejante crueldad la vsan ellos mayor, haziendo con sus rigores y amenaças esclauos á los que no lo son.

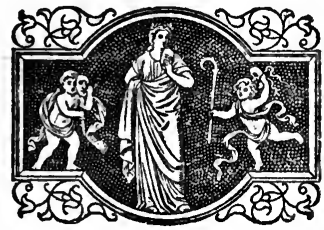




\section{NVMERO LIII}

Sitio frio en que se podrá coger trigo.

1as cien leguas, poco más ó menos, de 5 as primeras poblaciones destos Aguas (que caen tres grados de la Equinocial) y vienen á ser el riñon desta dilatada Prouincia, llegamos á vn pueblo, donde estuvimos tres dias, con tan buen írio, que los nacidos, y criados en las más frias de España, huvimos menester añadir ropa á la ordinaria.

Causóme admiracion mudança tan repentina de temples y preguntando á los naturales, si aquello era cosa extraordinaria en aquella poblacion, me aseguraron que no, porque todos los años espacio de tres Lunas, que así cuentan ellos, y es lo mismo que dezir tres meses, experimentauan todos los años aquellos frios, que conforme lo que ellos afirmaron son 
los de Ínio, Iulio y Agosto. Pero yo aun no bien satisfecho de su dicho, quise con más fundamento hazer Inquisicion de la causa de frio tan penetrante, $y$ hallé que lo era vna gran sierra, ó páramo, que á la vanda del Sur la tier ca adentro está situada, por la qual pasan todos aquelios tres meses los vientos, y helados con la fuerça de la nieue de que está cubierta, causan tales efectos en la tierra circun vecina.

$\mathrm{Y}$ siendo esto asi, no ay duda sino que en este sitio se dará muy buen trigo, y todas las demás semillas y frutas que produce la comarca de Quito, que aunque situada debaxo de la línea, semejantes ayres pasados por nueuos cerros, la habilitan á tales marauillas.

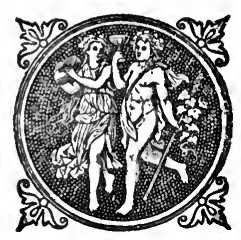




\section{NVMERO LIV}

Rio Putumayo, y naciones que en él y en Yetaú ay.

(D) IEZ y seis leguas destas Potlaciones á la vanda del Norte desemboca el gran Rio Putumayo, bien conocido en el Gouierno de Popayan, por ser tan caudaloso, que antes de desaguar en el de las Amazonas, entran en él treinta fcaudalosos rios: llámanle los naturales en este paraje Vza.

Desciende de las Cordilleras de Pasto ázia el nuevo Reino de Granada, tiene mucho oro, y segun nos afirmaron, está muy poblado de Gentiles; á cuya causa se retiraron con alguna pérdida los Españoles que por él baxaron pocos años há.

Los nombres de las Prouincias que le habitan, son: Yurunas, Guaricús, Yacariguaras, Parianas, Ziyus, Atuais, Cunas, y los que más á 
sus principios de vna y otra vanda, como señores deste Rio, le pueblan, son los Omaguas, a quienes los Aguas de las Islas llaman Oma. guasyeté, que quiere dezir Omaguas verda. deros.

A las cinquenta leguas desta boca, à la par. te contraria, encontramos la de vn hermoso y caudaloso Rio, que trayendo su orígen de ázia el Cuzco, feneze en el de las Amazonas en al. tura de tres grados y medio; llámanle los naturales Yetaú, y tiene entre ellos mucho nombre, así por sus riquezas, como por la multitud de naciones que sustenta, como son las Tipunas, Gunarús, Ozuanas, Morúas, Naunas, Conomomas, Marianas, y los vltimos que más se auezindan á los Españoles que pueblan el Perú, son los Omaguas, que dicen son gente riquísima de oro, que traen en grandes planchas pendientes de las orejas y narices, y si no me engaña mi discurso, segun lo que ler en la historia del tirano Lope de Aguirre, esta era la Prouincia de los Omaguas, en cuyo descubrimiento iva Pedro de Orsua, inuiado del Virey del Perú, por las muchas noticias que de sus aueres auia publicado la fama. Pero el no encontrar con ella, nació de que tomando su entra. da por vn braço de Rio que sale algunas leguas más abaxo, 'quando desembocó en el de las 
Amazonas, ya quedauan estas Naciones tan arriba, que le fué imposible el voluer á ellas rezeloso del impetu de las corrientes, y principalmente por el poco gusto con que ya sus soldados tituveauan.

Es este Rio de Yetaú muy abundante de pesca y caça, y que según las informaciones de sus moradores, se puede nauegar por él con facilidad, por ser de suficiente fondo, y las corrientes moderadas.

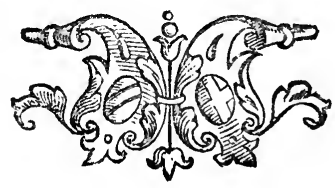




\section{NVMERO LV}

Fin de la Prouincia de los Aguas, y Rio ảel

Cuzco.

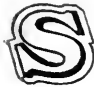

IGUIENDO el curso de nuestro Rio principal, dimos á las catorce leguas en la vltima poblacion de la dilatada Prouincia de los Aguas, que fenece con vn lugar muy populoso, y de muchos soldados, en fin como primera fuerça que por esta parte resiste el ímpetu de sus contrarios. De los quales en espacio de cinquenta y quatro leguas, ningunos pueblan las riberas del Rio, de suerte que dél se de vista á sus rancherias, mas algo retirados á dentro en la Tierra-Firme, por pequeños brazuelos, salen á buscar dél lo que necesitan.

Estos son en la vanda del Norte los Cüris y Guayrabas; y en la del Sur, Cachiguarás y Tucuriys. Pero aunque como digo no pudimos dar vista á estas naciones, dímosla á la boca 
del Rio, que con razon le podemos llamar del Cuzco, pues segun vn regimiento desta nauegacion, que vi de Francisco de Orellana, está Norte Sur con la misma ciudad del Cuzco. Entra en el de las Amazonas en cinco grados de altura, y á las veinte y cuatro leguas del vltimo pueblo de los Aguas: llámanle los naturales Yurúa, que tendiéndose hasta sus orillas, quedacomo aislada entre entrambos Rios. Y este es por donde Pedro de Orsua baxó del Perá, si mi fantasía no me engaña. 


\section{NVMERO LVI}

\section{Prouincia donde se halló oro}

EINTE y ocho leguas más abaxo del
Rio Yurua, á la mesma vanda del Sur, en tierras de muy altas barrancas, da principio la muy poblada nacion de los Curuzirarís, que siguiendo siempre vna ribera corre por espacio de ochenta leguas, tan continuadas sus poblaciones, que apenas se pasanan quatro horas sin encontrar otras de nueuo; y á vezes por espacio de medio dia entero no cesáuamos de mirar sus rancherias.

Destas las más halláuamos sin gente, que con nueuas falsas de que uenramos destruyendo, matando, y cautiuando, casi todos estauan retirados á los montes, fuera de que ellos son de suyo de naturales más esquiuos que otros ningunos deste Rio. 
Si bien no muestran inenos gouierno y policía, segun se echó de ver, así por los muchos mantenimientos de que estauan preuenidos, como tambien por las alajas de sus casas, que para el beneficio de las cosas tocantes á la vida eran de las mejores de todo el Rio.

Tienen en las barracas donde moran muy buen barro para todo género de basijas, $y$ aprouechándose dél, fabrican grandes ollerias, en que labran tinajas, ollas, hornos en que cuezen sus harinas. Cazuelas, jarros, librillos y hasta sartenes bien formadas, teniendo todo esto preuenido para trato comun con las demas Naciones, que obligadas de la necesidad que destos géneros pasan en sus tierras, vienen á hazer grandes cargazones de ellos, recibiendo por paga las cosas de que ellos necesitan.

A la primera aldea desta Nacion viniendo Rio abaxo, llamaron los Portugueses, á la subida, aldea del Oro, por auer hallado en ella y rescatado alguno, que en planchas pequeñas traían los Indios pendientes de las narices, y orejas, que en Quito se provó, y halló ser de veinte $y$ vn quilates mucho de ello.

Como los naturales vieran la codicia de los Soldados, y que tan á pechos se tomaba el hazer diligencia para que se les entregasen más de aquellas planchitas, luego las recogieron 


\section{DESCUBRIMIENTO DEL AMAZONAS}

todas, sin que más pareciese ninguna, lo qual obseruaron tambien á la buelta.

De suerte, que aunque vimos muchos Indios, solo vno trajo dos orejas de oro, bien pequeñas, que yo le rescaté.

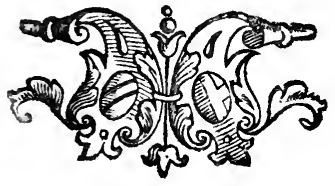




\title{
NVMERO LVII
}

\author{
Minas de Oro.
}

O se pudo á la subida de la Armada
aueriguar con fundamento cosa alguna de cuantas se $\in$ ncontraron en este Rio, porque jamás tuvieron lenguas, con quienes hazer la Inquisicion, y si de algo les pareció á los Portugueses, que podían dar razón, era de lo que por señas auian entendido; las quales eran tan inciertas, que cada uno las aplicaua á lo que tenfa en su pensamiento.

Todo lo qual cesó á la buelta. queriendo nuestro Señor fauorecer á esta jornada, con preuenirla de ordinario de buenos lenguas, por medio de los quales, se aueriguó todo lo que se contiene en esta relacion.

La que á mí me dieron de las minas de donde se sacaua este oro es la que aquí diré.

Enfrente desta aldea algo más arriba à la 
vanda del Norte, entre vn Rio llamado Yurupazr, subiendo por él qual, y atrauesando en cierto parage por tierra tres dias de camino hasta llegar á otro que se llama Yupura, por él se entra en el Yquiari que es el Rio de el Oro, donde de el pie de vna sierra que allí está, le sacan los naturales en grande cantidad; y este oro, todo es en puntas y granos de buen tamaño, de los quales forman á fuerça de batirlo, las planchas que ya diximos cuelgan de las orejas y narices.

Los naturales que contratan con los que sacan este oro, se llaman Managús, y los mismos que habitan el Rio, y se ocupan en sacar. lo, Yumaguaris, que quiere dezir sacadores de metal; porque Yuma, es el metal, y Guaris los que lo sacan, y llaman todo género de metales con este nomhre general de Yuma, y así para qualquiera herramienta de las nuestras, como eran hachas, machetes, y cuchillos, vsauan deste mismo bocablo Yuma.

Dificultosa parece la entrada á estas minas por los inconuenientes que muestra en mudar Rios, y abrir caminos por tierra, y así no me satisfice hasta descubrir otra muy más fácil, de que adelante diremos.

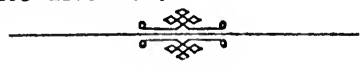




\section{NVMERO LVIII}

$V_{\text {san }}$ orejas $y$ narices agujereadas.

5 TTÁN estos Bárbaros desnudos todos, 21) así hombres como mugeres, sin que les sirua su riqueza más que de vn pequeño atauio con que adornar orejas y narizes, que casi todos tienen agujereadas, y en las orejas lo afec$\tan$ tanto, que á muchos les cabe todo el puño por el agujero que en la parte de abaxo, donde suelen pender los zarcillos, tienen, trayéndole de ordinario ocupado con un mazo de ajustadas ojas, que en él por gala acostumbran.

Por la vanda de enfrente de todas estas poblaciones altas, es tierra llana, á vna mano, y tan cerrada, así de otros Rios, como de los braços que el Caqueta tiende por sus orillas, que aislada en grandes lagos corre por muchas 
leguas, hasta que todos encorporados en el Rio Negro se juntan con el principal.

Están pobladas estas Islas de muchas naciones, pero la que más se extiende por ser más populosa, es la de los Zuanas.

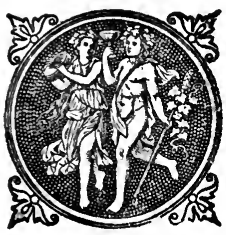




\section{NVMERO LIX}

Entrada á las minas del Oro.

1. ATORCE leguas desta aldea que llamamos del Oro, á la vanda del Norte, sale la boca del Rio Yupura, que es por donde se entra en el del Oro, y esta es la más cierta y derecha entrada para con brevedad llegar á dar vista á la tierra que tan liberal ofrece sus tesoros.

Es la altura de la boca deste Rio de dos grados y medio: como tambien la de vna po. blacion, que quatro leguas más abaxo, en la vanda del Sur, está situada, sobre vna grande barranca, al desembocar de un caudaloso, y claro Rio que los naturales llaman Tapí, y tiene en sus riberas mucha multitud de Gentiles que llaman Paguanas.

Son todas las tierras que, como dixe, por 
espacio de ochenta leguas ocupan esta nacion de los Curuzirarí, muy altas, de lindas campiñas, y yerbas para ganados, arboladas no muy cerradas, abundantes lagos, y que prometen muchas y buenas comodidades á los que las poblaren.

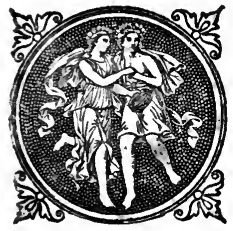




\title{
NVMERO LX
}

\author{
Lago Dorado.
}

57 EINTE leguas del Rio Tapi, desagua en el de las Amazonas el Catuá, que for mando en la boca un grande lago de agua verde, trae él su origen de muchas leguas de tierra á dentro á la vanda del Sur, tan pobladas sus orillas de Bárbaros, como todas las demás. Si bien le haze uentaja en multitud de naciones diuersas, otro Rio, que con el nombre de Araganaruba, seis leguas más abaxo, sale á la parte del Norte, por el qual tambien se comunica el Yupura, de que arriba tratamos.

Llámanse estas naciones Yaguanais, Mucunes, Mapiarús, Aguaynaús, Hutrunas, Mariarúas, Yamarúas, Terarús, Liguiyas, Guanapuris, Piras, Mopiritus, Ignaranis, Aturiaris, Macaguas, Mafipias, Guayacaris, Anduras, Caguaraús, Maraymumas y Guanibis. 
Entre estas naciones, que todas son de diferentes lenguas, segun las noticias que por la parte del nueuo Reyno de Granada ay, está el deseado Lago Dorado, que tan inquietos tiene los ánimos de toda la gente del Perú. No lo afirmo de cierto, pero algun dia querrá Dios que salgamos desta perplexidad. Porque no la aya con el nombre de vn Rio que sale á la vanda del Norte, diez y seis leguas de Araganatuba, y se llama como él, se deue advertir que entrambos á dos son vno mismo, que por dos distintos braços de vn nombre desaguan en el de las Amazonas. Y á las veinte y dos leguas deste braço vltimo da fin la populosa y rica nacion de Curuzirarís, pobladores de vno de los mejores migajones de tierra que en todo este gran Rio encontramos.

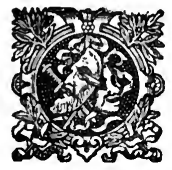




\section{NVMERO LXI}

Prouincia de Yoriman

OS leguas más abaxo, coraiença la más nombrada y belicosa nacion de todo el Rio de las Amazonas, y con quien es ensus primeras entradas, atemorizauan a toda la Armada Portuguesa, que es la de Yoriman. Está á la vanda del Sur ocupando, no solo la tierra firme de sus orillas, sino tambien mucha parte de sus Islas, y aunque de longitud se estreeha en pocas más de sesenta leguas, como se aprouecha de las Islas y Tierra firme está tan sobrada de gente, que en parte ninguna vimos juntos más Bárbaros que en ella. Son comunmente más bien agestados y de mejores talles que los otros; andan desnudos como ellos, y se echa de ver que fian de su välor, pues con gran seguridad entrauan y salian entre los nues- 
tros, viniendo cada dia al Real más de doscientas canoas cargadas de niños y mujeres, con frutas, pescados, harinas y otras cosas, que con abalorios, agujas y cuchillos se les rescatauan.

Está la primera poblacion desta Prouincia situada sobre la boca de un Rio cristalino, que muestra ser muy caudaloso por la grande fuerca con que impele las aguàs del principal. Estará sin duda como todos los demás, susten. tando en sus riberas otras innumerables naciones, de que no supimos los nombres por caminar de paso por su boca.

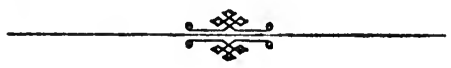




\section{NVMERO LXII}

\section{Vn pueblo de más de vna legua de largo}

57 EINTE y dos leguas de la primera poblacion de Yoriman, tiene su sitio la mayor que en todo el Rio encontramos, ocupando sus casas más de vna legua de largo; y no uiue en cada casa una sola familia, como de ordinario sucede en nuestra España, sino que las menos que debaxo de cada techo se sustentan son quatro ó cinco, y muchas vezes más; de donde se podrà colegir la multitud de todo este pueblo, el qual pacífico en sus casas nos aguardó sin saltar persona dellas, dándonos todos los mantenimientos que huvimos menester, de que ya el exército necesitaua.

Aquí estuvimos cinco dias, y en ellos se hicieron para matalotaje, pasadas de quinientas fanegas de harina de mandioca, con que 
huvo de comer para todo lo restante del camino. Este proseguimos, topando muy á menudo poblaciones desta mesma nacion. Pero donde existe junta la mayor fuerça della, es treinta leguas mas abaxo, en vna grande Isla, cercada de vn braço que arroja el rio principal, en vusca de otro que le viene á pagar tributo, y juntamente por las riueras deste nueuo güésped, donde son tantos estos naturales, que con razon, aunque no sea más que por su multitud, son temidos y respetados de todos los demás.

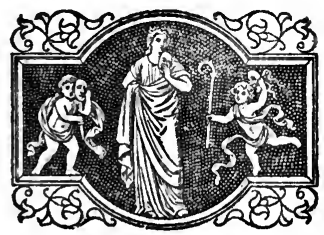




\section{NVMERO LXIII}

Rio de los Gigantes.

5 (0) IEZ leguas adelante del sitio referido, da fin la Prouincia de Yoriman. Y pasadas otras dos, desemboca á la vanda del Sur un famoso Rio, que los Indios llaman Cuchiguará.

Es nauegable, aunque en partes con algunas piedras; tiene mucho pescado, gran suma de tortugas abundancia de maiz y mandioca, y todo lo necesario para facilitar su eutrada.

Está poblado este Rio de varias naciones, que comenzando por su boca, y prosiguiendo por él arriba, son las siguientes:

Los Cachiguaras. que toman el mesmo nomtre del Rio, Cumayaris, Guaquiaris, Cuyariya 
yanas, Curucurus, Quatanfis, Mutuanis, y por fin y remate de todos están los Curiguerés, que segun las informaciones de los que los auían visto, y que se ofrecían á lleuarnos á su tierra, son Gigantes de diez y seis palmos de altura, muy valientes, andan desnudos, traen grandes patenas de oro en las orejas y narizes, y para llegar a sus pueblos son necesarios dos meses contínuos de camino desde la boca del Cuchiguará.

Por el de las Amazonas abaxo, á la vanda del Sur, corren los Caripunás, y Zurinas, gente la mís curiosa que hay en todo él, en labrar de manos, sin más herramienta que las que arriba dixe, hacen bancos forjados en forma de animales, con tanto primor, y tan acomodados para tener el cuerpo con descanso, que ni la comodidad, ni el ingenio, los pudiera fingir mejores.

Labran estólicas, que son sus armas, de palos muy vistosos, tan delicadamente, que con razon las codician las demás naciones.

Y lo que más es, sacan de un tosco leño vn Idolillo $\tan$ al natural, que tuvieran bien que aprender dellos, muchos de nuestros Escultores.

Y no solo les son todas estas obras de entretenimiento y comodidad propia, sino 
tambien de mucho prouecho, hallando á trueque dellas, entre las demás, todo lo que han menester.

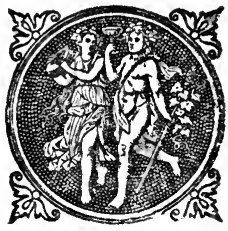




\section{NVMERO LXIIII}

\section{Rio Basururu, y sus naciones.}

R agua este Rio Cuchiguará lo haze tambien, á la vanda idel Norte otro, con nombre entre los naturales, de Basururú, que diuidido la tierra adentro en grandes lagos, la tiene toda partida en muchas Islas, las quales todas pueblan infinitas naciones.

Son tierras altas, y que nunca se anegan, por mayores inundaciones que aya, muy fértiles de mantenimientos, asi de maízes, mandioca y frutas, como tambien cee caças, y pescados, con que los naturales viuen hartos, y se multiplican cada día más.

Llámanse en general todas las naciones que habitan este dilatado sitio, Carabayanas; y en particular las Prouincias en que están divididos, son lás siguientes: 
Caraguanas, Pocoanas, Vrayarís, Mafucarüanas, Quererús, Cotacarianas, Moacaranas, Yaribarus, Yarucaguacus, Cumaruruayanas y Curuanaris.

Vsan estos Indios de arco y flecha; ay entre algunos dellos herramientas de yerro, como son hachas, machetes, podones y cuchillos, $y$ preguntando con cuydado por los lenguas, de donde les vienen, responden que las compran de los naturales que por aquella parte están más cercanos al mar, á los quales se las dan vnos hombres blancos como nosotros, que vsan nuestras mesmas armas, espadas y arca. buzes, que en la costa del mar, tienen su habitacion y que solo se distinguen de nosotros en el cabello, que á vna mano le tienen todos amarillo, señas bastantes para poderse colegir con claridad, son los Olandeses, que hácia la boca del Rio Dulce, ó el Felipe, ha dias tiener tomada posesion.

$\mathrm{Y}$ el año de treinta y ocho, dieron con fuerça de gente en la Guayana, jurisdición del nueuo Reino de Granada, y no solo se apoderaron della, sino que fué tan de improuiso, que no pudiendo los nuestros sacar el Santísimo Sacramento, quedó cautiuo en poder de sus enemigos, que como sabian quan estimada es esta prenda entre los Católicos, espe- 
rauan grande rescate por ella, el que se les aparejaua quando salimos de aquellas partes, eran buenas compañias de Soldados, que con ánimo Christiano, iuan á dar las vidas por rescatar á su Señor; con cuyo fauor, se lograrian sin duda tan buenos deseos.

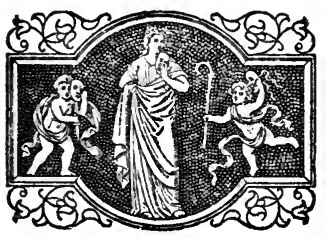




\title{
NVMERO LXV
}

\author{
Rio Negro.
}

VN no treinta leguas cabales más abaxo $\triangle$ de Bafururú en la misma vanda del Norte, en altura de quatro grados, sale al encuentro del de las Amazon ss el mayor, y más hermoso Rio, que en más de mil y trescientas leguas le rinde vasallage.

Si bien como tan poderoso en su entrada, que es de legua y media de ancho, parece quc se corre de reconocer otro mayor, y aunque el de las Amazonas con todo su caudal le echa los braços, no se le queriendo sugetar hombro con hombro, sin respeto alguno, señoreando de la mitad de todo el Rio, le acompaña por más de doze leguas, distinguiéndose claramente las unas aguas de las otras, hasta que no sufriendo el de las Amazonas tantas mayorias, 
reuoluiéndole en sus turbias hondas, le hace entrar por camino, y reconocer por dueño al que él quería auasallar.

Llamaron los Portugueses, y con mucha razon á este gran Rio el Negro, porque en su boca, y muchas leguas más adentro, el mucho fondo que tiene y la claridad del agua que de inmensos lagos en él vierte, le hazen parecer tan negras sus hondas, como si de propósito estubieran teñidas, si bien fuera de su natural son cristalinas.

Haze su curso de Oeste á Eeste en sus principios, aunque las bueltas son tantas, que á distancias muy cortas muda rumbos diferentes; el que trae por muchas leguas antes de entrar en el de las Amazonas es el de Poniente á Orien. te. Llámanle los naturales que le habitan Curiguacurú.

Si bien los Tupinambas, de quienes des pues diremos, le pusieron por nombre Vruna, que en su lengua quiere dezir agua Negra.

Como tambien llamaron al principal de las Arrazonas en este parage, Paranaguazú, que significa Rio grande, á distincion de otro menor, pero muy caudaloso, que llaman Paranamirí, esto es, Rio pequeño, que desagua á la vanda del Sur, vna legua antes de el Rio $\mathrm{Ne}$ gro, que afirman estar muy poblado de dife- 
rentes naciones; la vltima de las quales está vestida, y vsan sombreros; señal cierta de que se auezindan á los Españoles de el Perú.

Los que lo están á las aguas de el Rio $\mathrm{Ne}$. gro, son grandes Prouincias, es á saber los Canizuarís, Aguayras, Yacuncaraes, Cahuayapitis, Manacarús, Yanmas, Guanamas, Carapanaris, Guarianacaguas, Azerabarís, Curupatabas, y los que primero pueblan vn braço que este Rio arroja, por donde segun informaciones, se viene á salir al Rio Grande, en cuya boca en el mar del Norte están los Olandeses, con los Guanranaquazanas.

Vsan todas estas Naciones de arco y flecha, muchas dellas enherboladas con ponçoña.

Son todas las deste Rio tierras altas, de lindo migajon, y que cultiuadas, prometen qualesquier frutos, aun de los de nuestra Eüropa en algunas partes; tienen muchas y buenas campiñas cubiertas de sazonados pastos para poder en ellas pastar innumerables cabeças de ganados.

Produze grandes arboles de buenas maderas para todo género de embarcaciones y edificios, que no solo con ellas, sino tambien con muy bueua piedra de que este sitio abunda se pueden edificar.

Están sus orillas pobladas de todo género 
de caça, verdad es, que el pescado en este Rio no es tanto como en el de las Amazonas, á causa de ser sus aguas tan claras, si bien en lagos que la tierra adentro haze, siempre se coge á manos llenas.

Tiene en su boca buenos sitios para fortalezas, y mucha piedra para fabricarlas, con que se podrá defender la entrada al enemigo que quisiere salir por él al principal.

Aunque yo juzgo, que no en este parage, sino muchas leguas más adentro, en el braço que desemboca al Rio grande, que ya dixe, desagua en el Occéano, es donde màs seguramente se deuiera poner toda defensa, con que quedaua del todo cerrado el paso al enemigo, para todo este nueuo mundo, que sin duda codicioso ha de intentar en algun tiempo.

No me atreuo á afirmar, si el Rio grande, en quien desemboca este braço del Negro, es dulce ó el Felipe, aunque mucho me inclino á este segundo, segun buenas demarcaciones, pues este es el primer Rio de consideraciou que pasadas algunas leguas, entra en el mar despues del Cauo del Norte; lo que puedo de. terminadamente asegurar, es, que en ninguna manera es el Orinoco, cuya principal boca cae enfrente de la Isla de la Trinidad, más de cien leguas más abaxo de donde desagua el Rio de 
Felipe, por el qual salió á la mar del Norte Lope de Aguirre, y pues él lo nauegó, podrá tambien otro qualquiera entrar, por donde vna vez se abrió camino.

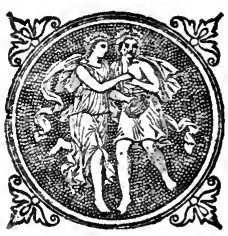




\section{NVMERO LXVI}

Intentan los Portugueses entrarse por el Rio Negro.

( ITUADA estaua la Armada Portuguesa (D) de buelta de viaje, en la boca del Rio Negro, á los doze de Octubre de seiscientos y treinta y nueue, quando considerándose los Soldados ya como á las puertas de sus casas, y boluiendo los ojos no sobre los acrecentamientos que traian, que esos eran ningunos, sino sobre las pérdidas que en espacio de más de dos años que auian andado en este descu. brimiento, auian tenido, que no eran pocas.

$\mathrm{Y}$ enterados por otra parta que los seruicios hechos á su Magestad en estas conquistas ninguna satisfaccion auian de tener en tierras donde los que más sangre han derramado en semejantes ocasiones, están oy aniquilados, y 
muriendo de hambre, por no poder parecer delante de quien los pudiera premiar.

Determinaron atraer á su voluntad la de el Capitan Mayor, persuadiéndole que ya que su pobreza les obligaua á buscar algun remedio con qne poder pasar, y las noticias de los mu chos esclauos que en lo interior deste Rio Negro poseian los naturales, ofrecía la ocasion en la mano no permitiesen dexarla pasar sin aprouecharse della, dando orden de que la gente siguiese esta derrota, pues con los muchos esclauos que deste Rio se sacase, cuando no lleuasen otra cosa, serian bien recebidos de los del Pará, y sin ellos sin duda serían tenidos por hombres para poco, pues pasando por tantas y tan diferentes Naciones, y auiendo encontrado tantos esclauos, se salían con las manos vacías; y más hauiendo hombres en estas Conquistas que á las puertas de sus casas saben hazer esclauos de que se siruen.

Muestras daua el Capitan Mayor de quererles dar gusto, quizá porque ellos eran muchos, y él solo, y así dió permiso de que se pusiesen velas en las embarcaciones, porque el viento en popa fauorable para la entrada las pedía.

Alboroçados estauan todos con esta determinacion, y nadie se prometía menos que mucho número de esclauos, y persona hubo que 
no se contentaua él solo si no llegauan á trescientos los que le tocasen de su parte.

Cuydado y no pequeño me pudiera dar esta resolucion, á no conozer el noble ánimo de nuestro Caudillo, que desinteresado de semejantes empleos, estaua yo muy confiado de que seguiría en primer lugar lo que fuese en servicio de ambas Magestades.

Con esta confiança, despues de hauer dicho Misa, recogiéndome aparte con mi compañe. ro, deseoso de por todas vias impedir intentos tan descaminados, hizirnos el papel siguiente.

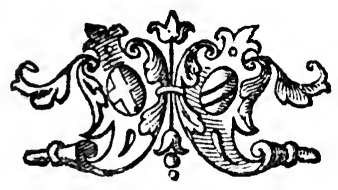




\section{NVMERO LXVII}

Requerimiento hecho al exército.

$5]$ OS Padres Christoual de Acuña y Andres de Artieda, Religiosos de la Compañía de Iesús, personas á quienes el Rey nuestro señor, por vna Real prouision despachada por su Real Audiencia de la Ciudad de San Francisco del Quito, en los Reynos del Perú, á veinte y quatro dias del mes de Enero deste presente año de mil y seiscientos $y$ treinta $y$ nueue, manda, y encarga, que auiendo venido en compañía desta armada Portuguesa por todo este gran Rio de las Amazonas, nueuamente descubierto, tomemos noticia suficiente, y la más clara que ser pueda, de las naciones que en él habitan, rios que se le juntan, y lo demás necesario para que en el Real Consejo 
de las Indias, se haga pleno concepto desta empresa, y que hauiéndolo hecho así con la mayor breuedad posible pasásemos á España á dar quenta á su Magestad de todo, sin que perrona alguna nos pueda impedir la execu. cion de todo lo referido.

Como más largamenta constará por la dicha Real prouision, que en nuestro poder viene, y siendo necesario estamos prestos para mostrarla à todos, como la hauemos hecho á algunas de las principales Cabeças deste exército.

Al presente haviendo entendido por dicho de muchos, y por las velas que se disponen para la nauegacion, que el Capitán Mayor Pedro Texeira, y los demàs Capitanes, y Oficiales mayores desta dicha armada, en cuya compañía venimos por mandado de su Magestad, intentan dilatar más el viage entrándose por el Rio Negro, en cuya boca al presente nos hallamos, con desinio de rescatar piezas esclauas dél, para lleuarlas por tales á svs haziendas del pará y Marañon, como acostumbran hazer en todas las entradas que desde el dicho Pará ha. zen á los naturales que habitan en sus con. fin es.

Y porque en esto se ha de gastar forzosamente mucho tiempo, á dicho de personas ex- 
perimentadas en semejantes entradas, $y$ ha de auer otros muchos inconuenientes.

Por acudir á la obligacion que nos corre, y para descargo nuestro ante la Real persona de su Magestad en nombre suyo, hablando con el acatamiento deuido, requerimos al Capitan Mayor Pedro Texeira, al Coronel Benito Rodriguez de Oliuera, al Sargento Mayor Felipe de Matos, á los Capitanes Pedro de Acosta y Pedro Bayon, y á los demás Oficiales viuos, que al presente se hallan gouernando cste exército en la boca deste Rio Negro.

Que por quanto ya su Magestad tiene noticia, por la Real Audiencia de la Ciudad de Quito, y por su Virey del Perú, del despacho de nuestras personas para los fines de susodi. chos, y de la breuedad con que se esperaua aúamos de llegar á su Real presencia, pues segun el dicho Capitan Mayor Pedro Texeira, y otros muchos de su compañía aseguraron á los señores de la dicha Real Audiencia de Quito, que auíamos de estar en el Pará dentro de dos meses y medio, de aquí á seis dias se cumplirán ocho meses, que salimos de dicha Ciudad de Quito, y aun faltan seiscientas leguas, desde este puerto al de Pará, de cuya dilacion pueden resultar muchos y graues inconueuientes. Como son: el dilatar su Magestad la 
fortificacion deste Rio, que tantos años há desea se descubra, esperando la breuedad con que nosotros hauíamos de llegar con las informaciones dél, y en el interin apoderarse el enemigo de sus principales entradas, cosa que resultará gran perjuizio á su Real Corona.

$\mathrm{Y}$ juntamente tan buenos y esforçados $\mathrm{Ca}$ pitanes, como aquí van, harán sin duda con tantas dilaciones grande falta á la fortaleza del Parà, á donde si el enemigo llegase, estando ellos ausentes, sería muy cierta su pérdida.

Demás desto, los Indios deste Rio Negro, donde se pretende entrar, son á juizio de todos gente muy belicosa, y de arco y flecha heruada con que nos podrán hazer mucho daño, y más viendo la poca fuerça de los Indios a migos, que nos han quedado; muchos de los quales están enfermos, y otros son muchachos sin experieneia de guerra, y todos á vna mano con ningun gusto de hazer la dicha entrada, de que puede resultar la total perdicion deste exército, fuera de que yendo con poco gusto podrá ser que se nos huyan, como lo han hecho los más de los que salieron del Pará, y más viéndose ya á las puertas de sus casas.

Aquí añadimos que los esclauos que se pretendan sacar, ay mucha dificultad si se puede hazer con buena conciencia (exceptos los 
que fuesen necesarios para lengvas) porque esta tierra es nueua, y aunque aya cédulas de su Magestad (como se dize) para sacar esclauos, esto es en la jurisdicion circunuezina del Pará y Marañon y con las demás calidades que se requieren; y estos deste rio no se sabe á qué jurisdicion pertenezcan.

$\mathbf{Y}$ dado caso que ninguna de las dichas ra. zones haga fuerça, y que se consiguiese el fin que de la dicha jornada se desea, que es sacar gran cantidad de esclauos, estos mismos, por las pocas fuerças que para guardarlos, y defendernos dellos tenemos al presente, podrá ser que sean la total ruina y destruccion de todos.

Por todo lo qual, y por lo demás que ofrecerse pudiere en desservicio de las dos Magestades Diuina, y humana, y perjuizio de la sal uacion de tanta inmensidad de almas como ay en este Rio.

De nueuo vna y otra vez boluemos á requerir al dicho Capitan Mayor Pedro Texeira, Coronel; Sargento Mayor, Capitanes y Oficiales viuos que al presente gouiernan este exército, que no dando lugar á dilaciones, que no sean del seruicio de Dios, y de su Magestad, con toda la breuedad se procure que prosigamos nuestro viaje del Pará, para de allí pasar á Es- 
paña, á cumplir con el fin y obligaciones de nuestra legacia, y se pueda acudir con brevedad, teniéndolo así su Magestad por bien, á la saluacion de tantas almas como se han descubierto en este nueuo Mundo, que miserables yacen en la sombras de la muerte.

Y si lo dicho no fuese suficiente para obligar á que todos juntos prosigamos nuestro viage con la dicha breuedad, requerimos de nueuo con la Real prouision que para ello traemos al dicho Capitan Mayor Pedro Texeira, y á los demás Oficiales del exército, que para ello tubieren mano, quedándonos el auio necesario, y todo buen pasage para resguardo de nuestras personas, se nos permita proseguir sin detencion nuestro viage, que aunque sea con riesgo de enemigos, lo posponemos todo, por cumplir con lo que su Magestad nos manda en su Real Prouision.

Y lo contrario haziendo, protestamos de todos los daños é inconuenientes que de la dilacion que hubiere en la dicha jornada se siguieren, y de dar quentá dello al Real Consejo de las Indias, y á su Real persona del Rey nuestro Señor, como se nos manda lo hagamos.

Y vltimamente para resguardo de nuestras personas, y muestras de que deseamos cvmplir 
efectiuamente con lo que somos mandados; Pedimos se le ordene al Escriuano nombrado deste exército, nos dé testimonio de todo lo que en este requerimiento se contiene, y de lo que á él nos fuere respondido. ct

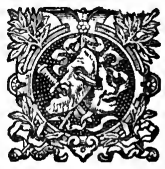




\section{NVMERO LXVIII}

Prosigue el viage, y del Rio de la Madera.

Capitan Mayor, alegrándose él mucho de tener ya quien se pusiese de su parte, y reconociendo la fuerça de las razones, mandó al instante recoger las velas, cesar con las prevenciones, y disponer para que el siguiente dia, boluiendo á desembocar por la boca del Rio Negro, prosiguiésemos todos por el de las Amazonas abaxo nuestro viage.

Hizímoslo asi, y á las quarenta y quatro le. guas dimos con el gran Rio de la Madera, llamado asi de los Portugueses, por la mucha y gruesa que traia quando le pasaron, pero su nombre propio entre los naturales que le habi$\tan$ es Cayarr.

Desciende de la vanda del Sur, y segun lo 
que aueriguamos, se forma de dos caudalosos rios que algunas leguas adentro se le juntan; por los quales, segun buenas demarcaciones, y segun las señas de los Tupinambás, que por él baxaron, es por donde más en brene que por parte alguna se ha de descubrir salida á los más cercanos rios de la comarca de Potosí.

De las naciones deste rio, que son muchas, las primeras se nombran Zurinas, y Cayanas, y luego se van siguiendo los Vrutihans, Anamaris, Guarinumas, Curanaris, Erepunacas, y Abacatis.

Y desde la boca deste rio, corriendo por el de las Amazonas abaxo le pueblan los Zapucayas, Vrubutingas, que son muy curiosos en labrar cosas de madera; tras estos se siguen los Guaranaguacas Maraguas, Quimaus, Burais, $\mathrm{Pu-}$ nouys, Oreguatus, Aperas, y otros cuyos nombres no pude con certeza aueriguar.

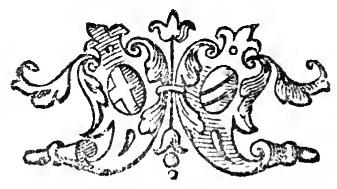




\section{NVMERO LXIX}

Isla grande de los Tupinambás.

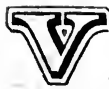

EINTE y ocho leguas de la boca deste Rio, caminando siempre por la mesma vanda del Sur, está una hermosa Isla, que tiene sesenta de largo y consiguientemente más de ciento de circuito, poblada toda de los valientes Tupinambás, gente que de las conquistas del Brasil, en tierras de Pernambuco, salieron derrotados muchos años ha, huyendo del rigor con que los Portugueses les ivan suge. tando.

Salieron tan gran nvmero dellos, que despoblando á vn resmo tiempo ochenta y quatro aldeas donde estauan situados, no quedó de todos ellos ni vna criatura que no traxesen en su compañía.

C ogieron siempre á mano izquierda las fal 
das de la Cordillera, que viniendo desde el estrecho de Magallanes ciñen toda la América: y descabeçando quantos rios tributan della en el Occeano, llegaron algunos á entrarse con Es pañoles del Perú que habitauan en las cabeças del Rio de la Madera.

Estubieron con ellos algur tiempo, y porque vn Español açotó á vno, por auerle muerto vna baca, aprouechándose de la ocasion del Rio, se arrojaron todos por sus corrientes, uiniendo á dar en la Isla que al presente habitan.

Hablan estos Indios la lengua general del Brasil, que tambien corre entre casi todos los de las conquistas del Marañon, y Pará.

Dizen tambien que como salieron tantos, que no pudiendo por aquellos desiertos sustentarse todos juntos, se fueron diuidiendo en tan dilatado camino, que por lo menos será de más de nouecientas leguas, quedando vnos á poblar unas tierras y otros otras, de quienes sin duda estarán bien llenas todas aquellas Cordilleras.

Son gente de grande brio en la guerra, y bien lo mostraron los que llegaron á estos parages, donde al presente habitan, pues siendo ellos, sin comparacion, muchos menos que l os naturales deste Rio, de tal suerte les asola- 
ron, y sugetaron á todios aquellos con quienes tubieron guerras, que consumiendo naciones enteras, á otras obligaron á dexar de miedo su natural, $y$ irse peregrinos á tierras extrañas.

Vsan estos Indios de arco y flecha, que con destreza disparan.

Son de coraçones nobles y ahidalgados, si bien como ya casi todos los que al presente ay, son hijos, y nietos de los primeros pobladores, ya se van acomodando á las baxezas y ma. ñas de los de la tierra, con cuya sangre están mezclados.

Mostráronnos todos grande agasajo, dando muestras de que en breue se auían de reduzir á viuir entre los Indios a mizos del Pará; cosa que será sin duda de mucho vtil para conquistar todas las demás naciones deste Rio, si se hubiere de poblar; pues á solo el nombre de Tupinambas no ay ninguna dellas que no se rinda.

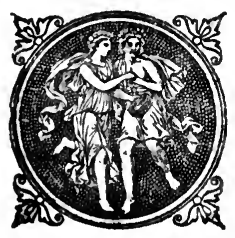




\section{NVMERO LXX}

Noticias que dieron los Tupinambás.

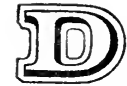

ESTOS Indios Tupinambás como de gente de más razon y que no necesitan de Intérpretes, por correr, como ya dixe, entre ellos lá lengua general, que muchos de los mesmos Portuguests hablan con eminencia, por ser nacidos y criados en aquellas costas.

Tubimos algunas notscias que aqní diré, como de gente que tiene corrido y sugeto todo lo circunuezino á su jurisdicion, se pueden tener por ciertas.

Dizen que cercanos á su habitacion, á la vanda del Sur en Tierra firme, viuen, entre otras, dos naciones, la vna de enanos, tan chicos como criaturas muy tiernas, que se llaman Guayazís, la otra de vna gente que todos ellos tienen los pies al reués, de suerte que quie $n$ 
no conociendo los quisiese seguir sus huellas, caminaría siempre al contrario que ellos. llámanse Mutayus, y sónles tributarios á estos estos Tupiuambás, de hachas de piedra para el desmonte de los árboles, cuando quieren cultiuar la tierra, que las hazen muy curiosas, y de continuo se ocupan de labrarlas.

A la vanda de enfrente, que es la del Norte, dizen que están continuadas siete Prouin. cias bien pobladas, pero que por ser gente para. poco, y que solo se sustentan con frutas, y animalillos siluestres, sin jamás sustentar guerras entre sí, ni con otros, no hazen dellos ca:o.

Tambien afirman que con otra nacion que confina con esta tubieron pazes mucho tiempo, auiendo comercio entre ellos de lo que cada una en su Prouincia abundaua, y lo principal de que los Tupinambás se proueían era de sal, que los amigos les traian por sus rescates, que afirmauan venirles de otras tierras vezinas á las suyas, cosa que si se descubriese sería de gran-

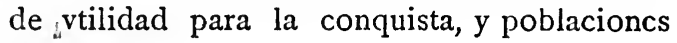
deste Rio.

$\mathrm{Y}$ quanto aquí no se halle, se ha de descubrir en grande abundancia en un rio de los que baxan de ázia el Perú; de donde el año de treinta y siete, estando ya en la Ciudad de Lima, salieron dos hombres que de lance en lan- 
ce, aportaron por aquellas partes, a cierto parage, donde baxando por vno de los rios, que en este principal desaguan, dieron con vn gran cerro todo de sal, de que los moradores tenían el estanco, sustentándose ricos, y abundantes, con las pagas que por ella recibían, de los que de más lejos la venían á contratar.

Y no es nueuo en el Perú, y en todas sus Cordilleras, tener cerros de sal de piedra excelente, pues esta es la que en todo él se gasta, sacándola de su natural con barretas azeradas, en pedaços tan grandes, que tienen á cinco, y seis arrobas cada vno.

Ocupa esta Prouincia de los Tupinambás setenta y seis leguas de largo, que feneze en vna buena poblacion que está situada en tres grados de altura, como tambien lo estaua la primera de los Indios Aguas de que ya hizimos arríáa mencion.

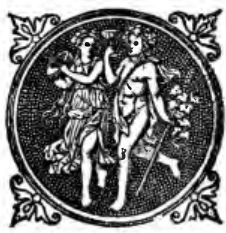




\section{NVMERO LXXI}

Dan uoticias de las Amazonas.

ON el dicho tambien destos Tupinam * bás, confirmarnos las largas noticias que por todo este Rio traíamos de las afamadas Amazonas, de quienes él tomó el nombre de sus primeros principios, no le conociendo por otro ninguno, sino por éste, todos los Cosmó. grafos, que dél hasta hoy han tratado.

$Y$ fuera cosa de admiracion que sin muy graues fundamentos, hubiera usurpado el nombre de Rio de las Amazonas, pudiéndole qualquiera dar en rostro, de que por él se quería hazer famoso, con no más razon que de vestirse de lo ageno.

No me lo persuado yo de su nobleza, ni es creible, que teniendo este gran Rio tantas grandezas de que echar mano, solo quisiese 
gloriarse del titulo que no le competía. Baxeza ordinaria, de quien no valiendo por sus braços alcanza la honra que desea, la procura mendigar del vezino.

Los fundamentos que ay para asegurar Pro. uincia de Amazonas en este Rio, son tantas, y tan fuertes que sería faltar á la fe humana, el no darlas crédito.

$Y$ no trato de las graues informaciones que por orden de la Real Audiencia de Quito', se hizieron con los naturales que le habitaron muchos años, de todo lo que en sus riueras contenia; en que vna de las principales cosas que se aseguran, era el estar poblado de vna Prouincia de mugeres guerreras, que sustentándose solạs sin varones, con quíenes, no más á ciertos tiempos tenía cohabitacion, viuían en sus pueblos, cultiuando sus tierras, y alcançan. do con el trabajo de sus manos todo lo necesario para su sustento.

Tampoco hago mencion de las que por el nueuo Reyno de Granada, en la Ciudad de Pasto, se hizieron con algunos Indios, y en particular con una India, que dixo auer ella mesma estado en sus tierras donde estas mugeres están poblabas; conuiniendo en todo con lo que ya se sabía por los primeros dichos.

Solo echo mano de lo que oí con mis oidos, 
y con cuydado auerigüé desde que pusimos los pies en este Rio. En que no ay generalmente cosa más comun, y que nadie la ignora, que dezir habitàn en él estas mujeres, dando señas tan particulares, que conuiniendo todas en vnas mesmas, no es creíble se pudiese una mentira auer entablado en tantas lenguas y en tantas naciones, con tantos colores de verdad.

Pero donde más luz tubimos del sitio donde viuen estas mugeres, de sus costumbres, de los Indios que las comunican, de los caminos por donde se entra á sus tierras, y de los naturales que los pueblan, (que es la que aquí daré) fvé en la vltima aldea donde da fin la Prouin. cia de los Tupinambás.

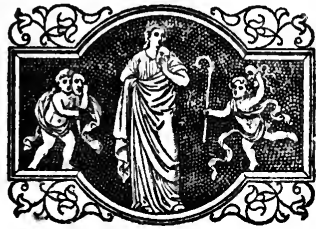


Rio de las Amazonas.

Corriendo Rio abaxo, está á la vanda
corista leguas desta Aldea, del Norte el de las Amazonas, que con nombre de Rio Canuris es conocido entre aquellos naturales.

Toma este Rio el nombre de los primeros Indios que sústenta en su boca, á quienes se siguen los Apantos, que hablan la lengua ge. neral de todo el Brasil. Tras estos están sitiados los Taguaus, y los vltimos, que son los que comunican con las mismas Amazonas, son los Guacarás.

Tienen estas mugeres varoniles su asiento entre grandes montes, y eminentes cerros, de los quales el que más se descuella entre los otros, y que como más soberbio es combatido 
de los vientos, con más rigor, á cuya causa toda la vida se muestra escaluado y limpio de yerba, se llama Yacamiaba.

Son mujeres de gran valor, y que siempre se han conseruado sin ordinario comercio de varones, $y$ aun quando estos por concierto que con ellas tienen, vienen cada año á sus tierras, los reciben con las armas en la mano, que son $\operatorname{arcos}$ y flechas, que juegan por algun espacio de tiempo, hasta que satisfechas de que vienen de paz los conocidos, y dexandolas armas, acuden todas á las canoas, ó embarcaciones de los güéspedes y cogiendo cada vna la a maca que halla más á mano, que son las camas en que ellos duermen, la lleuan á su casa, y colgándola en parte donde el dueño la conozca, le reciben por göésped aquellos pocos dias, despues de los quales, ellos se vuelven á sus tierras, continuando todos los años este viage por el mis. mo tiempo.

Las hijas hembras que deste ayuntamiento las nacen, conseruan y crian entre sí mesmas que son las que han de lleuar á delante el valor, y costumbres de su nacion, pero los hijos varones no hay tanta certeza de lo que con con ellos hazen.

Vn Indio, que siendo pequeño, aura ido con su padre á està entrada, afirmó que los hi- 
jos varones los entregaban á sus padres, quando el siguiente año voluían á sus tierras. Pero los demás, y es lo que parece más cierto por ser dicho más comun, dizen que en reconociéndoles por tales les quitan la vida.

El tiempo descubrirá la verdad, y si estas son las Amazonas afamadas de los historiadores, tesoros encierran en su comarca para enriquecer á todo el mundo.

Está la boca deste rio que pueblan las Amazonas, á dos grados y medio de altura.

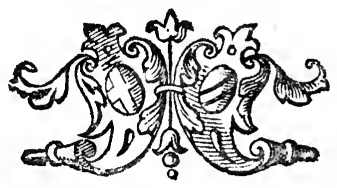




\section{NVMERO LXXIII}

Estrechura de todo el Rio.

5 (2)ASADA la boca deste Rio de las Amazonas y corriendo veinte y qualto leguas del principal, desagua á la mesma vanda del Norte, otro mediano, que se llama Vrixamina, que sale á aquel paraje, donde como ya dixe arriba, se estrecha este gran Rio, en espacio de poco más de vn quarto de legua. Donde ofrece apacibles sitios para plantar, de vna $y$ otra vanda dos fortalezas, que no solo impiden el paso al enemigo, que por parte del mar le intentare, sino que tambien, siruiendo de Aduanas, se registre en ellas todo lo que por este Rio de las Amazonas, si se poblare, serà fuerza que baxe del Perú.

Desde este paraje que está, como arriba dixe, màs de trescientas y sesenta leguas de la 
mar, se comiènça á sentir sus mareas, recono. ciéndose todos los dias crezientes y menguantes, aunque no tan á las claras como de algunas leguas más adelante. 


\section{NVMERO LXXIV}

Rio, y nacion de Tapajosos.

(ล) VARENTA leguas de esta estrechura desemboca por la vanda del Sur, el grande, y vistoso Rio de los Tapajosos, tomando el nombre de la Nacion, y Prouincia que sustenta en sus orillas, que es muy poblada de Bárbaros, en buenas tierras, y de abundantes mantenimientos.

Son estos Tapajosos, gente de brios y que les temen muchas vezes de las Naciones circunuezinas, porque vaan de tal ponçoña en sus flechas, que con solo llegar á sacar sangre, quitan sin remedio la vida.

$\mathrm{Y}$ á esta causa los mesmos Portugueses les rezelaron la comunicacion por mucho tiempo, deseando por bien atraerles á su amistad, á que nunca salieron del todo, porque les obligauan 
con ella á dexar su natural, y venirse á poblar entre los ya pacificos, cosa que sienten mucho estas Naciones. Si bien en sus tierras recibían con gran agasajo á los nuestros, como lo experimentamos aloxados junto á vn pueblo suyo, de más de quinientas familias, de donde en todo el dia no cesaron de venir á rescatar gallinas, patos, amacas, pescado, harinas, frutas y otras cosas; con tanta seguridad, que mujeres, y niños, no se apartauan de nosotros, ofreciendo que si los dexasen en sus tierras, viniesen muy en horabuena á poblarlas los Portugueses, que los recibirfan y seruirian de paz toda la vida.

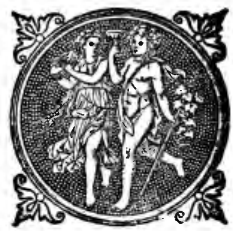




\section{NVMERO LXXV}

Opresion que hizieron los Portugueses.

O bastaron los humildes ofrecimientos
de estos Tapajosos, para personas tan interesadas como son las de estas conquistas, y que solo emprenden dificultades con la codicia de los esclauos que esperan rescatar, para que fuesen admitidos, ó por lo menos puestos en toda razon y conueniencia. Si no que sospechando tenfa esta Nacion muchos en su seruicio trataron con toda fuerça, á título de rebeldes, irles á ofrecer cruda guerra.

Esta se estaua disponiendo quando llega mos de nuestra jornada al fuerte del Destierro, donde se juntaua la gente para tan inhumana faccion.

$\mathrm{Y}$ aunque por los mejores medios que pude, la procuré, ya que no impedir, á lo menos 
suspender hasta que hubiese nueua orden de Su Magestad, el Sargento mayor del Estado, Cabo, y Caudillo de todos, que era Benito Maziel, hijo del Gouernador me dió su palabra de que no proseguiría con su intento, hasta tener auiso de su padre.

Apenas bolui la cabeça, quando con la más gente que pudo, en vna lancha con piezas dé artillería y en otras embarcaciones menores, dando sobre ellos de improuiso, les ofreció cruda guerra. si no querían buena paz.

Esta admitieron luego ellos con buena voluntad, como siempre la auían ofrecido, rendidos á todo lo que quisiesen disponer de sus personas.

Mándales entregar todas las flechas herbadas de ponçoña, que tenían, que era de lo que màs se podía rezelar, á que los miserables obedecieron luego al punto; y viéndolos ya desarmados cogen gran cantidad de Bárbaros y enciérranlos todos en vn corral con suficiente guarda, sueltan los Indios amigos que lleuauan, que para hazer mal cada vno es vn diablo desatado, que en breue tiempo saquearon todo el pueblo, sin dexar cosa en él que no asolasen; aprovechándose, como me contó quien lo auía visto, de las hijas y mugeres de los afligidos presos, á vista de sus mesmos ojos: y haziendo 
cosas que me aseguró esta persona, que es bien antigua en aquellas conquistas, que por no verlas, no solo dexaría de comprar escla. uos, pero qae aun daría de balde los que poseia.

No paró aqui la crueldad de los Portugueses, que como iba embuelta en codicia de es. clauos, no quedaba satisfecha hasta uerse se. ñora dellos.

Amenazan los Indios encorralados, y teme. rosos, atemorízanles de nueuo con nueuos rigores; para que ofrezcan esclauos, asegurándoles que con esto no solo quedarian libres, sino amigos suyos y cargados de herramientas y lienço de algodon que les darían por ellos.

¿Qué auian de hazer los miserables?

Presos ellos, quitadas las armas, saqueadas sus casas, oprimidas sus mugeres, y hijos, sino rendirse á todo lo que ellos quisiesen hazer.

Ofrecen mil esclauos, enuían por ellos, que con el alboroto de la tierra se auían puesto en cobro, y no pudiendo juntar más de pocos más de doscientos, entréganlos, y con palabra de que cumplirán los restantes, dexan libres á los que por verse así ofrecieran sus mismos hijos por esclauos, como muchas vezes ha acontecido. Despachan todos estos al Marañon y Pará, que yo vi con mis ojos, y saboreados de la presa, 
disponen luego otra mayor entronacion más á dentro del Rio de las Amazonas, donde serán sin duda mayores las crueldades, porque van menos personas de valor, que puedan ir á la mano del que lleua el carjo de todos. Con que quedará el Rio tan alborotado, que quando su Magestad quiera que se pacifique, habrá de te: ner muy grandes dificultades, siendo asi que como yo le dexé quando salí dél, á muy poca costa se pudiera hazer.

Estas son las conquistas del Pará, este es el trato de que se sustentan, y esta la justísima. causa porque todos andan arrastrados, sin tener vn pan que comer.

$\mathrm{Y}$ si n॰ fuera por los seruicios que han hecho á entrambas Magestades Diuina, y humana en resistir valerosamente al enemigo Olandés, que varias uezes ha uencido en aquella tierra, ya nuestro Señor la tubiera asolada.

Boluiendo, pues, á lo de los Tapajosos, y al famoso rio que baña sus riberas, digo que es de tan buen fondo, que por él arriba muchas leguas, subió en tiempos atrás vna nao Inglesa de gran porte, que pretendiendo hazer asiento en esta Prouincia y entablar cosechas de tabacos con los naturales, les ofrecieron buenos partidos; pero ellos dando de improuiso en los Ingleses no aceptaron otro, que matar á 
los que pudieron auer á las manos, y aprovechándose de sus armas, que oy en dia tienen, les hizieron dexar la tierra más aprisa de lo que aúan venido, excusando la gente que quedó en la nao, con hacerse luego á la vela, otro encuentro semejante, en que del todo quedasen consumidos.

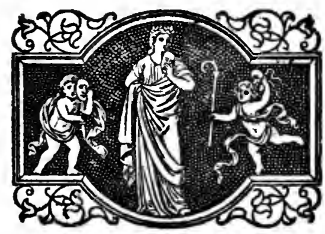




\section{NVMERO LXXVI}

\section{Curupatuba.}

A pocas más de quarenta leguas de la $\checkmark$ Goca del Rio de los Tapajosos, está el de Curupatuba, que desaguando en el principal de las Amazonas, á la vanda del Norte, da nombre á la primera poblacion, ló Aldea, que de paz tienen los Portugueses á devocion de su Corona.

No muestra este rio ser muy caudaloso de aguas, pero si de tesoros si los naturales dél no nos engañan; los quales afirman que subiendo por este rio, que ellos llaman con nombre de Iriquiriqui, camino de seis dias, se halla gran cantidád de oro, que lo cogen en las orillas de vn riacho pequeño, que baña las faldas de vn mediano cerro, llamado Iaquaracuru.

Dicen tambien que cerca de este está otro 
sitio cuyo nombre es Picuro, donde han sacado otras veces otro metal más duro que el oro, de color blanco, que sin duda es plata, de que labraron antiguamente hachas, y cuchillos, pero que viendo no ser de prouecho, y que luego se mellauan, no hicieron más caso dél.

Ay en este mismo distrito dos sierras; que la vna, segun las señas que dan los Indios, es de azufre, y de la otra, que se llama Paraguaxo, aseguran que quando le da el Sol, y tambien en las noches claras, resplandece de suerte, que toda ella parece esmaltada de rica pedreria; y de quando en cuando reuienta con grandes estruendos, muestra cierta de que en si encierra piedras de mucho valor.

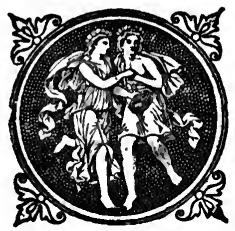




\title{
NVMERO LXXVII
}

\author{
Rio Ginipape.
}

S $\begin{aligned} & \text { O promete menos tesoros, segun noti- } \\ & \text { cias comunes, el rio de Ginipape, que }\end{aligned}$ corriendo por la misma vanda del Norte desemboca en el de las Amazonas, á las sesenta leguas más abaxo de la Aldea de Curupatuba. De quien dizen los Indios tanto, del mucho oro que en sus orillas se puede recoger, que si ello es así, solo este rio dexará atrás con sus aueres, los máyores de todo el Perú.

Las tierras que este rio riega, son de la ca. pitanía de Benito Maziel Pariente, Gouernador del Marañon, que fuera de ser ellos solos, más que toda Fspaña junta, y auer en ellas muchas noticias de minas, son en sí por la mayor parte del mejor migajon, y para rendir mayores 
frutos, y prouechos que cuantas ay en este inmenso Rio de las Amazonas.

Están todas á la vanda del Norte; contienen en sí grandes Prouincias de Bárbaros; y lo que es más de estima, encierran debaxo de su jusisdicion, las afamadas $y$ dilatadas Tierras del Tucujú, tan suspirado, y tantas vezes poblado, aunque con su daño, del enemigo Olandés, que reconociendo en ellâs las mayores comodidades del mundo, para enriquecer sus moradores jamás las puede oluidar.

Son no solo apropósito para grandes cosechas de tabacos, y capaces de las mejores de lo descubierto para muchos ingenios de açúcar, y agradecidas con sus mantenimientos, á qualquier pequeño cultiuo, que en ellas aya, sino tambien de excelentes campiñas, que con abundantes pastos sustentarán infinitos ganados.

En esta Capitanía, seis leguas de donde desagua Ginipape, el Rio arriba de las Amazo. nas, está un fuerte de Portugueses, que llaman del Destierro, con treinta soldados y algunas piezas de artillería; que para lo que toca á defender el Rio, no sirue de nada, autorizando solo la dicha Capitanía, y teniendo en algun temor los Indios que de ella se van reduziendo.

Este fuerte quitó Benito Merziel con braço 
de Gouernador del Curupá, que cae treinta leguas más abaxo, donde por muchos años estuvo situado en muy buen sitio, y donde las naos enemigas venían á reconocer de ordinario.

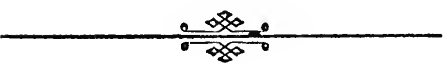




\title{
NVMERO LXXVIII
}

\author{
Rio Paranaiba.
}

IEZ leguas más abaxo del rio Ginipape
sale á la vanda del Sur, uno muy visto so, y caudaloso, que con dos leguas de boca, entra rindiendo parias al principal, llámanle los naturales Paranarba; están en sus riberas algunas poblaciones de Indios amigos, que teniendo asiento en sus primeras entradas, obedecen las órdenes de los Portugueses que los gouiernan. $\mathrm{Y}$ en lo más interior viuen otrcs muchos, de quienes, y de lo demás que este rio contiene, aun no hay suficientes noticias. 


\title{
NVMERO LXXIX
}

\author{
Rio Pacaxa.
}

(5) ESDE dos leguas más abaxo del Ginipape comiença á dividirse en grandes braços el Rio de las Amazonas que causan la multitúd de Islas, que hasta desembocar en el Occeano en él se conocen, pobladas todas de diferentes Naciones y lenguas; si bien las más entienden lá general de aquella costa.

Son estas İslas tantas, y las Naciones que las auitan tan diuersas, que solo para ellas era menester vna nueua historia.

Con todo nombraré aquí álgunas de las más conocidas, como son las de los Tapuyas, Anaxiates, Mayanafes, Engaibas, Bocas, Juanes, y las de los valientes Pacaxás, que en las riberas del Rio, de quien tomaron nombre, que sale ochenta leguas del Paranarba, á la mesma 
vanda, tienen su habitacion, $\mathrm{y}$ en tanto número asi de aldeas como de moradores, segun afirman los Portugueses que allá estuviron, como qualquiera otra de las más pobladas de nuestro Rio.

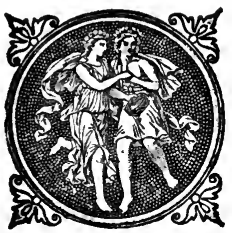




\section{NVMERO LXXX}

Poblacion de Conmutá.

A quarenta leguas del Pacaxá está situa5 da la aldea del Conmutá, que en aquellas conquistas fué en tiempos pasados de grande fama, así por sus muchos moradores como por ser alli donde de ordinario se aprestauan las armadas, quando auían de hacer sus correrías.

Pero ya no le ha quedado ni gente, por auerse mudado á otras tierras, ni mantenimientos, por no auer quien los cultiue, ni otra cosa. más que el sitio antiguo eon pocos naturales siempre bueno, y que con su apacibilidad y linda vista, está brindando hermosura y comodidades á los que le quisieren poblar. 


\section{NVMERO LXXXI}

\section{Rio de los Tocantines.}

A las espaldas del Conmutá desemboca 5 el rio de los Tocantines, que aunque en aquellas partes tiene nombre de rico, y al parecer con âlgunos encarecimientos, ninguno ha conocido su caudal, sino solo el Francés, que quando poblaba sus costas, cargaba naos de solá la tierra que de sus orillas sacaba, para beneficiarla en la suya, enriqueciéndola. Sin atreverse jamas á mostrar tales tesoros á los Bárbaros, que en el habitan, rezeloso de que haziendo de ellos la estima que era razon, sin duda los defenderían con las armas para no se dexar desposeer de tantas riquezas.

A las cabeçadas deste Rio aportaron ciertos soldados Portugueses, que desde Pernambuco, con vn sacerdote en sn compañia, atrauesaron 
todas las faldas de la Cordillera, en busca de nuevas conquistas, y queriendo por él abaxo. navegar hasta darle fin, ellos le tuvieron desastrado á manos de los Tocantines, en cuyo poder se halló no ha muchos años el Caliz, con que el buen Sacerdote les dezía Misa en sus. peregrinaciones.

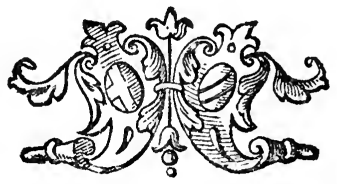




\title{
NVMERO LXXXII
}

\author{
El Pará.
}

jREINTA leguas del Conmutá tiene su asiento la fortaleza del gran Pará, po blada y gouernada por Portugueses.

Ay en ella Capitan Mayor, que es sobre todos los de aquella Capitanía, y á quienes están sugetos otros tres Capitanes de infantería, que de ordinario asisten con sus compañías, para la defensa de aquella plaça.

Si bien así estos como aquel, en todo obedecen al Gouernador del Marañon, que tiene su asiento más de ciento y treinta leguas la Costa arriba ácia el Brasil, de que hazen graues inconuenientes en el Gobierno del Pará, que si este rio se puebla será fuerça quede por dueño dél, como quien tiene en su mano la llave de todo. 
$Y$ aunque es verdad, que el sitio donde al presente está no es, á juizio de muchos, el mejor que se podía escoger, auiendo de ir este descubrimiento adelante, será fácil mudarle á la Isla del Sol, catorce leguás más á la mar; puesto, en quien todos tienen los ojos, por los muchos cómodos que ofrece para la vida humana así de capacidad y bondad en la tierra Para el sustento de la poblacion, como tambien por la comodidad de los nauíos que á ellas aportasen, que en una ensenada, segura de todos contrastes, pueden estar todo el tiempo que quisieren, $y$ quando se hubiesen de hazer á la vela, con la primera plena mar quedan desembocados de todos los baxos que hazen dificultosos éstos puestos, que no es pequeña comodidad.

Es esta Isla de más de diez leguas de zir. cuyto, de buenas aguas, mucho pescado de la mar, y del rio, gran multitud de cangrejos, sustento ordinario de los Indios, y gente pobre; $y$ al presente es de las principales á donde van del Parà de ordinario á cazar la carne que han menester para su sustento.

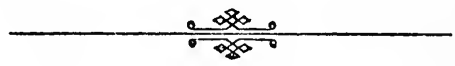




\section{NVMERO LXXXIII}

Entra en el mar el Rio de las Amazonas.

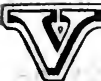

EINTE y seis leguas de la Isla del Sol, debajo de la línea Equinocial, esplayado en ochenta y quatro de boca, teniendo por la vanda del Sur al Zaparará, y por la contraria al Cabo del Norte, desagua en el Occeano el mayor piélago de aguas dulces que ay en lo descubierto, el más caudaloso Rio de todo el Orbe: el Fénix de los Rios, el verdadero Marañon, tan suspirado, y nunca acertado de los del Perú, el Orellana antiguo, y para dezirlo de una.vez, el gran Rio de las Amazonas.

Despues de auer bañado con sus aguas mil trescientas y cinquenta y seis leguas de longitud: despues de sustentar en sus riueras infinitas Naciones de Bárbaros; despues de fertilizar inmensas tierras; y despues de auer pasado por 
el ríñon de todo el Perú, y como canal principal, recogido en sf lo mejor, y más rico de todas las vertientes.

Este es en suma el nueuo descubriuriento deste gran Rio, que encerrando en sí grandiosos tesoros à nadie escluye; más antes, á todo género de gente combida liberal á que se aproueche de ellos.

Al pobre ofrece sustento, al trabajador, satisfaccion de su trabajo: al mercader, empleos; al soldado, ocasiones de valer; al rico, mayores acrecentamientos; al noble, honras; al poderoso, estados; y al mesmo Rey vn nueuo Imperio.

Pero quienes más interesados se han demostrar en esta conquista, son los zelosos de la honra de Dios, y bien de las almas, pues tanta multitud dellas, está ya clamando, por fieles Ministros del Santo Evangelio, para que con la claridad dél, se les auyenten las somcras de la muerte, en que ha tanto tiempo que miserables yacen.

$Y$ nadie se escuse desta empresa, pues para todos hay campo descubierto, y por muchos trabajadores que se conduzgan la mies será mayor; y siempre necesitará esta nueua Viña, de nueuos y feruorosos obreros para que la cultiuen; basta sugetarla toda debaxo de las 
llaues de la Iglesia Romana. A que sin duda nuestro Grande, y Católico Rey Filipo Quarto, que Dios nos guarde muchos, y felizes años, acudirá de su parte, con la liberalidad que acostumbra en lo temporal, para el sustento de Ministros tales. Y la Santidad de nuestro muy Santo Padre Vrbano Octauo de gloriosa memoria, como Padre, y Cabeça que oy es de la Iglesia, se muestrá en lo espiritual no menos liberal y benigno: Teniendo á grande dicha que en sus tiempos se abra anchurosa puerta, para reduzir al rebaño de la Iglesia de vna vez, más Nociones juntas, y más populosas, de quantas en toda la América, desde sus primeros principios, se descubrieron.

Laus Deo Virginique Matri. 


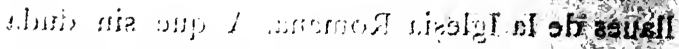

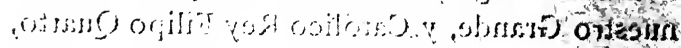

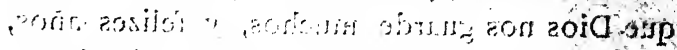

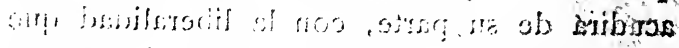

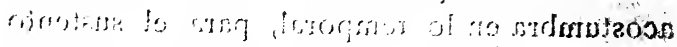
".

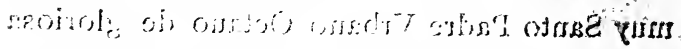

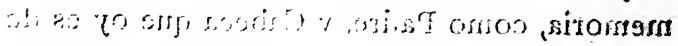

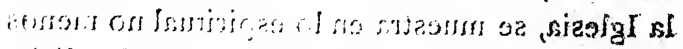

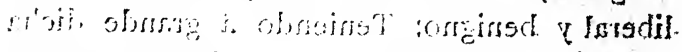

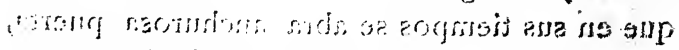

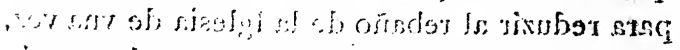

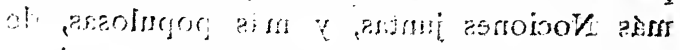

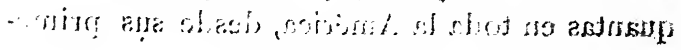

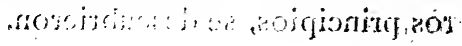

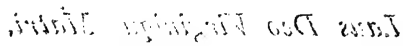




\section{MEMORIAL}

PRESENTADO EN EL

REAL CONSEJO DE LAS INDIAS, SOBRE

EL DICHO DESCUBRIMIÉNTO

DESPUES DEL REUELION

DE PORTUGAL 



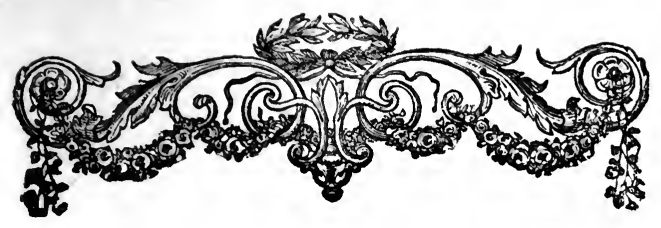

\section{SEÑOR:}

Christoval de Acuña, Religioso de la Compañia de Iesús, que vino por orden de vuestra Magestad, al descubrimiento del gran Rio de las Amazonas.

Cuydadoso siempre de los mayores aumentos de su Real Corona, y rezeloso de que acontecimientos menos fauorables, vistos á nuestras puertas, ahoguen y impidan el lucimiento de sus afectuosos servicios. Dize, que aunque es verdad, que la principal puerta de aquel nueuo mundo descubierto, para más en breue començar á gozar de los prouechosos, y ricos frutos, que liberal ofrece, es la boca principal dél, por la parte que desagua en el Occeano, de las Costas del Brasil, sujeta á Portugueses, 
y por eso menos sazonada, para que de presente se procure esta entrada.

Pero que no por eso deue Vuestra Mages. tad desistir, ni dilatar la profesión de este gran gran Rio, pues con más facilidad y muchos menos gastos lo podrá hazer por la Provincia de Quito, en los Reynos del Perú, por las mesmas entradas por donde él, y sus compañeros baxaron.

De que resultarán sin duda grandes servicios de Dios nuestro Señor, y de Vuestra Magestad, y se euitarán, no menos inconuenientes, que de no executarlo en breue, en breuese experimentarán, y quizá sin remedio.

Lo qual se podrá efectuar sin gastos considerables de la Real Hazienda, con solo embiar orden á la Chancilleria de Quito, para que capitule las entradas que más conuenga, por los rios que en su jurisdiccién desaguan en este principal, con algunas de las muchas personas, que á su costa se ofrezen á hazer estas conquistas, solo por los intereses que de ella se sacan, como son las encomiendas de los Indios, repartir tierras, proueer oficios, y otros semejantes.

Cometiendo juntariente lo espiritual de ellas, en lo tocante á la conuersion, y enseñança de los naturales, á los Religiosos de la Com. 
pañía de Iesús, cuyo instituto es este, y á que con no pequeño título, en este particular des. cubrimiento, pueden mostrar algun derecho, pues sus hijos, no solo han aclarado, á costa de sus trabajos, y desvelos, y aun de muchos ducados, las sombras de un nueuo y dilatado Imperio, que bañado de este grandioso Rio, ofrece crecidos aumentos á la Real Corona de Vuestra Magestad, sino que por posesion de más de quarenta años, adquirida con la sangre del dichoso Padre Rafael Ferrer, derramada por los naturales, á quienes en los principios deste Rio predicaua, se les deue.

Continuando el no perder este derecho los Padres de la Compañía, que por Santiago de las Montañas, ha años que cultiuan con su doctrina los principales raudales de esta nue. ua conquista; que para continuar se necesita en aquella Prouincia de Quito, nueuos obreros de Europa, que les ayuden en tan copiosa mies.

A que sin duda acudirá Vuestra Magestad con la piedad que siempre, y la liberalidad que pide la necesidad extrema de tanta inmensidad de Naciones diferentes,

De que resultarán los prouechos siguientes:

Lo primero, y que siempre lo es en el Chriistanissimo pecho de Vuestra Magestad, 
darán sin más dilaciones, principio con la conuersion de un nueuo mundo de infieles que miserables yacen en la sombra de la muer. te: obra tan del seruicio de Dios, que no se puede ofrecer otra que más le agrade, y tal que por ella se dará por obligada á establecer con perpetuidad la Corona de Vuestra Magestad, y de nuevo dilatarla á mayores Imperios.

Lo" segundo, ahorráranse muchos gastos, que como forçosos, eran inescusables, si esta conquista se hubiera de hazer como se intentaua, por la boca del Rio: en conduzir soldados, preuenir embarcaciones, juntar pertrechos, $y$ disponer todo lo necesario para formar nuéuas poblaciones, que sin duda auran de ser muchas.

Lo qual todo se escusa con mandar que se comienze esta conquista por las entradas de Quito, pues los pärticulares á quienes se cometieren, harán con gusto todo el gasto, y solo necesitarán para lo espiritual della, de Obreros, y Ministros aptos del Evangelio, que Vuestra Magested enuie de España por la extrema necesidad que de tllos hay en aquellas partes.

Eo tercero, començará Vuestra Magestad á poseer y gozar de lo que todos los Señores Reyes sus predecesores, desde el Señor Em. 
perador Carlos Quinto que Dios aya, digno vis · abuelo de Vuestra Magestad, desearon, y con no pocos gastos, y diligencias procuraron sugetar á su Real Corona.

Para lo qual el año de mil y quinientos, $y$ quarenta y nueue, el mesmo señor emperador Carlos Quinto, mandó dar á Francisco de Orellana tres nauíos con suficiente gente, y pertrechos, para que en su Real nombre tomase posesion de este ǵran Rio de las Amazonas, (que nueue años antes él mesmo auía nauegado,) por los muchos vtiles que de executarlo así se esperauan; si bien las tormentas, y muerte de casi todos los soldados, les obligaron á que reduzidos á una breue embarcacion arribasen á la Margarita, donde con su mal suceso, cesaron las esperanças que de muchos buenos se prometia España, si les hubiera corrido mejor fortuna.

Y Vuestra Magestad desde los primeros principios de su Reynado, que sea por muchos, y felicísimos años, ocupó su desuelo en la consecucion de esto mesmo, cometiendo la execucion de este descubrimiento á varias persanas, como consta en sus Reales Cédulas, despachadas en esta conformidad, por los años de veinte $y$ vno, $y$ veinte $y$ seis, $\mid y$ treinta y quatro. 
La de veinte y vno, despachada á la Real Audiencia y Chancillería de Quito, para que se capitulasen las condiciones que para el dicho descubrimiento fuesen conuenientes, con el Sargento Mayor Vicente de Reyes Villalobos, Gouernador, y Capitan Gentral en aquella sazon de los Quixos, jurisdicion de Quito, que por llegarle sucesor en $\epsilon 1$ gouierno, no tubo efecto.

La de veinte y seis, despachada en fauor de Benito Maziel Pariente, Portugués de nacion, para que por las Prouincias del Marañon y gran Pará, que caen á la boca deste Rio, co. menzase su descubrimiento, que tampoco se puso por obra, por auerle mandado acudir ála. guerra de Pernambuco.

La de treinta y quatro, despachadaá Francisco Coelio de Carauallo, Portugués, Gouernador que entonces era del Marañon, y Pará, con espresa orden de que con toda la breuedad con personas de confiança, y si necesario fuese, el mesmo diese principio, por aquellas partes, á lc que tanto se deseaua, que nunca surtió efecto.

$\mathrm{Y}$ el presente, queriéndolo así Vuestra Magestad, tendrá feliz execucion, y en adelanle se verán cada día mayores logros de lo que tan ardientes deseos prometía. 
Lo quarto, cerrarse con esto la puerta, á que ninguno de los de los del Perú, intente arrojarse con los tesoros por la corriente deste Rio, por escusar los derechos que por Cartagena se pagan á Vuestra Magestad, y huir de los riesgos de Corsarios, que casi siempre son ordinarios poŕ aquellas partes, que es cierto lo han de pretender, ocasionados de la facilidad con que lo podrán executar: á que en ningun modo se atreuerá nadie, asegurados los puestos principales de sus entradas, como de hecho lo quedarán, con las personas que por ellos comenzaren la conquista.

Lo quinto, impedirse ha el trato, y comunicacion que tanto desean entablar los Portugueses, que asisten en la boca de este Rio, con los de su nacion del Perú, que en estos tiempos sería bien perjudicial.

$\mathbf{Y}$ en ninguna manera se atreuerán á intentarlo; si supiesen desde luego, se preuenía eon tiempo su malicia, tomando las entradas dél.

$Y$ de que intentan esta comunicacion los Portugueses de aquella costa del Marañon, y Pará, cónstame, con toda claridad, y como testigo de lo que of tratar muchas vezes entre ellos lo podré afirmar como cosa sin duda.

Lo sexto, reduciendo Vuestra Magestad á su obediencia las principales Naciones deste 
Rio, y en especial las que habitan en sus Islas, y orillas, que son muy belicosas, y que con valor ayudarán al que una vez reconocieren por dueño; en que abrá poca ó ninguna resistencia por las muchas guerras que de continuo tienen, vnas con otras, y sugeta una, lo estaràn eon facilidad las demás; podrá por el mesmo rio abaxo, mejor aun que por la mar, echar de la boca dél á qualesquiera otros, que con siniestro título la posean, y asegurar por este camino los muchos riquísimos frutos, y que de él se esperan, que esto se dilatará el gozarlo, lo que se dilate el poseerlo.

$\mathrm{Y}$ dado caso que con breuedad, como esperamos, se ponga freno, y castigue el mal mirado atreuimiento de los Portugueses, y quede desembaraçada la boca deste Rio, para que por ella se prosiga la conquista.

Començada esta ya, por las entradas de Quito, se hará más facil y necesitará de menos gastos para concluirse con felicidad.

Lo séptimo, se deue advertir con muy particular cuydado, que ya los Indios en todo el Perú, y en casi todo lo descubierto, y en especial en donde quiera que ay minas, ó otras grangerias de importancia, que dependen de su trabajo personal, como lo podemos afirmar los que auemos corrido aquellas partes, y cada 
dia van en tanta disminucion, que en breues años, por faltar ellos abrán de cesar, ó por lo menos disminuirse en gran parte, los muchos intereses que á su existencia están anexos, daño sin duda grande, y que Vuestra Magestad con esfuerço deuiera preuenir con tiempo, y remediar por todos los medios posibles, que no ay, ni se pueden imaginar otros, que tomar muy á pecho la conquista y conuersion deste nueuo mundo, donde son tantos los naturales que le habitan, que podrán poblar de nueuo todo lo despoblado del Perú: que si se sujetan al yugo del Santo Evangelio y con general paz, cesarán las contínuas guerras con que cada dia se consumen vnos á otros se aumentarán de suerte, que rompiendo por cortos los límites que al presente los encierran, será forçoso el dilatarse por más espaciosos Reynos.

$\mathrm{Y}$ quando con ellos solos se beneficiaran las muchas minas, y demás intereses que en sus Naciones ofreze la fertilidad de la tierra, se deuiera, quial otro nueuo Perú, aceptar luego su conquista, y con màs la facilidad que aquí se ofreze.

Lo octavo, si sucediese que los Portugueses que están en la boca deste rio (que todo se puede presumir de su poca Christiandad, y menos lealtad) quisiesen, ayudados de algunas 
naciones belicosas que tienen sugetas, penetrar por él arriba hasta llegar á lo poblado del Perú, ó nueuo Reyno de Granada, aunque es verdad que por algunas partes hallarán resistencia, por otras muchas la hubiera muy poca, por salir á pueblos muy faltos de gente, y en fin pisarán aquellas tierras vasallos desleales de Vuestra Magestad, que en Reynos tan distantes, pudiera solo este nombre de desleales, causar gravisimos daños. Pues si unidos con el Olandés como lo están múchos del Brasil, intentasen semejante atrevimiento, ya se ve el cuydado que pudiera dar. Y que el Olandés desde muchos años ha, y aunque procure con veras señorearse deste gran Rio, es cosa tan cierta, que no dudó afirmarlo y publicarlo, Iuan Laeth, Autor Olandés, en el libro que intituló + Vtriusque Americæ, que sacó á luz el año de trein. ta $y$ tres, donde en el libro ${ }_{17}$, cap. $\mathrm{I}_{5}$, in fine, dize estas palabras:

«Verumtamen, tan hi (scilicet Angeli, etc. Hibrini) quám nostri (scilicet Belgi) á Portugalis, é Pará venientibus, in opinato opresi, etc., fugati, non leue damnum fuerunt perpefi, ad quod refarciendum $c t$, viribus, institutum repetere, etc. vrgere satagunt.»

$\mathrm{Y}$ en el mismo libro cap. 2, dice:

«Post annumanten, I6 5 Portugali ad Paræ- 
tipam, qui fine dubio huins. magni fluminis ramus est, cæperuntün colere, vt ante diximus, etc animum, ad cæetera forté adijciente, nifi ab Angelis, etc. Belgis nostris impediantur. $\dagger$

De donde se colige bien claro, que el dila. tar el Olandés la conquista deste gran Rio de las Amazonas, de que en entrambos lugares habla el Autor, es á más no poder, y no por. que le falten deseos, y estima de lo mucho que en ejecutarlo ha de interesar.

Prevenga pues Vuestra Magestad, tan graues daños, que este su fiel vasallo le propone, y no permita se dé lugar á que algun dia lloremos pérdidas, en lo que al presente se nos ofrecen crecidas ganancias.

Finalmente, si andando el tiempo, sugeto y allanado ya el paso deste gran Rio, y aclaradas las entradas que en él ay por todo el Perú, la quisiese reducir á este viaje quantas de aquellas partes enriqueze á España, me gloria. ría yo de auer hecho á Vuestra Magestad vno de los mayores, y màs prouechosos servicios, que de vasallo se pudieran esperar; con que no solo se ahorrauan gran suma de ducados, en inmensos gastos, que serán inescusables mientras durare el tragin de Panamá, y Cartagena, que por este Rio por ser por agua, y ayudar sus corrientes serían muy moderados. 
Sino que tambien (que es lo de más consideracion) aseguraua Vuestra Magestad de vna vez sus flotas, y sin rezelos de Corsarios, ponía en salvo todos sus tesoros, por lo menos hasta llegar al Pará; de donde en veinte y quatro dias, por mar ancho, con galeones, hechos en el mesmo Rio, á todos tiempos se ponian en España, sin que enemigo alguno les pueda guardar á la salida, por ser la costa del Pará tal, que ni dos dias pueden los nauíos fuera del Rio resistir á las corrientes de la mar. Con que cesarán de vna vez los contínuos cuydados que cada dia nos causa tan peligroso y dilata. do viage como es el de Cartagena.

Todo, Señor, se remediará con lo que ten. go propuesto en este inemorial: á que solo añado, que la mayor parte del buen suceso en esta materia, será la breuedad en la execucion. $\mathrm{Y}$ si yo para algo fuere de prouecho, siempre estaré á los pies de Vuestra Magestad.

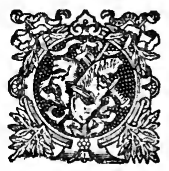




\section{INDICE DE MATERIAS}

$+000+$

Páginas.

Noticia biográfica del padre Cristobal de Acuña...................

Noticia bibliográfica de las ediciones que se han hecho de esta obra en di-

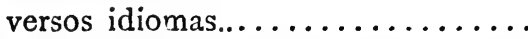

Al Excelentísimo Señor Conde Duque de Olivares............... xvir Al lector.................... $\quad x x$

Certificación del Capitán Mayor de este descubrimiento Pedro Texeira...... xxı xin

Certificación del reverendo padre comisario de las Mercedes......... Xxviı

Cláusula de la provisión real que dió la Audiencia de Quito en nombre de su Magestad para este descubrimiento.. XxIx 
I. - Noticias de este gran río... -

II. -Descubre Francisco de Ore.

llana este río. ..........

III.-Entra por este río el tirano

Lope de Aguirre. .........

IV.-Intentan otros este descubrimiento. .............

V.-Intenta Benito Maciel este descubrimiento..........

VI.-Mándasele á Francisco Coe-

llo que haga esta entrada. ...

VII. -Navegan este río dos religio-

sos, legos de San Francisco. . . VIII.-Llegan los dos religiosos al Marañón. . ........., . .

IX. - Es nombrado para la conquista Pedro de Texeira. .... .

X.-Comienza su viaje Pedro de Texeira.............

XI.-Adelántase el Coronel Beni-

to Rodríguez. ...........

XII. -Deja el Capitán el ejército en los Encabellados. . . . . . . .

XIII.-Llega el Capitán Mayor á Quito...............

XIV.-Resolución del Virrey del

Perú.............. 
XV.-El General D. Juan de Acu-

ña se ofrece á la jornada.... .

XVI.-Nombra la Real Audiencia

ai padre Cristobal de Acuña para esta jornada. ........ 30

XVII.-Salen los padres de Quito. . XVIII.-El rio de las Amazonas es el mayor del orbe......... XIX.-Nacimiento del río de las Amazonas. . . . . . . . . . XX.-Su curso, latitud y longitud. XXI.-Estrechura y fondo del río. 32 34 37 40 XXII.-Islas, su fertilidad y fruta.. . XXIII.- Géneros de bebidas que usan. ..............

XXIV.-Frutas que tienen. ....... $\mathrm{XXV}$.-Pescados de este río y del Pegebuey............ 50

XXVI.-Tortugas del río y cómo las guardan........... 52 XXVII.-Modos de pescar que usan. 42 44 46 48 52
55 $\therefore$ VIII.-Cazas del monte y aves de que se sustentan. ....... $5^{8}$ XXIX.-Clima y temple del río.... $6 \mathrm{I}$ XXX.-Disposición de la tierra y drogas medicinales. ........ XXXI.-Maderas, aderezos para na- 
XXXII.-Cuatro géneros de cosas provechosas que hay en este río. . 68 XXXIII.-De otros géneros de estima que aquí se hallan........ $7 \mathbf{r}$ XXXIV.-Riquezas de este río. . . . . . 72 $\mathrm{XXXV}$.-Son cuatro mil leguas de circuito lo descubierto. . . . . . . . XXXVI.-Multitud de gente y diferentes naciones. ........... XXXVII.-Armas de que usan los in-

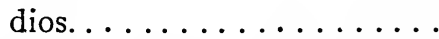

XXXVIII.-Su comercio es por el agua en canoas........... 82 XXXIX.-Las herramientas que usan. XL.-De sus ritos y Dioses que adoran............ 86

XLI.-Un indio se hacía Dios.. . . . 90 XLII.-De los hechiceros que hay . XLIII.-Son estos indios de apacibles naturales.......... XLIV.-Trátase en especial de las cosas del río y de sus entradas.

XLV.-De tres entradas que hay por el nuevo reino......... 99 XLVI.-Otras entradas,. . . . . . r ro2 
XLVII._Otras entradas á este río. . . 105 XLVIII.-Río de Napo,. . . . . . . . 107

XLIX.-Aquí mataron al Capitán $\mathrm{Pa}$ lacios............ $\quad$ 09

L.-Aquí quedó la armada portuguesa, provincia de los Encabellados........... III

$=$ Río de Tunguragua........ II4 LI.-Provincias de los aguas. . . I I I5 LII.-Uso de los esclavos que cautivan. ........... II9

LIII.-Sitio frío en que se podrá coger trigo........... 122 LIV.-Río Putumayo ynaciones que en él y en Yetaú hay....... I 24 LV.-Fin de la provincia de los Aguas y róo del Cuzco. ..... I27 LVI.-Provincia donde se halló oro. $\quad$ I 29 LVII.-Minas de oro. . . . . . . . I I2 LVIII.-Usan orejas y narices agujereadas. . . . . . . . $\quad$ r 34 LIX.-Entrada á las minas de oro. $\quad{ }^{36} 6$ LX.-Lago Dorado. ......... I $_{3} 8$ LXI.-Provincia de Yoriman.... I 40 LXII.-Un pueblo de más de una legua de largo.......... $\mathbf{1 4 2}$ LXIII.-Río de los Gigantes. . . . . I 44 
Números.

Páginas.

LXJV.-Río Basururú y sus naciones.

LXV.-Rio Negro.. . . . . . . . . I50

LXVI. - Intentan los portugueses entrarse por el río negro....... $\quad{ }_{55}$

LXVII.-Requerimiento hechoal ejército.............. $15^{8}$

LXVIII.-Prosigue el viaje y del río de la Madera............ I65 LXIX.-Isla grande de los Tupinambás............... ${ }^{6} 6_{7}$

LXX.-Noticias que dieronlos Tupinambás............ I 70

LXXI.-Dan noticias delas Amazonas. $\quad$ I 73 LXXIF.-Río de las Amazonas.. . . . . $\quad$ I76 LXXIII.-Estrechura de todo el río.. . $\quad$ I 79 LXXIV.-Río y nación de Tapajosos. . $\quad$ I82 LXXV.-Opresión que hicieron los portugueses........... $\quad \mathrm{I}_{3}$ LXXVI.-Curapatuba. . . . . . . . I 88 LXXVII._Río Ginipape. . . . . . . . 190 LXXVIII.-Río Paranaíba. . . . . . . . 193 LXXIX.-Río Pacaxa.. . . . . . . . . $\quad 194$ LXXX._Población de Conmuta. . . . $\quad 196$ LXXXI._Río de los Tocantines.. . . . 197 LXXXII._El Pará. . . . . . . , . . . . $\quad$ r99 LXXXIII.-Entra en el mar el río de las Amazonas............ 
INDICE

$=$ Memorial presentado en el real consejo de las Indias, sobre el dicho descubrimiento, después de la revelión de Portugal.... 205

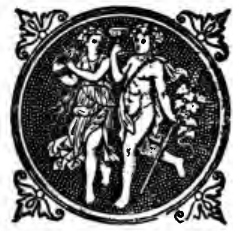




\section{INDICE}

POR ORDEN ALFABÉTICO

DE TODO LO CONTENIDO EN ESTA OBRA

$$
+0+
$$

Págin as.

Abundancia de algodón.. . . . . . . . . Abundancia de cacao............ 68 Abundancia de pesca en el Amazonas. . $\quad 35$ Aderezos para navíos.. .......... ${ }_{67}$ Aldea de Conmutá. . . . . . . . . . . . 196 Alfonso de Miranda.. . . . . . . . . . 7 Altura de los árboles.. . . . . . . . . 66 Amazonas; noticias que dieron de ellas los Tupinambás............. $\quad 173$ Amazonas; sus costumbres......... $\quad 174$ Amazonas; valor que tienen y otras cosas peregrinas............ $\quad$ r 77 
Aprecio en que tienen á sus hechiceros. 92 Armas que tienen los indios. ........ 79 Azúcar que hay. ........... $\boldsymbol{6}_{9}$

Bebidas que hacen. ............ 46

Benito Maciel Pariente.. . . . . . . . . . 8

Benito Rodríguez de Olivera. ....... 20

Brevedad que se ha de tener en comenzar esta conquista.............

Buen temple del río.............. 218

Cáliz que se halló en poder de los Tocan-

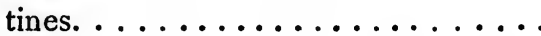

Carlos V manda dar tres navios á Orellana...................

Cédulas dadas para el descubrimiento de este río............. 2 I 2

Cerros del río............. 64

Cerros de sal de piedra......... I 72

Certificación del padre comisario de las Mercedes............... xxvir

Certificación de Pedro Texeira...... xxıı

Clases de frutas que tienen. ....... 48

Cláusula de la Audiencia de Quito.... xxix

Cojen las tortugas en gran abundancia.. $\quad 54$ Comercio y cómo lo hacen. ....... 82

Cómo conservan las tortugas........ 52 Cordilleras de Guanuco de los Caballeros.................... 
Costumbre que tienen los Aguas deaplastarse la cabeza. . . . . . . . . . .

Crueldades de los portu gueses con los Tapajosos.............. $\quad \mathbf{1 8 5}$

Curipunás y zurinas y sus habilidades. . . $\quad 145$ Curso, latitud y longitud de este rio... . 40 Curuziraris y géneros que fabrican.... I 30 Dedicatoria del autor. ......... xvII

De la poca dificultad que pondrían para creer en Dios. . . . . . . . . . . . 95

Del poco trabajo para cazar y pescar... $\quad 59$

Desbarátanse todos los planes....... 9

Desemboca en el mar el rio de las Amazonas............... $20 \mathrm{r}$

De sus ritos. .............. 86

Dioses que adoran........... 87

Diversos géneros de herramientas. . . . 85

División del río de las Amazonas...... $\quad 194$

Don Juan Vázquez de Acuña ofrece hacer este descubrimiento á su costa. ..... Dos religiosos descubren este río...... Dos religiosos y seis soldados, llegan milagrosamente á Pará. ......... I4

Drogas medicinales que hay. ....... 65

Ediciones de esta obra......... Ix

$\mathrm{El}$ autor al lector............. $\mathrm{xxr}$

El 28 de Febrero de 1637 sale del Pará 
la armada portuguesa........... 18

El r6 de Febrero de 1639 , sale la armada de Quito................. El I 2 de Diciembre de r639 llega á Pará la armada................

El capitán mayor manda proseguir el viaje....................

El conde de Chinchón resuelve que Te. xeira vuelva rio abajo...........

El Eufrates comparado con el Amazo-

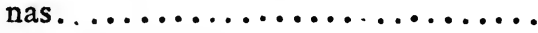

El Ganges comparado con el Amazonas.

El mayor estrecho del Amazonas...... 32 El nuevo reino de Granada..........

El padre Cristobal de Acuña se ofrece para ir á la jornada............

El padre Francisco de Fuentes nombra para la jornada á dos de su religión. . El Pegebuey .................

El rio de las Amazonas es el mayor del mundo...................

Embarcaciones que tienen.......... Encabellados, por qué los llamaron ası y de sus armas y guerras.......... Encabellados y portugueses......... Entierro de sus difuntos.......... 93 Entrada por la ciudad de Archidona. - $\quad 130$ 
Entradas á este río............. I02

Esclavos que cautivan los Aguas y uso de ellos...................

Estrechura de todo el río........... I9 I 79

Flechas de pescar............ $\quad 5^{6}$

Francisco Coello de Caravallo....... 9

Fray Andrés de Toledo........... I I

Fray Domingo de Brieba.......... I 2

Frío que sienten los que tocan el Peraque.....................

Fríos y donde los hace........... 122

Frutas de las islas del Amazonas.... . $\quad 45$

Géneros de caza que hay.......... $\quad 5^{8}$

Géneros de estima que se hallan en el

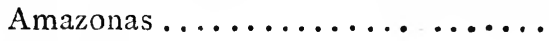
$7 \mathrm{I}$

Gran Pará................. 199

Guayazis, nación de enanos......... I 70

Guerras de los Aguas con los Cnrinas y

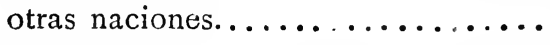

Habilidades de los naturales que habi-

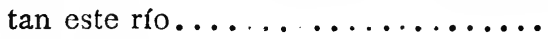

Herramientas que tienen..........

Holandeses y cómo se apoderaron de la

Guayana................. $\quad \mathbf{1}_{4} 8$

Indios Aguas, por qué son llamados así. I I5 Indios Aguas, su gobierno y costumbres. I 16 Indios Tupinambás y su isla......... I I67 
Industria de Texeira para que no le abandonasen................ I9

Inmensas riquezas que hay......... 73

Isla del Sol.................. 200

Islas que hay en este río........... 44

Jacome Raimundo de Noroño tiene noti-

cia del viaje de los dos legos....... José de Villamayor............... Lago Dorado y donde debe hallarse... Leguas que ocupa lo descubierto...... Lengua que hablan los Tupinambás.... Lope de Aguirre desemboca en la isla de la Trinidad, donde le quitan la vida.....................

Los cofanes matan al padre Rafael Fe-

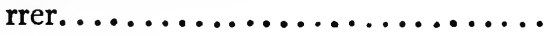
I 5

Los naturales son muy inclinados á la embriaguez ............... Los holandeses infestaban las costas... 47 Los portugueses atacan á los Tapajosos. Los portugueses dejan una cruz á los in-

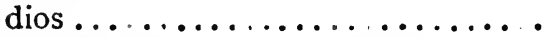
Los portugueses quieren rebelarse..... Los Tapajosos atacan á los portugueses. Maderas de este río.............. Maderas para canoas. ............ Memorial presentado en el Consejo de

88 r 56 I 86 68 83 
Páginas.

las Indias................ 205

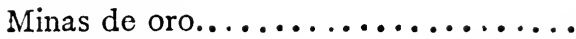

Minas de oro y plata de que hay noticia.....................

Modos diversos de pescar.......... Mutayos, tributarios de los Tupinambás. Nación de los Curuziraris............ Nación de Yorimán y sus naturales..... Naciones que hay en lo descubierto.... No hay aires corruptos en este río .... No son caribes los indios Aguas....... Noticias del Padre Acuña......... . Omaguas, su significado.......... Orellana descubre este río........... Orellana tiene que retirarse por la costa de Caracas .................. 72 55 171 129 I 40 77 63 I 20 $\mathrm{V}$ 125 2 3

Oro y donde se hallo............ I 30 Paraguaxo, sierra de rica pedrería.... $\quad$ I 89 Partes porque se puede entrar en este río. 97 Pedrería, dónde se encuentra y noticia que dieron los indios de ella....... I 89 Pedro de Acosta Jabela es nnmbrado cabo de todos................ 22

Pedro de Orsua es muerto á traición por Lope de Aguirre.............. 4 Pedro de Texeira es nnmbrado para esta conquista.................. 
Pescado llamado Peraque.......... 56

Pesca y caza en el rio Napo......... 103

Pesca y caza en el río.Yetáu........ I 26

Población de Anete, donde mataron al capitán Palacios.............. $\quad 109$

Poco coste para hacer ingenios...... 79

Primera entrada á este río.......... 99

Profundidad del Amazonas......... 43

Provincias del río Negro.......... $\quad \mathbf{I}_{52}$

Pueblo mayor deste río.......... $\quad \mathbf{I}^{2}$

Regocijos en Quito por la llegada de Te-

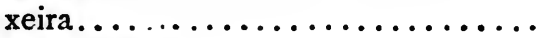

Requerimiento hecho al ejército...... I 59 Rio Aguraico................. 109

Río Araganaruba y sus naciones...... $13^{8}$

Rio Basururú y sus naciones ... . ... $\quad 147$

Río Catua................. I 18

Río Cuchiguará y sus pobladores...... I I44

Río Curupatuba............... . $\quad$ I 88

Río de la Coca............... 108

Rio de la Madera y sus naciones...... $\quad 166$

Rio de las Amazonas, nombrado por error Marañón.............. I

Río del Cuzco y por dónde entra en el de las Amazonas............. $\quad 128$

Río de los Tocantines........... $\quad 197$

Rio de Napo y donde tiene su origen... 107 
Páginas.

Río Ginipape y sus provincias......... I 40 Río Marañón y donde se junta con el de las Amazonas................. 106 Río Negro, por qué le llamaron así los portugueses................ I5I Río Pacaxa.................. I94 Río Paranaíba y sus poblaciones....... $\quad$ I93 Río Putumayo y de dónde desciende... I $\quad$ I 4 Ríos tributarios del Amazonas....... 4I Río Tapi................... I36

Río Tumguragua, corre por los Maynas con nombre de Marañisn.......... II 4 Río Urixamina............... I79 Río Yetaú y sus naciones.......... I25 Río y nación de Tapajosos......... I I $8 \mathbf{I}$ Riquezas que ofrece este río........ 202 Sal que tienen .............. $5^{\mathbf{I}}$ San Francisco de Quito............ I I Segunda entrada á este río......... roo Sierra llamada Paraguaxo y pedrerías que en sí encierra........... I 89 Son las tortugas muy grandes........ 53 Son mansos y apacibles estos indios... 94 Tabaco de este río.............. 69 Tercera entrada á este río........... Ior Trigo y dónde se podrá coger........ I $\quad$ I23 Un indio pide que le den un Dios..... 87 
Un indio quiere que le enseñen á Dios. . 90 Usan flechas envenenadas.......... 8r Uso que hacen de las armas....... . 80 Variedad en el clima............ 62 Vecindad de las naciones que habitan en las riberas.................. Verdadero nacimiento del río de las Amazonas ................. $3^{8}$ Vertientes que descienden hacia el Amazonas ................... 73

Vicente de los Reyes intenta cste descubrimiento................ 6

Yumaguaris y su significado......... I I33 Yupura, río que da entrada al del Oro.. $\quad$ I36 Zarzaparrilla, estima que hacen de ella. $\quad 7 \mathbf{I}$ 



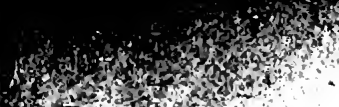

\section{.}

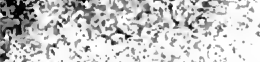

4 rof

15tord

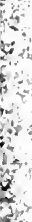

$\forall$,

यो $A$ का

$\rightarrow \vec{a}=0$

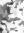

2

$\lim _{i=1}$

40

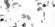

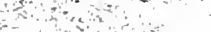

$\therefore$ 



\section{TOMOS PUBLICADOS}

I Xerez, Conquista del Perí. (1534.)

II Acuña, Nuevo descubrimicnto del gran rio de las Amazonas. (164r.)

\section{PARA SALIR EN BREVE}

III Rocha, Origen de los indios occidentales del Perú, México y Santa Fé y Chile. (r68r.)

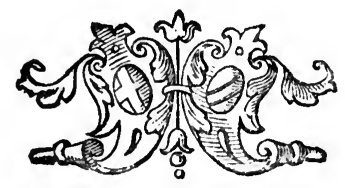


Se acabó de reimprimir este volumen en Madrid y en la imprenta de Juan Cayetano García, calle de Atocha. número ciento cincuenta $y$ uno, á treinta dias del mes de Abril de mil ochocientos no. venta $y$ uno

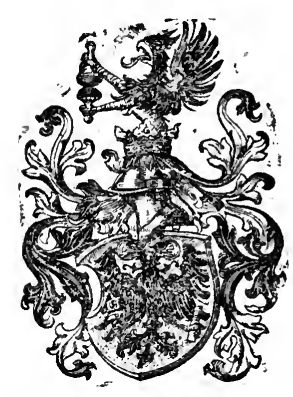




\section{$\frac{3}{3}$

Stis

Q.2.5.

syisis: $4 \vec{i} ;$

and 
Hifint W.

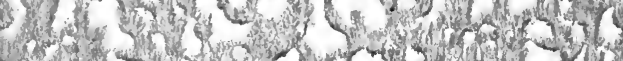

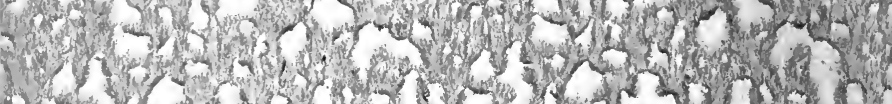

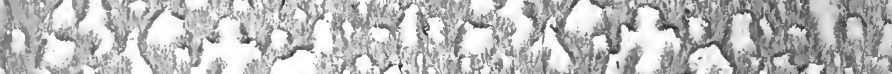

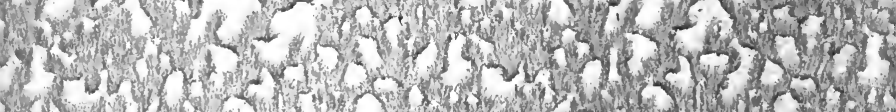

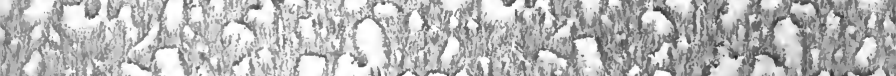
211.

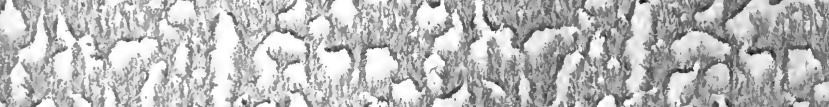

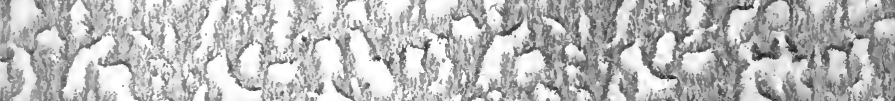

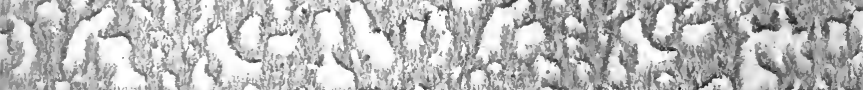

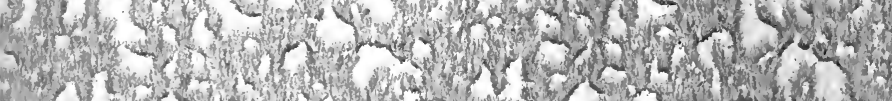

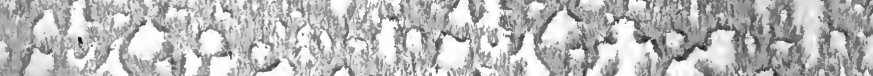

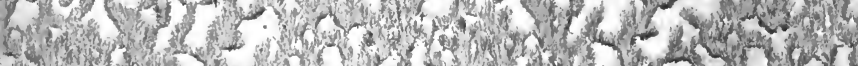

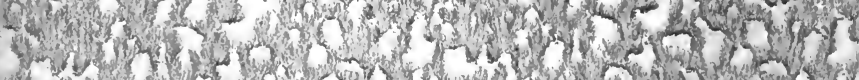

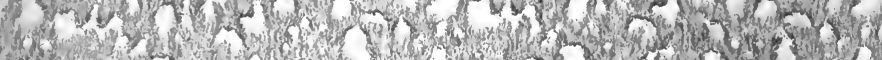

(1)

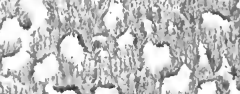

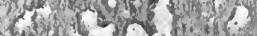

(1)

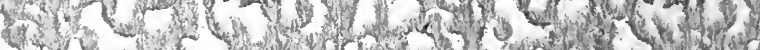

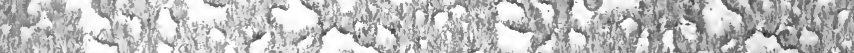

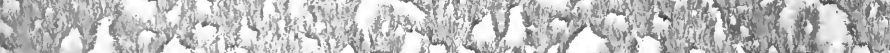
(1) 3
3

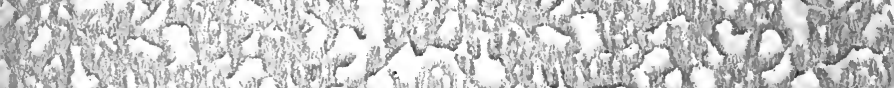

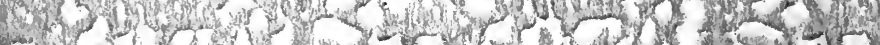




\section{UNIVERSITY OF TORONTO LIBRARY}




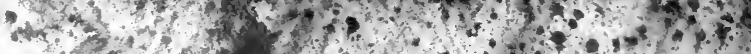

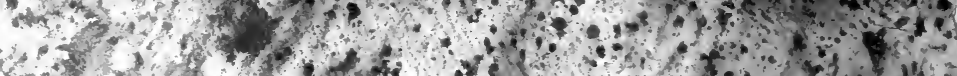

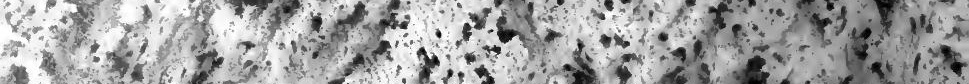

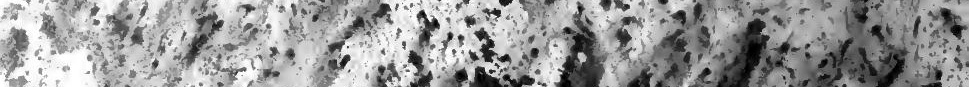

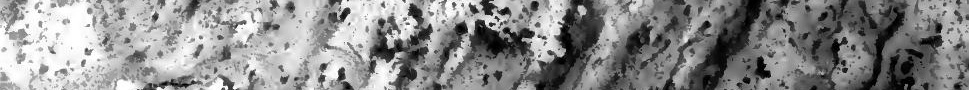

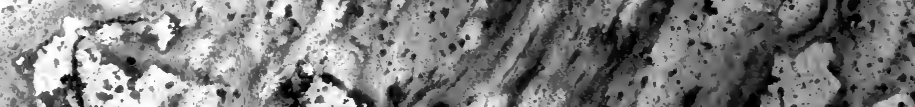

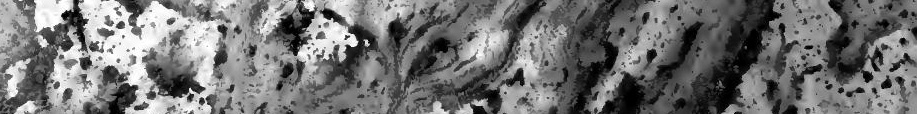
- -1 .

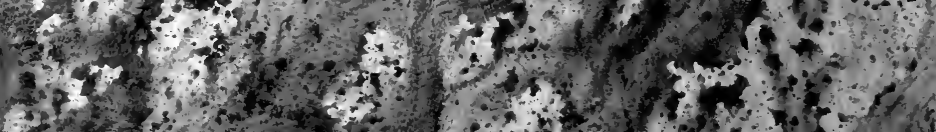

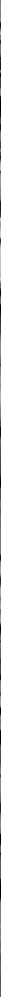

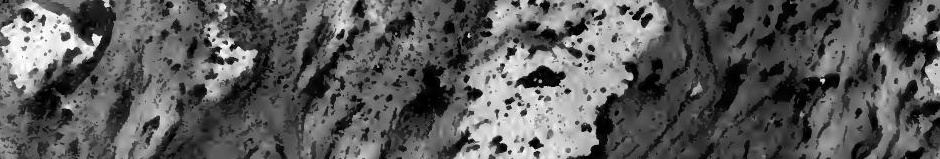
. s.1.
(30., in) on

$-1,340$

1,9100

$4(2)$

- 13

(2) $\rightarrow$

mind

$3 x$

a. 3

artin

is 